Universidade de São Paulo

Instituto de Física

\title{
Mecânica Estatística de sistemas complexos: crescimento de tumores com diferenciação e mobilidade celular.
}

\author{
Paula Sampaio Meirelles
}

Orientadora: Profa. Dra. Carmen Pimentel Cintra do Prado

Dissertação de mestrado apresentada ao

Instituto de Física para a obtenção do título de

Mestre em Ciências.

Banca examinadora:

Profa. Dra. Carmen Pimentel Cintra do Prado (IFUSP)

Prof. Dr. Marcelo L. Martins (UFV)

Prof. Dr. Airton Deppman (IFUSP)

São Paulo - 2010 
FICHA CATALOGRÁFICA

Preparada pelo Serviço de Biblioteca e Informação do Instituto de Física da Universidade de São Paulo

\begin{tabular}{|l|}
\hline Meirelles, Paula Sampaio \\
\hline Mecânica estatística de sistemas complexos: \\
crescimento de tumores com diferenciação e mabilidade \\
celular. - São Paulo, 2010. \\
Dissertação (Mestrado) - Universidade de São Paulo. \\
Instituto de Física, Depto. de Física Geral \\
Orientador: Profa. Dra. Carmen Pimentel Cintra do \\
Prado \\
\hline Área de Concentração: Física \\
Unitermos: 1. Mecânica Estatística; 2. Física \\
Computacional; 3. Fenômenos Biológicos \\
USP/IF/SBI-034/2010 \\
\hline
\end{tabular}


À minha mãezinha que tanto amo, Nevinha 


\section{Agradecimentos}

Esse trabalho é apenas um tímido estudo do ponto de vista científico, porém, para mim, ele representou uma grande evolução pessoal, de fato, um divisor de águas! Algumas pessoas foram essenciais nessa minha longa e tortuosa caminhada e gostaria de aproveitar o espaço para agradecer a todos:

Minha mãezinha, Nevinha, por toda dedicação e amor. Certamente, você é um grande exemplo para mim de força, maturidade e ternura. Agradeço todo o suporte, principalmente nas horas mais críticas, e por sempre acreditar em mim e na minha "vocação " científica;

Meu pai Paulo, por despertar em mim desde muito cedo a paixão pela ciência e por me fazer entender que independente dos rótulos que damos (física, química ou biologia), no fundo, é sempre ela : a Natureza!;

Minha irmã Daniela e ao meu cunhado Marcelo por toda força e estímulo que me deram aqui em Sampa e pelos sábios conselhos, além dos vinhos maravilhosos também;

Todos os meus numerosos e incríveis parentes! A distância só me fez perceber o quanto eu os amo! Especialmente, tio Nelinho, tia Tânia, Camila, Catia, André e Manuela, por considerá-los como minha segunda família. Todo o apoio que vocês deram a mim, a 
minha mãe e a minha irmã foi muito grandioso e jamais esquecerei.

Professora Carmen, pela orientação;

Professor Bosco, pelas discussões científicas, pelo ânimo contagiante e pelos inúmeros cafezinhos!

Telma, pelo exemplo de pesquisadora, pelas aulas de biologia, por me mostrar, na prática, como se cultiva células tumorais, pela amizade e por todo o carinho;

Meus professores na pós graduação Renata Funchal, Tânia Tomé e, em particular, ao professor Silvio Salinas, por quem tenho uma enorme admiração;

Meus supervisores de estágio, professora Teresa Lamy e professor Mikiya Muramatsu pela linda dedicação ao ensino de Ciência;

Todos os meus colegas de mestrado, especialmente ao Tiaguito pelas conversas científicas "impactantes" e pela amizade;

Todos os meus colegas de departamento: Silas, Danilo, Antônio Mário, Helder, Eduardo, Masayuki, Evandro, Alexei, William, David, Rodrigo, Renato, Leandro, Jonatas, Alex e Bruno, por fazer o ambiente ser tão discontraído e saudável;

Lucas, Áttila e Henrique pela grande ajuda com os programas e scripts;

Paula Fernanda, pelo apoio, amizade, leitura da dissertação, e pelos inúmeros e merecidos "puxões de orelha";

Maicon Saul, "meu mestre", pela ajuda computacional, por me tirar do "analfabetismo digital" e me abrir as portas para o incrível mundo dos shell scripts; além das instigantes conversas sobre política e filosofia, minha eterna gratidão!

Minha talentosíssima amiga Mariana, pela amizade de tantos anos, pelas exaustivas e excitantes conversas, pelo suporte emocional, por todos os filmes e comidinhas! Nossa relação é muito 
importante para mim!

Meu amigo Sérgio, por participar desde da etapa da minha partida de Salvador até dos meus grandes "dramas" em Sampa e me mostrar que não são tão grandes "dramas" assim! Realmente, um grande amigo!

Minha amiga Darlene pelas conversas altamente filosóficas que muito me acrescentam;

Aos funcionários Dirce, Fátima, Silvana, Valdir, Márcia e seu Wilson pela simpatia, pelo suporte e carinho;

Ao ACBEU (Salvador) e ao Goethe Institut (São Paulo) pelas bolsas concedidas;

E finalmente, não menos importante, ao $\mathrm{CNPq}$ pelo suporte financeiro durante o mestrado. 
No final da graduação, li um livro de um grande físico que me influenciou muito e só confirmou o que eu já acreditava: a Ciência não tem fronteiras! Certamente, por causa dele e da minha enorme fascinação pelo fenômenos vivos é que me envolvi nesse projeto. Nada mais natural, então, que começar essa dissertação com um trecho desse livro que se encaixa perfeitamente na questão do câncer:

"O desdobramento de eventos no ciclo de vida de um organismo exibe uma admirável regularidade e ordem, sem comparação com qualquer coisa que encontramos na matéria inanimada. Descobrimos que esse ciclo é controlado por um grupo de átomos supremamente bem ordenado, que representa apenas uma fração muito pequena da soma total de átomos em toda célula. Além disso, do ponto de vista que formulamos acerca do mecanismo de mutação , concluímos que basta o deslocamento de uns poucos átomos apenas dentro do grupo de 'átomos dirigentes' da célula germinativa para fazer aparecer um alteração bem definida nas características de larga escala do organismo." Trecho extraído do livro "O que é vida?" de Erwin Schrödinger. 


\section{Resumo}

O câncer (neoplasia) é uma das principais causas de mortalidade no mundo. Apesar dos grandes avanços no diagnóstico e nas formas de tratamento, ele ainda representa um enorme desafio para os pesquisadores de muitas áreas. Recentemente houve uma importante descoberta que poderá fornecer um paradigma completamente diferente no entendimento de como o câncer se inicia e cresce, com eventualmente profundas consequências nas formas de tratamento. Essa descoberta diz respeito à presença de células tronco adultas em tumores e seu possível papel no surgimento e crescimento destes. Propomos nesse trabalho um modelo matemático que considera a presença de células com propriedades de (a) auto renovação , (b) diferenciação e (c) mobilidade, características das células tronco. O modelo proposto é um autômato celular probabilístico com atualização assíncrona em uma rede. Cada elemento da rede pode estar vazio ou conter uma célula tumoral. Há dois tipos de células: as células rotuladas como do tipo 2 que são aquelas associadas com as células tronco tumorais e aquelas rotuladas como do tipo 1 que são as células diferenciadas, somente com capacidade de reprodução. A taxa de reprodução de cada célula é definida como uma função de sua vizinhança e tipo. Diferentes taxas de reprodução foram usadas nas simulações e as células do tipo 2 podem diferenciar-se ou 
mover-se. Os resultados das simulações mostram como a motilidade das células 2 e as taxas de reprodução de ambos os tipos de células influenciam os padrões morfológicos do tumor. Também investigamos uma possível transição de fase que pode estar relacionada à metástase. Essa transição de fase representa algo de grande interesse biológico, uma vez que a metástase é o mecanismo mais importante que leva o organismo à óbito. Compararemos nossos resultados com dados experimentais dos colaboradores Nascimento TL et al [1] da UNIFESP- Escola Paulista de Medicina. 


\section{Abstract}

Cancer (neoplasia) is one of the most dangerous diseases and one of the main cause of mortality around the world. Despite the great advances in diagnosis and treatment, it still represents a huge challenge to researchers of many areas. Recently there was a strinking discovery that may give rise to a complete different paradigm in the understanding of how cancer starts and grows, with eventually profound consequences in the forms of treatment. It is related to the finding of adult stem cells in tumors, and its possible role in the birth and growth of them. We propose in this work a mathematical model that takes into account the presence of cells with the properties of (a) self renewal, (b) differentiation and (c) mobility, characteristics of stem cells. The model developed is a probabilistic cellular automaton with asynchronous update set in a grid. Each element of the grid may be empty or contain a tumor cell. There are two types of cells: the cells labeled as type 2 are those associated with cancer stem cells and those labeled as type 1 are differentiated cells only capable of reproducing. The reproduction rate of each cell is defined as a function of its neighborhood and its type. Different rates of reproduction have been used in the simulations, and type 2 cells may differentiate and some motility. Our simulation results show how the motility of cells 2 and the reproduction rates of both types of cells influence the morphological patterns of tumor. We have also investigated a possible phase transition that may be related to metastasis. This phase transition represents something of great biological interest because metastasis is the most important 
mechanism that leads to death. We will compare our results with experimental data from collaborators Nascimento TL et al [1] in UNIFESP-Escola Paulista de Medicina. 



\section{Sumário}

Agradecimentos

Resumo i

Abstract iii

1 Introdução 1

2 Introdução à biologia do câncer 5

2.0.1 A formação tumoral . . . . . . . . . . . 5

2.0.2 Uma nova hipótese sobre a origem dos tumores 14

2.0.3 Modelagem matemática de tumores . . . . . . 22

3 Descrição do modelo numérico 27

3.1 Introdução . . . . . . . . . . . . . . . . 27

3.2 Estrutura do programa . . . . . . . . . . . . . . . 29

3.2.1 Motilidade das células tipo 2 (difusão) . . . . 31

3.2 .2 Reprodução das células . . . . . . . . . . . . 39

3.3 Diagrama do programa principal . . . . . . . . . . 43

3.4 Considerações gerais . . . . . . . . . . . . . 46

4 Resultados das simulações $\quad 49$

4.0 .1 Introdução . . . . . . . . . . . . . . . . . . 49

4.0.2 Modelos Nulos . . . . . . . . . . . . . . 53

4.0.3 Estudo do Modelo Completo . . . . . . . . . 64

4.0.4 Transição de fase metástase - não mestástase . 83

vii 
4.0.5 Resultados experimentais . . . . . . . . 95

5 Considerações Finais $\quad 97$

$\begin{array}{ll}\text { Referências Bibliográficas } & 99\end{array}$ 


\section{Capítulo 1}

\section{Introdução}

O câncer é um fenômeno que ocorre em organismos pluricelulares devido ao acúmulo de diversas mutações genéticas em um dado conjunto de células. Através desse processo, as células mutadas adquirem a capacidade de se reproduzirem independentemente da sinalização bioquímica do microambiente em seu entorno. A reprodução acelerada dessas células e a capacidade de invadir outros tecidos e órgãos acaba por afetar a arquitetura ordenada do organismo, comprometendo certas funções vitais e levando-o a óbito.

Muito tem sido feito no sentido de entender o câncer e, assim, desenvolver uma estratégia para sua cura e prevenção . Visando uma abordagem mais interdisciplinar em torno desse problema, biólogos, médicos, matemáticos e físicos se uniram na busca do entendimento da dinâmica evolutiva do câncer.

O crescimento de um tumor é um fenômeno complexo, que depende de vários fatores, em particular da forma como as células tumorais se reproduzem e de como elas se movem no tecido hospedeiro. Parte da dificuldade em estudar e compreender os mecanismos que definem essa dinâmica está na dificuldade de descrever e classificar 
tumores de uma forma mais quantitativa. O emprego de diversos modelos matemáticos e simulações computacionais no tratamento quantitativo do câncer é algo muito recorrente na literatura. Por ser um fenômeno que envolve muitas escalas, existe uma infinidade de modelos que utilizam as mais diversas técnicas computacionais para representar a formação tumoral $[2,3,4,5,6,7]$.

Atualmente dentro do panorama da pesquisa do câncer, a hipótese de que as células tronco adultas podem ser as células iniciadoras e mantenedoras dos tumores é algo que está trazendo uma profunda mudança no paradigma empregado na descrição desse fenômeno. Se confirmadas essas hipóteses, pode haver uma mudança importante nas formas de tratamento, que até hoje são desenvolvidas visando exterminar todas as células tumorais, não combatendo especificamente as chamadas células tronco tumorais. Estas são muito mais resistentes à tratamentos quimioterápicos convencionais, o que aponta para uma urgência de novos estudos sobre o papel dessas células na dinâmica de crescimento tumoral.

É exatamente dentro dessa nova perspectiva biológica que se propõe, nesse trabalho de mestrado, um modelo computacional que contempla a presença de células com características de células tronco entre as células do tumor. O modelo é um autômato celular probabilístico com dois tipos celulares, denomidadas daqui para a frente de tipo 1 e tipo 2 . As do tipo 2 estão associadas às células tronco tumorais e as do tipo 1 são associadas às células tumorais 'normais'. A pesquisa desenvolvida consistiu em analisar como determinadas regras locais para a reprodução e a motilidade das células tipo 2 afetavam a forma macroscópica dos tumores. Foi descoberta uma possível transição de fase nesse modelo que pode estar relacionada com a possibilidade de ocorrência de metástase. 
O projeto contou com a colaboração de um grupo de pesquisadores do Laboratório de Biofísica e Imuno e Parasitologia da Universidade Federal de São Paulo (Escola Paulista de Medicina, UNIFESP) envolvidos com a parte experimental do crescimento de tumores. A interação com esses pesquisadores foi o que motivou a elaboração desse modelo que, como já foi dito, considera essa nova hipótese biológica, que é a da existência de células tronco em tumores. Apesar de não se comparar quantitativamente os resultados das simulações com os experimentos realizados, o modelo aponta resultados bem promissores do ponto de vista biológico, como a existência da possível trasição de fase.

Esse trabalho se divide em quatro capítulos. No capítulo 2 encontra-se uma descrição resumida do que se conhece sobre o câncer, assim como o surgimento da hipótese sobre a tumorização das células tronco adultas e seu papel no desenvolvimento dos tumores. No capítulo 3 discute-se detalhadamente toda a construção do modelo numérico, suas justificativas biológicas e também a sua implementação. No capítulo 4 são apresentados todos os resultados das simulações realizadas com o modelo. Finalmente, no capítulo 5, são esboçadas algumas perspectivas futuras e resumidas as conclusões obtidas, que se espera possa dar uma contribuição ao entendimento desse complexo processo biológico. 



\section{Capítulo 2}

\section{Introdução à biologia do}

\section{câncer}

\subsubsection{A formação tumoral}

A possibilidade das células de um organismo pluricelular reproduzirem-se é de fundamental importância para a sua sobrevivência. A reprodução de uma célula é um processo controlado pelo organismo através de sinalizações químicas, de forma a manter a homeostase ${ }^{1}$ dos seus tecidos e órgãos. A falha nesse controle de reprodução celular acarreta a formação de uma massa amorfa sem função, chamada de tumor ou neoplasia (no caso de tumores sólidos), capaz de destruir o organismo e levá-lo a óbito.

Em qualquer célula, a replicação do genoma e sua consequente divisão em células geneticamente idênticas pode ser divida em quatro estágios distintos do seu ciclo celular, denominados G1, S, G2 e M. Esses estágios são muito bem estabelecidos e conhecidos pela comunidade científica [8].

\footnotetext{
${ }^{1}$ Homeostase é a propriedade que os seres vivos tem de regular o seu ambiente interno de modo a manter uma condição estável. Isto é feito através de múltiplos ajustes em um equilí brio dinâmico, controlados por mecanismos de regulação interrelacionados.
} 
Na fase G1 a célula passa por mudanças bioquímicas que a preparam para a fase seguinte $\mathrm{S}$, em que um novo DNA é sintetizado. A duração dessa fase parece depender de certos elementos presentes na matriz extracelular, tais como nutrientes e fatores de crescimento mitogênicos (que favorecem a mitose ou divisão celular).

$\mathrm{Na}$ fase dita S, a célula produz uma cópia do seu material genético e, então, passa para a segunda fase preparatória para divisão, conhecida como G2, em que recebe outra preparação bioquímica para a mitose.

$\mathrm{Na}$ fase $\mathrm{M}$, que diz respeito a mitose propriamente, o DNA original e o replicado são condensados em pequenos pacotes, conhecidos como cromossomos, e separados tal que cada célula-filha receba um genoma.

Para reduzir os riscos de mutações genéticas nocivas durante o processo de reprodução, são realizadas várias checagens bioquímicas ao longo de todo o ciclo celular. Isso garante que o DNA da célula esteja completamente duplicado e pronto para a mitose e impede que as células adquiram anormalidades genéticas tão comuns em células tumorais.

Uma célula pode, seguindo a fase da mitose, entrar na fase preparatória G1, dividir-se novamente e seguir multiplicando-se desde que existam condições químicas favoráveis à sua divisão.

Caso a célula não receba tais estímulos químicos, ela entra em um estado quiescente, conhecido como G0. Esse é o estado que se encontra a maioria das células de um organismo, marcado pela ausência de fatores mitogênicos ou nutrientes que permitem a passagem desse estágio para a fase G1. A figura 2.1 ilustra esquematicamente as fases do ciclo celular anteriormente descritas.

Como as células estão ligadas ao meio extracelular e às outras 
células vizinhas a ela, há uma intensa comunicação bioquímica da célula com seu entorno, e é essa comunicação bioquímica que leva a célula a reproduzir-se quando necessário e a parar de se reproduzir quando o número de células exigidas para a formação ou manutenção de algum tecido ou órgão é suficiente. Em experiências in vitro, manipulando-se a presença externa de fatores de crescimento é possível fazer as células continuarem ou não no ciclo reprodutivo.

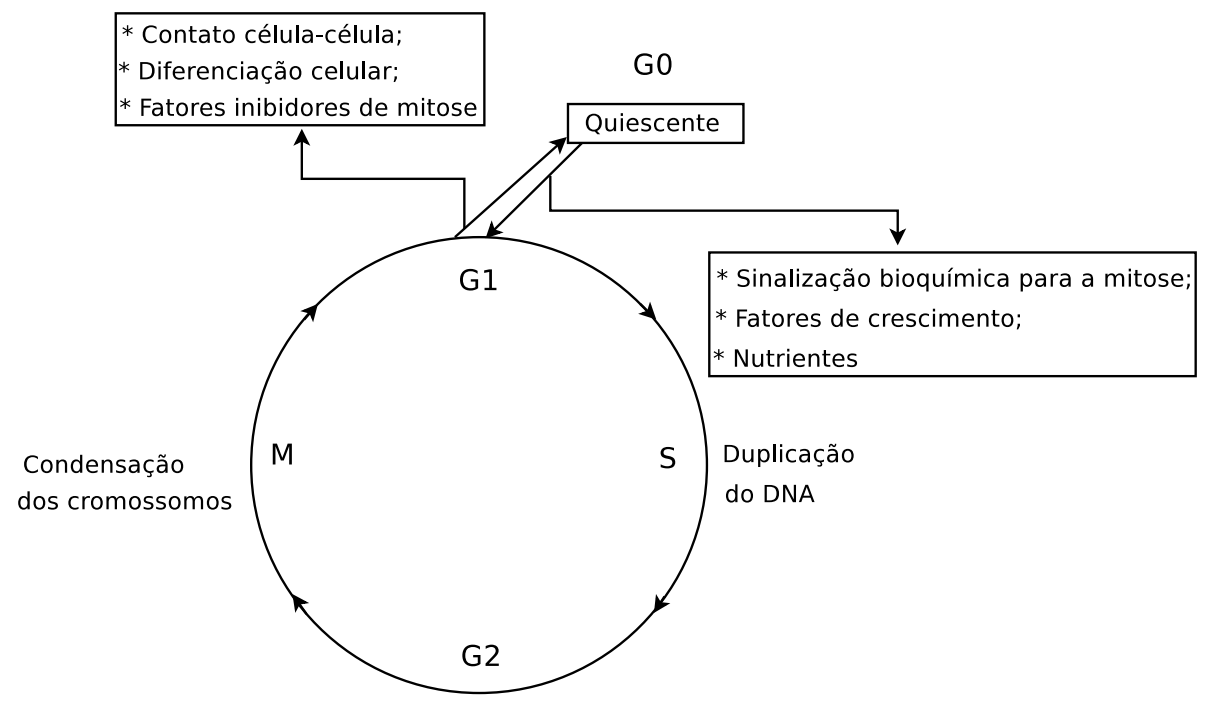

Figura 2.1: Figura adaptada da referência [8] que mostra esquematicamente as fases do ciclo celular.

A anormalidade no processo de divisão celular ou a falta de controle desse processo é que leva à formação de tumores: a célula com ciclo celular desregulado e que se reproduz autonomamente em relação ao meio que a circunda é dita tumoral ou tumorizada.

A transformação de uma célula normal em uma célula tumoral ocorre devido as alterações genéticas em trechos do DNA que desregulam o seu ciclo celular e sua comunicação com o meio externo. Essa comunicação é imprescindível para avisar a célula sobre quando é necessário entrar novamente no ciclo reprodutivo ou quando, even- 
tualmente, é necessária a sua morte, conhecida como apoptose. Esse mecanismo de morte celular, ou suicídio celular, existe para manter um número ótimo de células em um dado tecido ou para eliminar as células defeituosas com má formação genética.

No DNA das células existem alguns genes - chamados oncogenes - cuja expressão é responsável pela permanência da célula no ciclo celular e outros - conhecidos como supressores de tumor - cuja expressão é responsável pela saída do ciclo. Sabe-se que a combinação de uma expressão excessiva dos oncogenes, a diminuição da expressão dos supressores, juntamente com fatores que inibem a apoptose resulta na formação da neoplasia. Não há, no entanto, ainda uma certeza sobre o que, em um primeiro momento, causa a expressão anômala desses genes.

O acúmulo dessas alterações genéticas nas células e o consequente descontrole da reprodução celular leva a formação de, inicialmente, hiperplasias (nome dado aos tecidos do organismo onde uma célula é alterada de tal forma que suas filhas reproduzem-se demasiadamente), displasias (tecidos em que, além da divisão celular ser excessiva, as células possuem forma anormal), cânceres in situ ou pré-invasivo (tecidos com células mais anormais ainda em forma e função, mas que ainda não invadiram outros tecidos) e, finalmente, tumores malignos, que são capazes de invadir tecidos vizinhos e despejar células nos vasos sanguíneos. Uma vez na corrente sanguínea, essas células são capazes de originar novos tumores em outras regiões do organismo, fase conhecida como metástase [8, 9].

A figura 2.2 ilustra essa progressão tumoral, com a passagem de células normais alteradas geneticamente a células tumorais malignas.

Quando o tumor adquire a capacidade de invadir os tecidos que o 


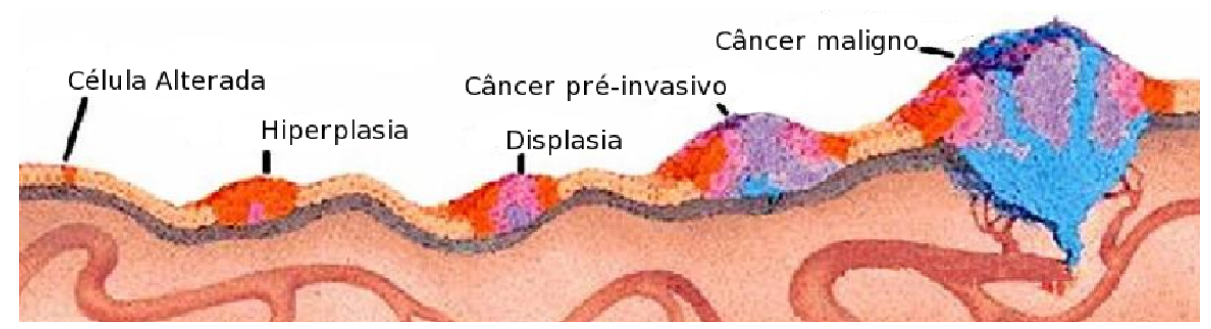

Figura 2.2: Figura extraída da referência [2]; mostra as diferentes fases de anomalia pelas quais passam as células até se transformarem em um tumor maligno: hiperplasia, displasia, câncer in situ, tumor maligno.

circundam, reproduzindo-se rápida e descontroladamente, ele é dito ser do tipo maligno. Em virtude do tipo de crescimento, o tumor maligno apresenta uma forma muito irregular em sua superfície e as suas células são completamente diferentes das do tecido que lhe deu origem.

A nutrição das células é feita através da difusão de nutrientes do meio intracelular, provenientes do sistema vascular. Há uma intensa competição por nutrientes entre as células de uma neoplasia maligna e as dos tecidos sadios vizinhos, e à medida que a massa tumoral cresce, essa competição aumenta e a disponibilidade limitada de nutrientes pode comprometer, em determinado momento, a continuidade do processo de crescimento dos tumores malignos.

A capacidade do tumor maligno induzir a formação de novos vasos sanguíneos é que constitui a sua faceta mais letal. Essa capacidade é conhecida como angiogênese. Uma vez criada uma rede de vasos que alimentará o tumor, a probabilidade de ocorrer metastáse aumenta enormemente, pois as células do câncer são fracamente ligadas e, consequentemente possuem alta mobilidade [8]. Enquanto (ou se) não há a formação de novos vasos sanguíneos, o tumor é chamado de avascular e parte dele necrosa.

A formação de colônias de células tumorais em órgãos distantes 
do foco inicial da nepolasia compromete a sobrevivência do organismo, dado que a proliferação excessiva das células neoplásicas e a constante competição por nutrientes com células sadias leva a um declínio das funções vitais. A figura 2.3 ilustra o processo de metástase.

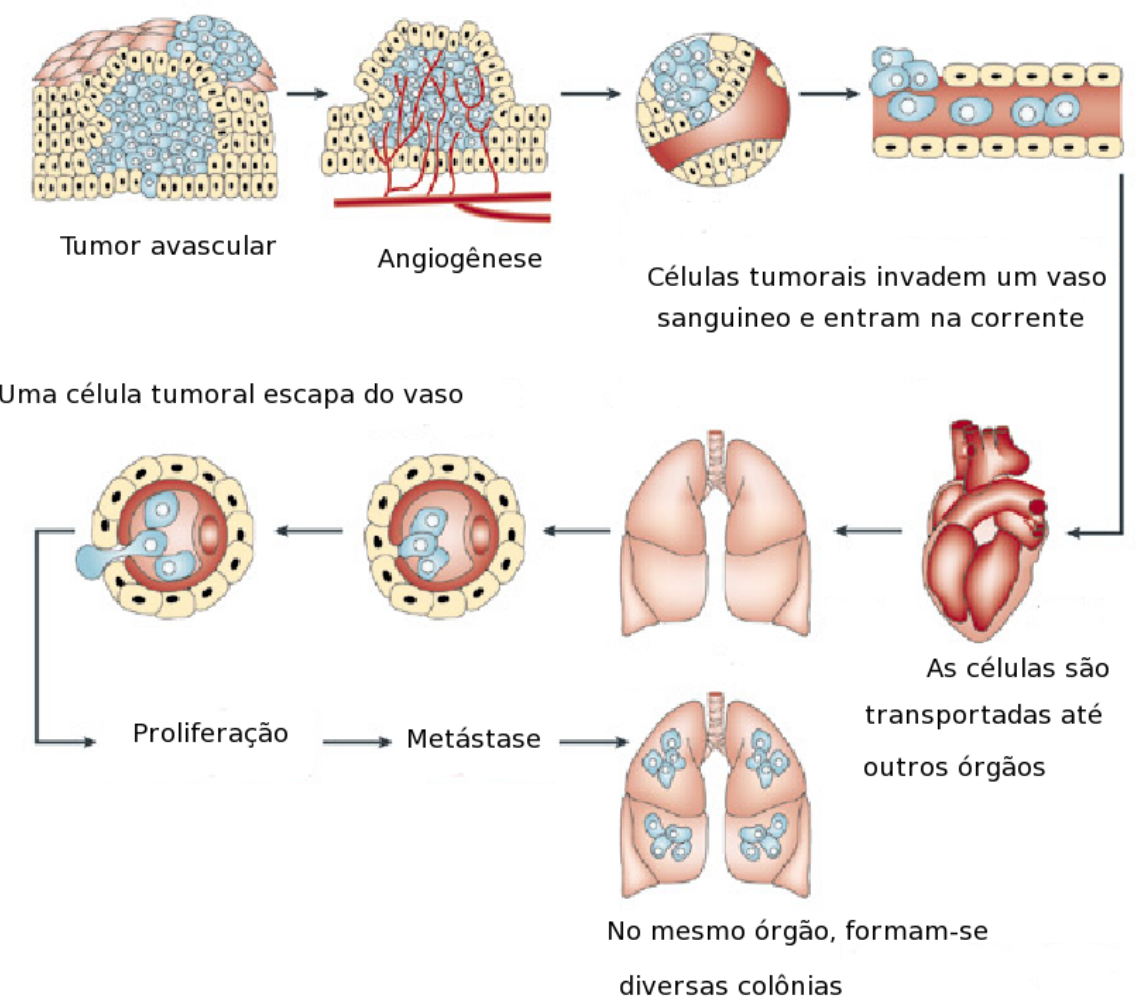

Figura 2.3: Figura adaptada da referência [9] que ilustra o mecanismo de formação de metástases.

Um exemplo de câncer muito recorrente é o de pele. A ocorrência desse tipo de tumor em paises tropicais como o Brasil é muito alta [10] devido a intensa exposição da população ao sol. Os raios ultravioletas são geralmente os causadores das mutações genéticas que ocorrem nas células constituntes da pele.

Como a pele é um órgão heterogêneo, a depender do tipo de 
célula que origina a neoplasia, ela recebe uma nomenclatura diferente: carcinoma basocelular, carcinoma epidermóide e melanoma. Desses, os tipos carcinomas são os menos agressivos e chamados genericamente de cânceres não melanoma pela comunidade médica. O melanoma é o tipo mais agressivo, capaz de provocar metástase rapidamente. Ele é o resultado da mutação dos melanócitos, células responsáveis pela produção de melanina, ${ }^{2}$ que se situam na região basal da epiderme. A figura 2.4 mostra um corte transversal da pele e as camadas que a formam (epiderme, derme e hipoderme), assim como os tipos de câncer de pele descritos.

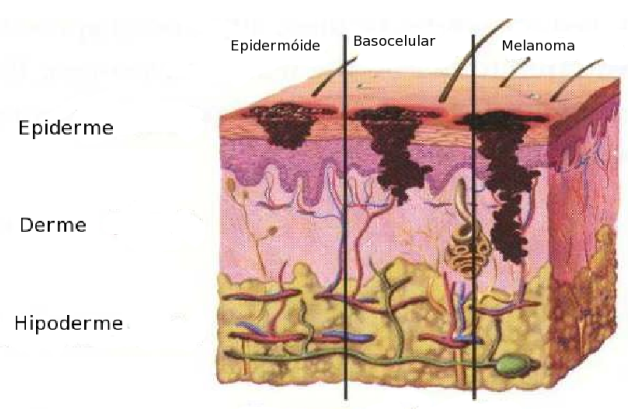

Figura 2.4: Figura adaptada de [11] que ilustra as camadas da pele e os tipos de câncer de pele.

Visto o perigo de metástase, é necessário um diagnóstico precoce do melanoma. Para esse fim foi estabelecido por especialistas um conjunto de propriedades conhecido como regra $A B C D$. Essas propriedades referem-se a diferentres aspectos das lesões da pele que indicam uma neoplasia maligna. $A$ diz respeito a assimetria; $B$ ao contorno irregular da borda; $C$ à coloração não uniforme e $D$ ao diâmetro. A figura 2.5 mostra como essas propriedades diferem em lesões benignas e malignas.

Com base nessas características, softwares comerciais (como por

\footnotetext{
${ }^{2}$ Melanina é a substância responsável pela pigmentação da pele que protege contra os raios ultravioletas.
} 
exemplo, [12] e [13]) foram criados para analisar imagens digitalizadas de lesões da pele, auxiliando na prevenção e diagnóstico de melanomas. Ao digitalizar a imagem de uma lesão do paciente, o médico é capaz de perceber, com o auxílio desses softwares, todas as alterações pelas quais um sinal de pele passa durante toda a vida do paciente e, com isso, diagnosticar precocemente o melanoma. Esses softwares calculam as propriedades geométricas de uma dada lesão e permitem uma comparação com medidas feitas anteriomente, muitas vezes imperceptíveis ao olho humano.

Softwares como esses, que ajudam no diagnótico e prevenção do câncer de pele, mostram ainda a importância da modelagem de tumores. Através de simulações, pode-se explorar novas características morfológicas que podem ser interpretadas como possíveis assinaturas de certas propriedades de crescimento ou agressividade de um tumor. É nessa perspectiva que se insere o presente trabalho.

A teoria descrita nesse item, sobre o desenvolvimento tumoral, é a que é classicamente aceita pela comunidade científica. Nessa teoria, qualquer célula tumoral que esteja presente no organismo é capaz de reiniciar e manter uma neoplasia maligna. Apenas recentemente surgiu na literatura uma hipótese inovadora, que pode mudar completamente a visão que se tem sobre a origem e o desenvolvimento do câncer, com consequências diretas nas formas de tratamento. Essa hipótese surgiu com o desenvolvimento do conhecimento das chamadas células tronco e com o aparecimento de evidências experimentais de sua provável tumorização. No próximo item, será mostrado, de forma bastante breve, como esse novo conhecimento pode mudar o entendimento da neoplasia. 


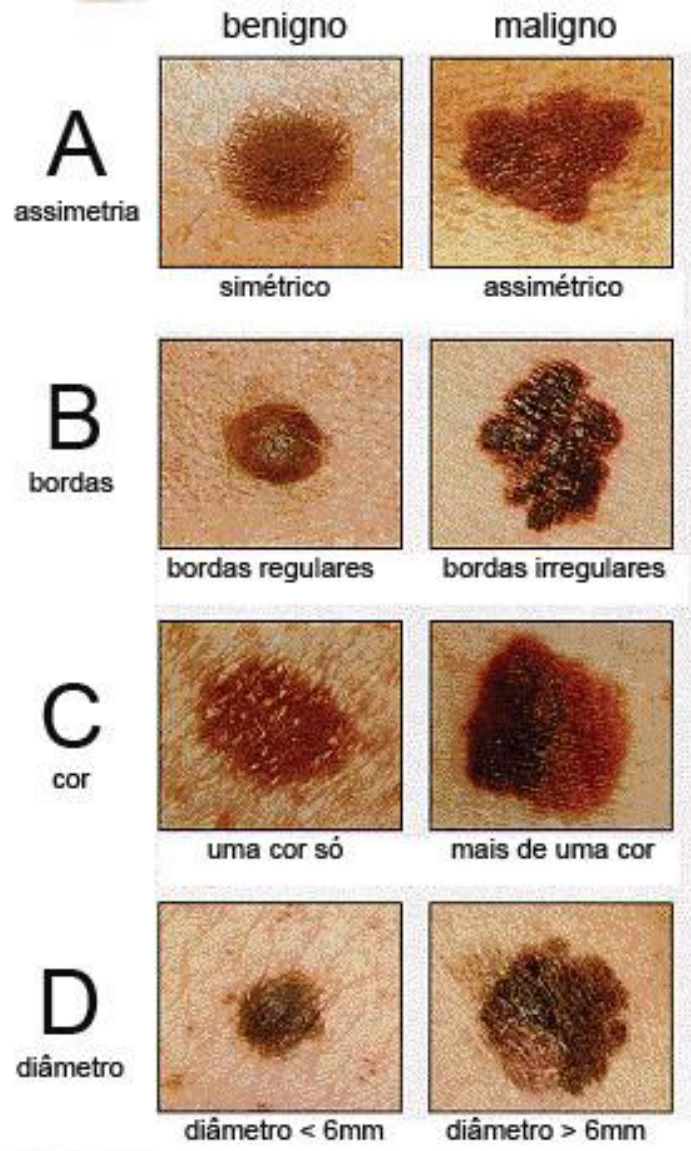

Figura 2.5: Regra $A B C D$. Figura adaptada de [11]. 


\subsubsection{Uma nova hipótese sobre a origem dos tumores}

Os primeiros estudos sobre a origem dos tumores datam de meados do século XIX. A hipótese de que as células tumorais tinham origem nas células normais do corpo $[14,15]$ foi durante muito tempo a hipótese mais aceita pelos pesquisadores, apesar do surgimento de outras. Só mais tarde, entretanto, com os estudos recentes sobre as chamadas células tronco, foi possível vislumbrar o papel dessas células na renovação celular, assim como a possibilidade de sua tumorização, uma vez que são células mais propícias a alterações genéticas do que as células altamente diferenciadas que fazem parte de tecidos e órgãos $[16,17]$.

Foi o pesquisador Rudolf Virchow quem postulou que os tumores tinham origem nas células adultas do corpo [14, 15]. Em 1867, o patologista Julius Cohnheim, contrariando a hipótese de Virchow, propôs que os tumores não são derivados de tecidos adultos, mas de resquícios de células embrionárias existentes no organismo adulto (hoje, essas células são conhecidas como células tronco). A hipótese de Cohnheim baseava-se nas observações microscópicas dos tecidos tumorais adultos que se assemelhavam aos tecidos embrionários [14, 15]. Apesar dessas semelhanças, essa nova teoria foi abandonada na época em virtude dos inúmeros experimentos com carcinomas que apontavam para a hipótese das células adultas serem as responsáveis pelo surgimento dos tumores.

Com os estudos sobre as bases genéticas do câncer e os fatores que causam as mutações necessárias para a tumorização das células, a hipótese inicial de Virchow tornou-se, com algumas considerações adicionais, um paradigma na pesquisa sobre o câncer. O pesquisador Wilhelm Waldeyer postulou ainda que qualquer célula em um dado 
órgão pode dar origem a um tumor [15]. Como cerca de $10^{11}$ novas células são originadas por dia no corpo humano, a probabilidade de incidência de tumores no organismo deveria ser alta, porém é rara. A explicação para isso apareceu com o desenvolvimento de uma teoria que considera que múltiplos eventos independentes devem ocorrer na célula, diversas mutações em genes, como por exemplo os oncogenes e os supressores de tumor, para que ela se tumorize. Quanto mais velha essa célula maior a probabilidade dela sofrer mutações nos seus genes.

A grande incidência de cânceres em crianças e em jovens adultos, assim como o surgimento de evidências de que as células diferenciadas dos tecidos não teriam tempo suficiente para sofrer mutações e tumorizar-se, apontaram contradições na teoria sobre o câncer mais aceita pelos cientistas.

A hipótese de que células menos diferenciadas (multipotentes) seriam as células que originam o câncer surgiu com experiências usando carcinomas de ratos $[15,16]$. Observou-se nessas experiências que as células tumorais eram capazes, quando transplantadas em outro organismo, de gerar tecidos normais (não malignos). Pesquisadores concluiram, com essa evidência, que somente um pequeno número de células presentes nos tumores são responsáveis pela manutenção do tumor.

A similaridade entre células tumorais e tronco foi primeiro verificada no contexto da leucemia. Em 1967, pesquisadores da Universidade de Washington demonstraram experimentalmente em pacientes com leucemia que tanto as células tumorais quanto as células diferenciadas tinham sido originadas de uma mesma célula mãe [16]. Décadas mais tarde, pesquisadores da Universidade de Toronto, utilizando uma nova técnica que permitiu cultivar células tronco hu- 
manas normais em camundongos, mostraram que somente uma subpopulação de células de um tipo de leucemia humana poderiam recriar a doença em camundongos quando transplantadas. O mesmo foi feito com outro tipos de cânceres: mama e pele. Novamente, os mesmos resultados foram obtidos [17].

\section{Similaridade entre células tronco e tumorais}

Células tronco são definidas como células não especializadas que têm a propriedade de perpetuar-se nos tecidos e órgãos de um organismo através da auto renovação, ou divisão celular, e gerar células maduras de um determinado tipo, através da diferenciação. Isso significa que todo tecido de um organismo origina-se de uma célula tronco específica. Muitas células tronco foram isoladas em diversos tipos de tecidos que comprovam essa hipótese. Exemplo disso são: células do fígado, medula óssea, polpa dentária, vasos sanguíneos, pâncreas, epitélio da pele e do sitema digestivo, córnea, retina e do cérebro [17, 18, 19]. A figura 2.6 mostra as duas propriedades características das células tronco: auto renovação e diferenciação.

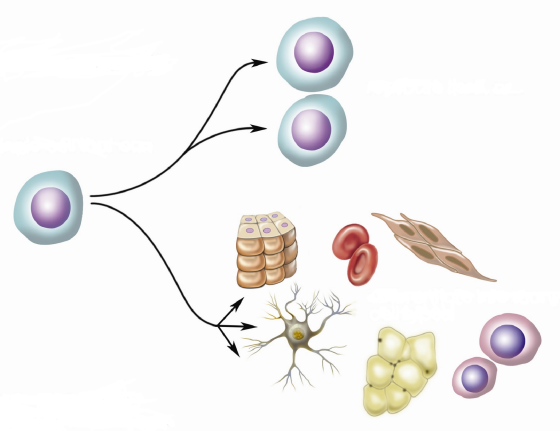

Figura 2.6: Auto renovação e diferenciação de uma célula tronco. Figura adaptada de [20].

A depender da sua origem e do seu poder de diferenciação em 
outras células do organismo, as células tronco são classificadas em: totipotente, pluripotente (conhecidas também como células tronco embrionárias) e multipotente (células tronco adultas).

A célula tronco totipotente é a única capaz de gerar um indivíduo, assim como os anexos embrionários placenta e membranas. Ela é o próprio ovo fecundado pelo gameta masculino, conhecido como zigoto. Somente o zigoto tem condições de gerar todos os tecidos e órgãos do corpo.

As células pluripotentes são derivadas do embrião nos primeiros dias de vida (fase conhecida como Blastócito ${ }^{3}$ ). Elas são capazes ainda de gerar qualquer tecido do corpo, porém não são capazes de gerar o indivíduo. O potencial de gerar diversos tipos de tecidos do corpo vai diminuindo com o desenvolvimento do embrião até ele formar-se completamente. Quando cultivadas em laboratório, essas células podem ser induzidas a diferenciar-se em um tipo celular desejado. A figura 2.7 mostra a evolução do organismo humano começando de uma célula tronco totipotente.

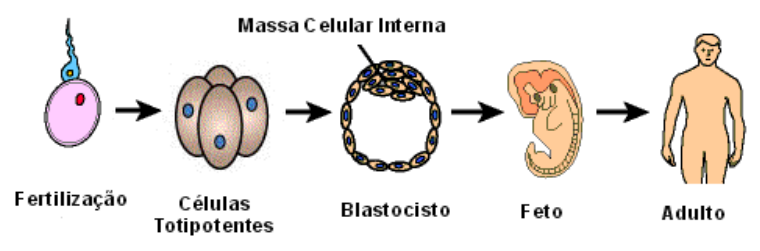

Figura 2.7: Evolução do organismo humano ao longo da vida. No início, uma célula totipotente, em seguida, encontrada na massa interna do Blastócito, as células pluripotentes. No organismo formado, as células tronco presentes são as adultas responsáveis pela renovação celular. Figura adaptada de [21].

As células tronco adultas são encontradas no indivíduo durante toda a sua vida e são responsáveis pela renovação celular em diver-

\footnotetext{
${ }^{3}$ Blastócito é um estágio do desenvolvimento do embrião. Ele é formado após a segmentação do zigoto
} 
sos tecidos e órgãos (manutenção e recuperação). Elas possuem um potencial de diferenciação bem mais reduzido que os outros tipos de células tronco e são encontradas em pequena quantidade no organismo [19].

Na maior parte do tempo de vida do organismo, essas células encontram-se no estado quiescente G0. Células da pele, sangue, fígado e intestino são renovadas constantemente no organismo e são as células tronco específicas em cada tecido as responsáveis pela produção dessas novas células. Um exemplo muito estudado de célula tronco é a hematopoiética.

A célula tronco hematopoiética é responsável pela produção das células que circulam no sangue (por exemplo, as hemácias e plaquetas) e algumas células que fazem parte do sistema imunológico (linfócitos). Uma pequena população dessas células está presente na mélula óssea e cada vez que novas células são necessárias para reposição no sangue ou na linfa ${ }^{4}$ a célula tronco hematopoiética produz uma progenitora com um grau de diferenciação intermediário. A figura 2.8 ilustra esse processo de diferenciação da célula hematopoiética.

As células progenitoras se dividem dando origem a outras células com maior grau de diferenciação até células completamente diferenciadas com baixo poder proliferativo e altamente especializadas. Dessa forma, a renovação celular é um complexo evento biológico desencadeado pela célula tronco que recebe sinalizações do meio externo quando há necessidade de reposição ou reparo.

O que mais surpreende nesse assunto é o fato de alguns mecanismos químicos associados à neoplasia também estarem relacionados à regulação do mecanismo de auto renovação das células tronco. Ex-

\footnotetext{
${ }^{4}$ Linfa é um líquido constituído pelo plasma sanguíneo, proteínas e por linfócitos. Ela é transportada pelos vasos linfáticos e filtrada nos linfonodos. Após a filtragem, é lançada no sangue.
} 


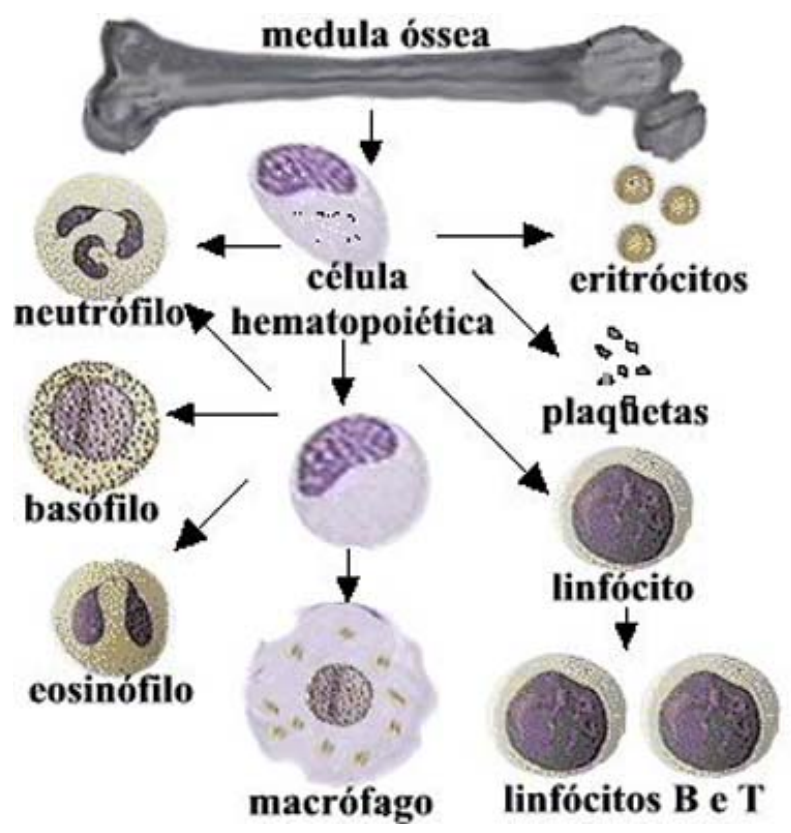

Figura 2.8: Na medula osséa, encontram-se as células tronco hematopoiéticas responsáveis pela produção dos nove tipos celulares e as hemácias presente no sangue. Nessa figura, alguns desses tipos celulares são ilustrados. Os mesmos princípios são aplicados a todas as células tronco adultas em outras regiões do corpo. Figura extraída de [22]. 
perimentos sugerem que substâncias que regulam a auto renovação das células tronco quando desreguladas, podem levar a formação de um tumor $[15,16,17,18,23]$.

De acordo com essa nova hipótese, a câncer seria originado a partir de uma dada célula tronco que se tumorizou devido à alterações genéticas e passou a se proliferar desreguladamente em relação ao meio extracelular. Ela daria origem a várias células com diferentes potenciais proliferativos.

O que candidata a célula tronco como a possível célula geradora de tumores é o fato de que ela possui naturalmente ativada a maquinaria química necessária para o processo de auto renovação no tecido ao qual ela pertence e, mantê-la em funcionamento, é mais fácil que ativá-la em outra célula mais diferenciada do tecido [17].

O mecanismo de auto renovação permite que essa célula mantenhase no organismo por toda a vida deste. Dessa forma, a probabilidade de ocorrer mutações genéticas nessas células é muito maior que em qualquer outra célula diferenciada do tecido que tem um tempo de vida muito menor. Haveria, então, tempo suficiente para a célula tronco acumular mutações e tumorizar-se [17].

Na figura 2.9, é ilustrada a diferença entre uma célula tronco normal e uma tumoral.

Para que uma célula diferenciada de um tecido tumorize, é necessário que ela adquira a capacidade de auto renovar-se, para depois sofrer mutações que ocasionem possíveis alterações genéticas. Como a probabilidade desse evento ocorrer é considerada baixa, essas células diferenciadas são fracas candidatas a assumir o papel de células iniciadoras de tumor.

Todo esse conhecimento é algo novo na literatura médica e marca uma profunda mudança de paradigma no entendimento da neopla- 


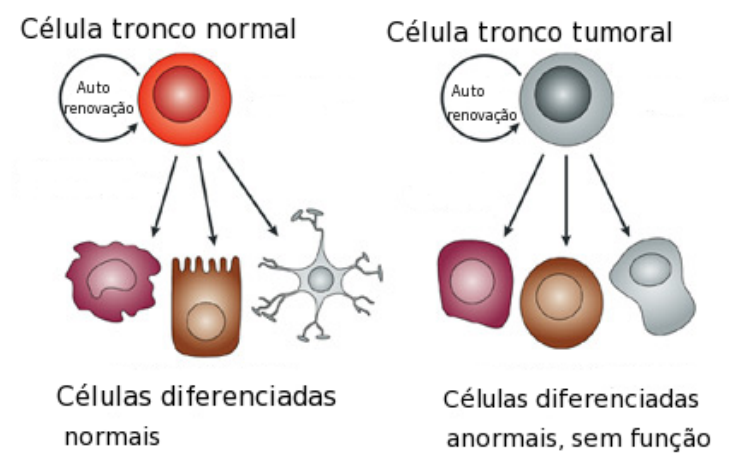

Figura 2.9: Figura adaptada da referência [18] que mostra a diferença entre células tronco normal e tumoral. A célula tronco normal origina células especializadas saudáveis, necessárias à sobrevivência do organismo. A célula tronco tumoral gera descontroladamente células diferenciadas, porém não especializadas e sem função. Essas formam a massa tumoral e comprometem a vida do organismo.

sia, pois considera a possibilidade de serem outras as células iniciadoras de tumor, as chamadas células tronco tumorais. Experimentos demonstram ainda que essas células são resistentes a tratamentos convencionais como quimioterapia e isso pode ser a explicação da reincidência de tantos casos de câncer que aparentemete haviam regredido em pacientes $[15,16,17,18,23,24,25,26]$.

Todas as estratégias de tratamento e cura, eram até então pensadas para combater outras células, o que mostra a urgente necessidade de mais estudos que considerem a hipótese da tumorização da célula tronco. A figura 2.10 mostra as estratégias para o tratamento do câncer.

É com essa nova justificativa biológica para o surgimento do câncer em vista que se propôs nesse projeto de mestrado um modelo computacional simplificado que leva em conta os aspectos essencias de auto renovação, diferenciação celular e mobilidade de células com características atribuídas às células tronco num tumor avascular. $\mathrm{O}$ desenvolvimento do modelo é detalhado no capítulo 3. 


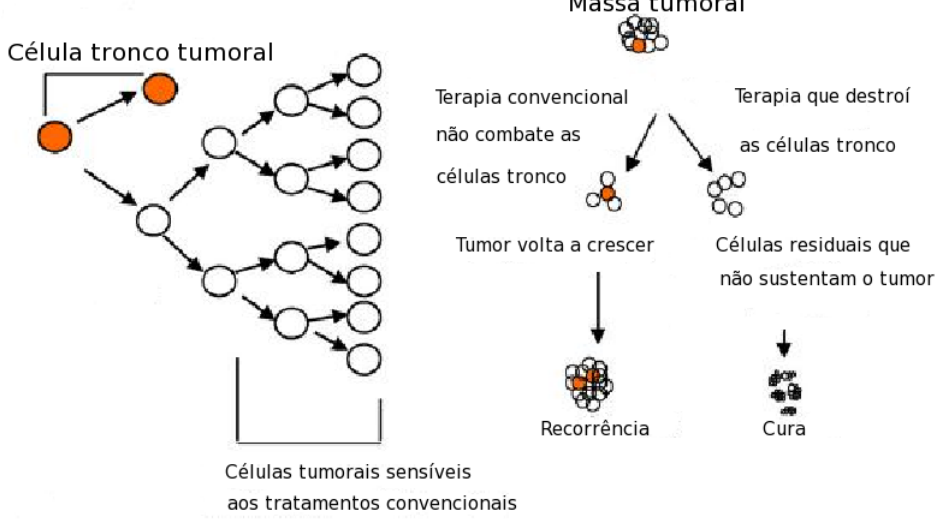

Figura 2.10: Figura adaptada da referência [15] que ilustra as terapias de combate ao câncer. A primeira é a convencionalmente adotada que elimina todas as células tumorais. Nesse caso, como as células tumorais são sensíveis aos tratamentos, elas são mortas. Entretanto, as verdadeiras células que mantém o tumor, as tronco tumorais, permanecem vivas e reestabelecem o tumor. Uma terapia adequada, segundo a nova teoria, deveria combater as células que iniciam e mantem o tumor: as tronco tumorais.

\subsubsection{Modelagem matemática de tumores}

Todo o conhecimento descrito anteriormente sobre a biologia do câncer mostra que a evolução tumoral pode ser analisada em três escalas principais: microscópica, mesoscópica e macroscópica. A escala microscópica refere-se aos fenômenos que acontecem a nível molecular, como mutações genéticas ou mudanças na expressão de alguns genes; a escala mesoscópica trata o problema a nível celular, considerando aspectos como a interação célula-célula e célula-matriz extracelular; a abordagem macroscópica refere-se aos fenômenos que ocorrem nos tecidos, como difusão de nutrientes e fatores químicos, interação com outros tecidos e a formação de metástase $[2,3,4]$.

Existe uma infinidade de modelos matemáticos que tentam descrever o desenvolvimento de tumores e que diferem da escala a que se propõem a modelar às ferramentas matemáticas e computacionais 
utilizadas.

Uma boa parte dos modelos encontrados na literatura com o objetivo de simular o crescimento tumoral é baseada na chamada abordagem cinética. Nesta abordagem - comum na química e bem sucedida em inúmeros outros problemas, como no estudo da propagação de epidemias, - definem-se variáveis médias que caracterizam o tumor como um todo (densidade de células tumorais ou densidade de nutrientes, por exemplo) e sua evolução no tempo é descrita por equações diferenciais acopladas. Estas, por sua vez, são tratadas com técnicas analíticas típicas do estudo de sistemas dinâmicos, ou por integração numérica. Uma outra abordagem que vem ganhando espaço e importância é a abordagem chamada estocástica. Nesta abordagem os modelos são autômatos celulares ou mapas acoplados, as células são representadas por elementos unitários em uma rede e a interação entre elas é definida através de regras locais. A evolução no tempo se dá por algorítmos do tipo Monte Carlo, daí a origem do nome. O modelo proposto nesse trabalho enquadra-se nessa última categoria.

Nas referências $[5,6,7,27,28,29,30,31,32]$, podem-se encontrar alguns exemplos das diferentes abordagens matemáticas que vem sendo empregadas no estudo desse problema e em [2, 3] tem-se algumas revisões sobre o assunto. Não se pretende aqui fazer uma revisão bibliográfica completa do assunto. Apresentar-se-ão apenas resumos e comentários de alguns trabalhos mais relacionados com os resultados a serem apresentados nessa dissertação, como [32] e [33]. Todos eles concentram-se na análise da escala mesoscópica.

Em [33], Ferreira Jr. e colaboradores propõe um modelo misto para simular um carcinoma in situ, que contempla as seguintes ações: proliferação, motilidade e morte celular. Há dois tipos de 
células: normais e tumorais. O tecido saudável (normal) é representado por uma rede quadrada com condições de contorno fixas. A interação célula-célula permite que as células apresentem probabilidades locais distintas para cada uma das ações consideradas. Essa interação é mediada por fatores de crescimento e a concentração destes obedecem uma equação de difusão sobre a rede.

A principal característica obtida com esse modelo é a existência de uma transição morfológica no período transiente. Dependendo da motilidade celular, o crescimento inicial muda de um padrão compacto e menos invasivo (nos casos de baixa motilidade celular) para padrões esparsos e mais invasivos (nos casos de alta motilidade celular). Entretanto, os padrões finais de crescimento obtidos nas simulações são compactos, mesmo nos casos com alta motilidade. Em [34], diferentes regras para a reprodução foram propostas usando-se o mesmo modelo estudado em [33]. Os resultados mostraram que o comportamento de certas grandezas, como o número de células tumorais, são independentes das regras locais de reprodução. Em todos os casos, o número de células tumorais, em função do tempo, ajusta-se à uma curva gompertziana [4]. Essa curva frequentemente descreve o crescimento tumoral observado experimentalmente.

Em [32], Brú e colaboradores utilizam técnicas de escala para analizar a natureza fractal de alguns tipos de colônias de células tumorais crescidas in vitro. O estudo sistemático da geometria fractal desses tumores e a teoria de escala permitiu concluir que, em todos os casos, o crescimento pertencia à classe de universalidade $M B E$ (Molecular Beam Epitaxy), incompatível com a idéia corrente na literatura de crescimento gompertziano [6, 34]. Essa dinâmica de crescimento $(M B E)$ é caracterizada por três mecanismos: (a) taxa de crescimento linear ; (b) atividade de crescimento que se restringe 
à superfície do tumor; (c) a existência de difusão de células na superfície. Essas características geralmente não são consideradas nas teorias correntes entre os médicos e biológos. Assim, de acordo com [32], o principal mecanismo responsável pelo crescimento seria a difusão das células ao longo do tumor. A figura 2.11, extraída da referência [32], ilustra uma sequência de imagens (de a a f) de uma colônia de células tumorais. Em (a) é vista uma célula logo após a divisão e o resto das imagens mostram o movimento dessa célula ao longo da borda tumoral.

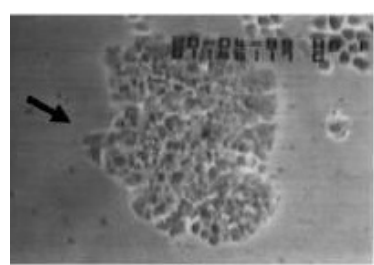

a)

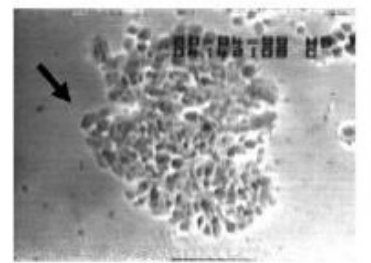

c)

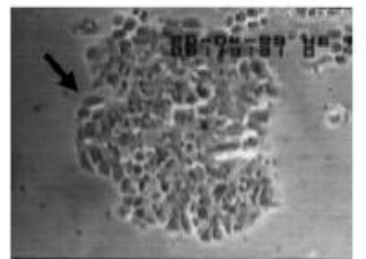

e)

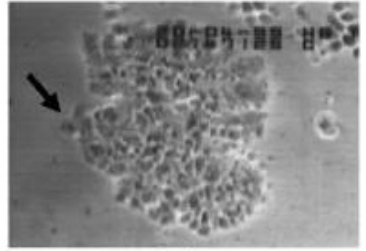

b)

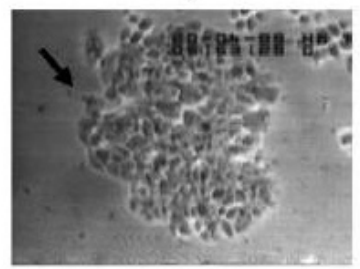

d)

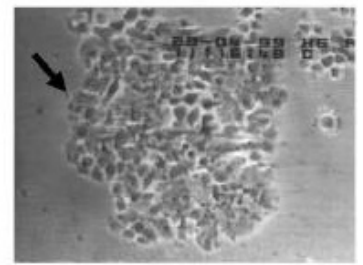

f)

Figura 2.11: Figura extraída da referência [32] que ilustra a motilidade de uma célula tumoral. 


\section{Capítulo 3}

\section{Descrição do modelo numérico}

\subsection{Introdução}

Tendo em vista a importância da descoberta de células com características atribuídas às células tronco em diversos tipos de tumores $[9,15,16,17,18]$, bem como de indícios de que sua motilidade pode ter um papel relevante no desenvolvimento dos mesmos, investigouse nesse trabalho, através de simulações computacionais, o papel tanto da motilidade quanto da diferenciação na dinâmica de crescimento de um tumor avascular. Dir-se-á que os "tumores" gerados por simulações numéricas são tumores crescidos in silico.

Como não se encontrou na literatura nenhum modelo computacional que contemplasse a presença desse tipo de célula, desenvolveuse um modelo completamente original de crescimento tumoral, que possibilita diferentes taxas de reprodução para cada tipo de célula, considera a eventual mobilidade de um desses tipos bem como a possibilidade de diferenciação . 
O modelo é um autômato celular probabilístico bidimensional com atualização assíncrona, definido em um reticulado. Cada elemento da rede pode estar vazio ou conter uma célula tumoral. Existem duas espécies de células tumorais: as rotuladas tipo 2 tem capacidade de auto renovação, diferenciação e mobilidade, e representam as células com características de células tronco; as rotuladas tipo 1 são células diferenciadas, somente com capacidade de reprodução , que também surgem a partir da reprodução de uma célula do tipo 2 .

A taxa de reprodução de cada célula é definida por uma função chamada de limiar de reprodução $(L R)$, em princípio diferente para células tipo 1 e tipo 2. Supõe-se também que o tumor é avascular e crescido em um tecido "mole", ou seja, o processo de degradação da matriz extracelular e do tecido sadio em seu entorno é rápido e fácil, e portanto não é considerado. Como há abundância de alimentos, a velocidade de crescimento é definida apenas pelo limiar de reprodução ${ }^{1}$.

A função Limiar de reprodução (LR) de uma célula tumoral é função do número de células tumorais presentes na sua vizinhança, ou seja, da topologia do tumor no seu entorno. Com a mudança desta função, o modelo pode reproduzir uma situação em que (a) esta dependência não existe; (b) o crescimento é governado basicamente pela competição por espaço; (c) é governado pela eventual maior concentração de nutrientes presentes nas "dobras" existentes na superfície de crescimento [32] ou (d) é governado por uma competição entre ambos os efeitos.

Considerando-se os mecanismos de auto renovação e de difer-

\footnotetext{
${ }^{1}$ Estas duas últimas hipóteses são adequadas para a descrição de tumores crescidos in vitro, como os que vêm sendo estudados na UNIFESP e com os quais pretende-se, no futuro, comparar os resultados obtidos.
} 
enciação celular característicos das células tronco, impôs-se que as células do tipo 2, ao reproduzirem-se, podem gerar células do mesmo tipo (2) ou células do tipo 1 . Embora, na realidade, haja muito mais que um tipo de célula completamente diferenciada em um tumor real - o que o deixa com uma grande variabilidade fenotípica celular [8] - considerou-se no modelo somente um tipo de célula diferenciada (tipo 1), por simplicidade.

Como há evidências experimentais que células em processo de reprodução não se movem, o modelo considera primeiro a mobilidade celular, para só depois decidir a respeito da reprodução , conforme será melhor explicado a seguir.

\subsection{Estrutura do programa}

O autômato celular proposto neste trabalho evolui em uma rede quadrada bidimensional regular $L \times L$, onde cada sítio pode assumir, no instante $t$, um entre três valores inteiros: 0,1 ou 2 . O valor 0 representa sítios vazios, ou seja, o meio externo ao tumor, que, como já foi dito, é considerado facilmente degradável, não opondo resistência ao seu desenvolvimento. Os valores 1 (2) indicam, respectivamente, sítios que contém células tumorais do tipo 1 (tipo 2). Os sítios que contém células tumorais (1 ou 2) serão genericamente chamados de sítios ativos.

A vizinhança de um determinado sítio é definida como o conjunto dos 8 sítios adjacentes a ele (vizinhança de Moore). A figura 3.1 ilustra esta vizinhança.

Há total flexibilidade na definição do tecido tumoral inicial: número de células (uma ou mais), tipo de célula (só tipo 1 , só 2 ou ambos), geometria (que pode ter qualquer formato, mais arredondado 
ou mais alongado, por exemplo), ou simetria (posicionamento aleatório ou localização assimétrica pré-definida das células tipo 1 e 2). Apesar dessa flexibilidade, decidiu-se utilizar, no presente estudo, em todas as simulações, um tecido tumoral inicial composto somente por duas células, uma do tipo 1 e outra do tipo 2 , situadas no centro da rede.

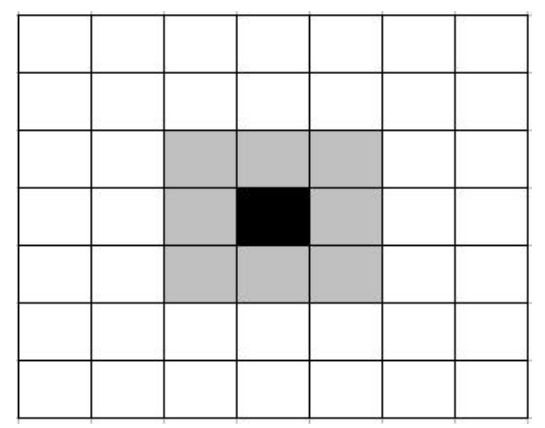

Figura 3.1: Vizinhança de Moore. Sítio ativo em preto e a sua vizinhança em cinza.

A partir do tumor inicial a simulação evolui com um algoritmo de Monte Carlo: um sítio da rede é escolhido aleatoriamente; se o sítio sorteado for uma célula tumoral (um sítio ativo), verifica-se qual o seu tipo. Caso seja do tipo 2, ele eventualmente se locomove com uma certa probabilidade definida por um parâmetro chamado PROBANDA; caso não se mova, eventualmente se reproduz com uma probabilidade definida pela função $L R$ adequada ao seu tipo de célula. Se a célula sorteada for do tipo 1 (sem mobilidade) ela poderá se reproduzir com probabilidade $(1-P R O B A N D A) \times L R$, conforme será melhor explicado no item 3.2.2.

Um tempo de monte carlo (TMC) é definido como $L^{2}$ sorteios de sítios, em que $L$ é o tamanho da rede. Dessa forma, em média, cada sítio é atualizado uma vez em um TMC. A simulação se encerra quando o tumor toca uma das bordas do reticulado. Para exempli- 
ficar, a figura 3.2 ilustra um exemplo numérico de um tumor crescido em uma rede $10 \times 10$ obedecendo a condição de parada. O padrão de cores usado será mantido ao longo de todo o texto: sítios vazios são coloridos com azul, celulas tumorais do tipo 1 aparecem em branco e do tipo 2 em vermelho.

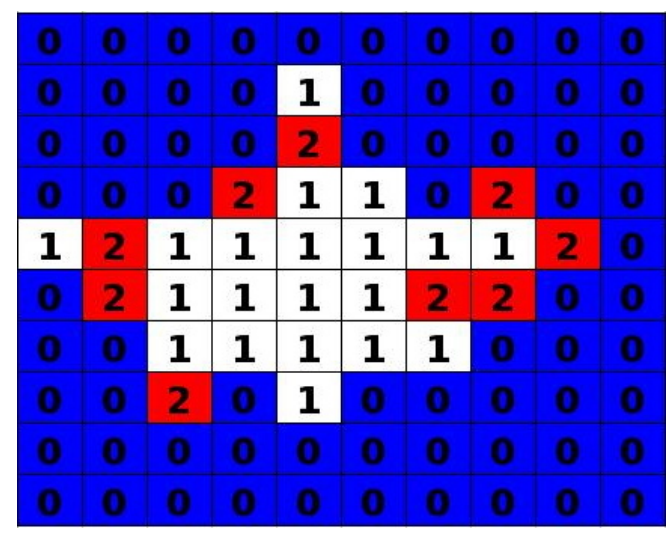

Figura 3.2: Exemplo de um tumor crescido in silico a partir de duas células iniciais localizadas no centro do reticulado. A figura mostra a configuração final obtida quando o tumor toca a borda. Sítios vazios em azul, celulas do tipo 1 em branco e do tipo 2 em vermelho. $\mathrm{L}=10 ; \mathrm{LR}_{1}$ e $\mathrm{LR}_{2}=0,5 ;$ PROBANDA $=0,5 ;$ PROBDIF $=0,5$.

\subsubsection{Motilidade das células tipo 2 (difusão)}

Células do tipo 2 podem eventualmente mover-se um sítio ao longo do tumor. Chamou-se, nessa dissertação, esse movimento genericamente de difusão, embora nem sempre possa ser descrito como um processo difusivo clássico, equivalente a um caminho aleatório ou a um movimento browniano.

Seguindo-se evidências experimentais, considerou-se que uma célula em processo de reprodução não se move. A maior ou menor mobilidade de uma célula é definida por um parâmetro que foi denominado PROBANDA: cada vez que uma célula tipo 2 é sorteada, ela se moverá com uma probabilidade $P=P R O B A N D A$. Caso a 
célula se movimente, não poderá se reproduzir no mesmo sorteio.

Uma vez definido que a célula se move, resta a questão de definir para onde ela se movimentará. A alternativa mais simples seria considerar que ela se moveria com igual probabilidade (aleatoriamente) para qualquer uma das posições vazias de sua vizinhança. Entretanto, isso aparentemente não corresponde ao que é observado. Há evidências experimentais e teóricas (ver por exemplo [32]) de que o movimento ocorre, na maioria das vezes, sobre a superfície do tumor e que fatores topológicos locais podem direcionar esse movimento para alguns sítios em detrimento de outros.

Nas regiões côncavas, a concentração de nutrientes e sinalizadores de crescimento tende a ser maior, uma vez que todas as células excretam enzimas que degradam a matriz extra celular ${ }^{2}$. A figura 3.3 , retirada da referência [32], elucida esse mecanismo.

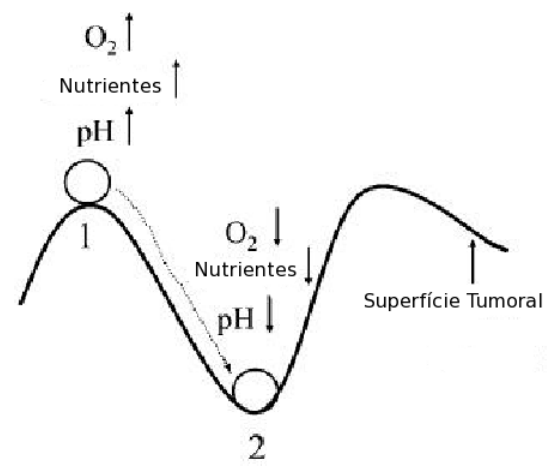

Figura 3.3: A figura mostra a direção na qual uma célula teria maior probabilidade de se movimentar. A figura foi extraída da referência [32].

\footnotetext{
${ }^{2}$ Assumiu-se a hipótese de que há nutrientes em abundância no meio em que o tumor está crescendo, portanto esse não é um limitante. Essa hipótese é bastante realista para o crescimento de tumores in vitro, com os quais se pretende, num primeiro momento, comparar os resultados dessa simulação .
} 


\section{Restringindo o movimento à superfície}

Como realizar uma análise completa da topologia local do tumor, com um algoritmo numérico, é um problema de grande complexidade, necessitando de algoritmos não locais (ver figura 3.4), adotouse um algoritmo aproximado que garante as hipóteses acima.

O algoritmo desenvolvido visou evitar que o tumor se dividisse ou que as células se "descolassem" durante a difusão, além de favorecer o movimento em situações como a apresentada na figura 3.3.
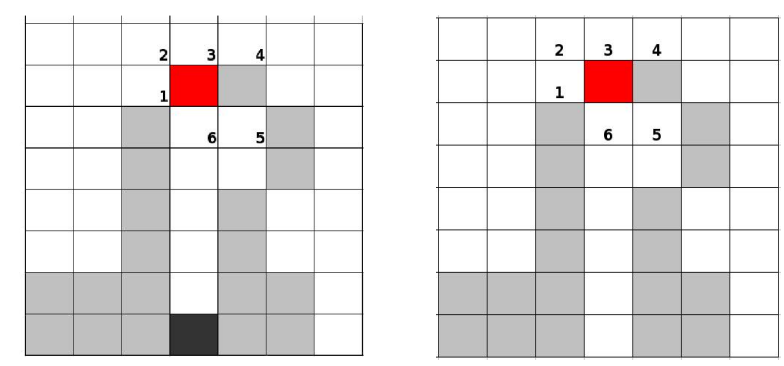

Figura 3.4: Exemplo da complexidade do problema numérico a ser tratado. No caso (a), a célula vermelha pode se difundir para o sítio vazio 3 sem que o tumor se parta em dois pedaços; já no caso (b) esse movimento deveria ser proibido. A única diferença entre as duas configurações está na célula cinza escuro, que encontra-se distante da célula prestes a se mover (vermelha), deixando clara a complexidade e não localidade do problema.

Impôs-se no modelo que a difusão sempre ocorre ao longo da superfície tumoral, o que significa que sítios vazios sem vizinhos ativos ou com no mínimo um vizinho ativo não são sítios candidatos à difusão da célula tipo 2 . A figura 3.5 mostra alguns exemplos de sítios para onde não pode ocorrer a difusão de uma célula tipo 2 (vermelha). Os sítio vazios vizinhos à célula estão numerados. A superfície tumoral está colorida em cinza.

Outra imposição do modelo foi limitar a difusão da célula tipo 2 em função do número de células ativas presentes na sua vizinhanhça. Caso ela só tenha 1 vizinho ativo ou nenhum, ela é impe- 

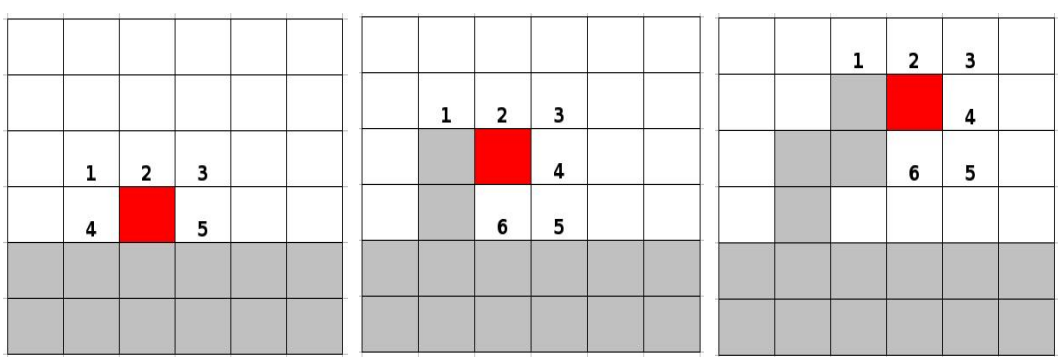

Figura 3.5: No primeiro exemplo, o sítio vermelho não pode mover-se para os sítios 1, 2 e 3, de acordo com as regras do modelo. Ele tende a mover-se com igual probabilidade para o sítio 4 ou 5 . Da mesma forma, no segundo exemplo, o sítio vermelho não pode deslocar-se para os sítios 3 e 4 . Ele pode mover-se para 1, 2, mas com menor probabilidade que para os sítios 5 e 6 . No terceiro exemplo, os sítios proibidos são os 3, 4 e 5; O sítio mais provável para o deslocamento é o 6 .

dida de mover-se, pois determinados perfis em que isso acontece não são tão favoráveis ao deslocamento. A figura 3.6 ilustra algumas configurações onde a célula tipo 2 é impedida de deslocar-se.
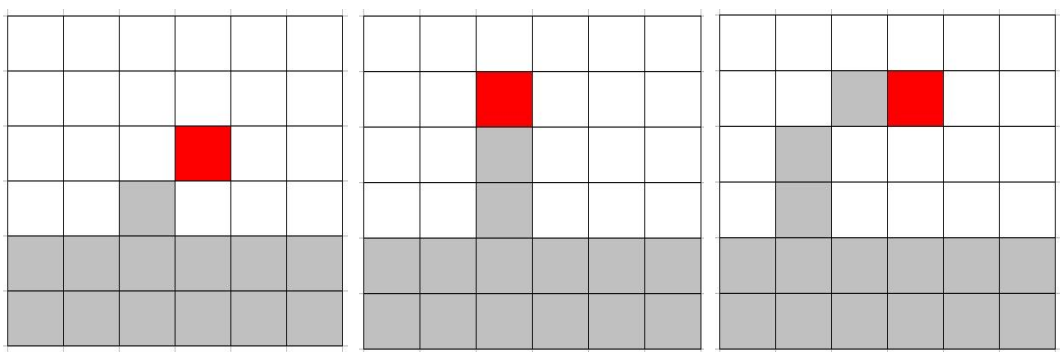

Figura 3.6: Exemplos de configurações em que uma célula tipo 2 é impedida de mover-se.

\section{Levando em conta a topologia local}

O tipo de locomoção apresentado na figura 3.3 indica um mecanismo de difusão anômala, no qual as células que se movem o fazem sob a ação de um potencial local, que aumenta a probabilidade de que se desloquem para os sítios vazios vizinhos a elas que, por sua vez, tenham os maiores números de células ativas (tipo 1 ou tipo 2 ) vizinhas a eles. Foi assumido que a probabilidade de uma célula 
tipo 2 se movimentar para certo sítio vazio de sua vizinhança será tão maior quanto maior o número de sítios ativos que este sítio vazio tiver.

Associou-se, portanto, uma maior probabilidade de locomoção para os sítios da vizinhança que, estando vazios, tivessem um maior número de células ativas. Essa probabilidade é diretamente proporcional ao número de células ativas vizinhas ao vizinho vazio, com algumas correções introduzidas de forma ad hoc, inspiradas em uma análise cuidadosa e detalhada de algumas configurações observadas nas simulações .

Para os casos em que o vizinho vazio tem 5 vizinhos ativos, considerou-se, devido à analise de várias configurações, um peso maior que quando este tinha 6 vizinhos ativos, o que parece contradizer a hipótese inicial. Entretanto, a visualização de algumas superfícies tumorais sugeriu que vizinhos vazios com 5 vizinhos ativos fossem locais de difusão mais prováveis que os que tinham 6 vizinhos ativos, por representarem melhor as situações descritas em 3.3.
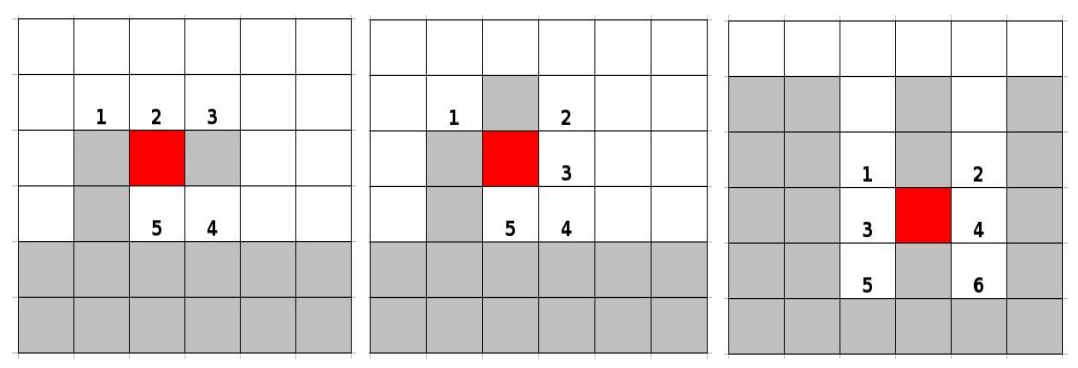

Figura 3.7: No primeiro exemplo, a célula tem igual probabilidade de mover-se para os sítios 1 e 3 . Essa probabilidade é menor que a probabilidade de deslocarse para o sítio 2 . O sítio com maior peso é o 5 . No segundo exemplo, o sítio 5 também é o local mais provável para a locomoção da célula vermelha. No terceiro exemplo, os sítios 1, 2, 3 e 4 possuem mesmo peso, menor que o dos sítios 5 e 6 , que seriam os locais para os quais a célula tipo 2 vermelha tenderia a se movimentar.

Com base no exposto, foi concebido o perfil de probabilidade de 
difusão para um dado sítio vazio vizinho a um sítio tipo 2 apto à difundir-se. Nas figuras 3.5 e 3.7 vê-se alguns dos casos considerados para a construção do perfil apresentado na figura 3.8.

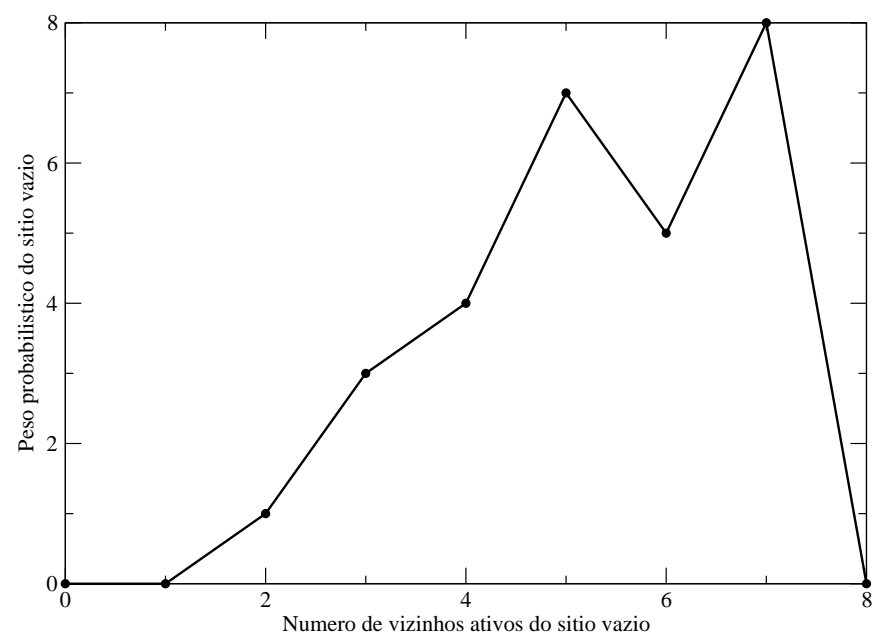

Figura 3.8: Pesos que definem as probabilidades de locomoção para os diversos vizinhos vazios de uma célula tipo 2 que se move.

Baseado nesse perfil, pode-se calcular a probabilidade de um sítio tipo 2 mover-se para um dos sítios vazios de sua vizinhança. Dado um certo vizinho vazio $i$, e seu respectivo peso $P_{i}$, assim como os pesos de todos os vizinhos vazios $P_{j}$ do sítio tipo 2 em questão, fornecidos pelo perfil da figura 3.8, a probabilidade $P_{i}^{\prime}$ do sítio moverse para o vizinho $i$ é fornecida pela equação 3.1,

$$
P_{i}^{\prime}=\frac{P_{i}}{\sum P_{j}}
$$

Na figura 3.9, a célula tipo 2 (vermelha) tem 4 sítios vizinhos vazios, que foram numerados de 1 a 4 . Esses vizinhos vazios tem, respectivamente, 3, 1, 3 e 6 vizinhos ativos. A probabilidade de que ela se mova para o sítio vazio $4(1,2,3)$ é igual a $5 / 11(3 / 11,0$, 
$3 / 11)$.

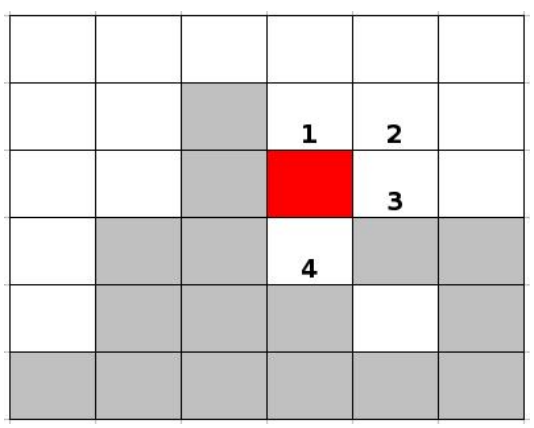

Figura 3.9: Exemplo de um célula tipo 2 e seus vizinhos vazios. O sítio para o qual a célula tipo 2 teria maior probabilidade de se mover seria a de número 4 .

\section{Implementação da subrotina de difusão}

A subrotina DIFUSÃO descrita no item anterior foi implementada de acordo com o seguinte procedimento:

1. Um sítio da rede é sorteado aleatoriamente;

2. Um número aleatório entre 0 e 1 é sorteado e comparado ao parâmetro PROBANDA. Caso esse parâmetro seja maior que o número sorteado, o sítio sorteado está apto a se mover;

3. Se o sítio sorteado for do tipo 2, a subrotina DIFUSÃO é chamada;

4. Verifica-se se o número de vizinhos ativos do dado sítio é maior que 1, condição para continuar na subrotina;

5. Calcula-se o número de vizinhos vazios que existem na sua vizinhança, e verifica-se se é diferente de zero, ou seja, se há espaço vazio na vizinhança para a locomoção da célula;

6. Para cada sítio vazio, calcula-se o número de vizinhos ativos e monta-se uma lista. Cada elemento da lista tem o endereço 
do vizinho vazio do sítio sorteado. O número de elementos da lista, com um mesmo endereço, é igual ao peso atribuído ao dado sítio vazio. Por exemplo, se um sítio vazio tem 5 vizinhos ativos, então, segundo a figura 3.8, o seu peso deve ser 7. Portanto, 7 elementos da lista terão seu endereço;

7. Sorteia-se um dos elementos da lista;

8. O sítio vazio cujo endereço foi sorteado e o sítio sorteado inicialmente têm seus estados trocados;

9. Verifica-se se o tumor tocou a borda da rede, i.e, se o sítio para onde a célula tipo 2 se moveu é um sítio de borda;

10. Se o o tumor tocou na borda do reticulado, o programa é interrompido. Caso contrário, a simulação continua e outro sítio da rede é sorteado.

A figura 3.10 mostra o diagrama de Nassi-Shneiderman da subrotina descrita acima, supondo que o sítio sorteado seja do tipo 2 em condições de difundir-se (itens 1 a 5 omitidos no diagrama):

\begin{tabular}{|c|}
\hline \multicolumn{2}{|c|}{ Dado de entrada da subrotina: sítio sorteado } \\
\hline \multicolumn{2}{|c|}{ Para cada vizinho vazio, execute } \\
\hline \multicolumn{2}{|c|}{ Calcula o número de vizinhos ativos } \\
\hline Verifica o peso desse sítio \\
\hline Atribui o endereço desse sítio a diferentes elementos da lista \\
\hline \multicolumn{2}{|c|}{ Sorteia um elemento da lista } \\
\hline Atualiza o estado do sítio sorteado igual a 0 \\
\hline Atualiza o estado do sítio vazio sorteado igual a 2 \\
\hline Sim Esse sítio é de borda? \\
\hline Simulação para e gera \\
arquivo de saída
\end{tabular}

Figura 3.10: Diagrama de Nassi-Shneiderman da subrotina de difusão. 


\subsubsection{Reprodução das células}

Os dois tipos de células tumorais do modelo tem capacidade de se reproduzirem. Células tipo 2 , com características de célula tronco, podem, nesse processo, dar origem a células iguais a ela ou diferentes, em um processo conhecido como diferenciação. Denominarse-á, todos esses processos pelo nome único de reprodução.

Para que uma célula ativa se reproduza, ao menos um sítio de sua vizinhança deve estar vazio. Nesse caso (ou seja, se houver espaço), ela irá se reproduzir com uma probabilidade $P^{\prime \prime}$, e uma nova célula tumoral ocupará, com igual probabilidade, qualquer um dos sítios vazios de sua vizinhança.

Como foi visto, a cada sorteio verifica-se se o sítio sorteado é preenchido por uma célula ativa e, em caso positivo, se a célula é tipo 2 e se move. Caso a célula sorteada seja do tipo 2 e não tenha se movimentado, ou caso ela seja uma célula tipo 1, ela se reproduzirá com uma probabilidade $P^{\prime \prime}$ definida pelo limiar de reprodução LR, que é função da topologia local do tumor.

Uma célula tipo 2 pode originar dois tipos de célula (1 ou 2) durante a reprodução. Para controlar esse processo, inseriu-se um novo parâmetro no modelo, chamado PROBDIF. Este parâmetro é a probabilidade de uma célula tipo 2 dar origem a uma célula tipo 1. Em todas as simulações, esse parâmetro foi fixado em 0,5.

A função Limiar de Reprodução LR é uma função discreta que define a probabilidade de reprodução de uma célula ativa em função do número de células ativas vizinhas a ela. Seu domínio é o conjunto $\{1,2,3,4,5,6,7\}$, visto que o número de vizinhos vazios é necessariamente menor que 8 e uma célula sem vizinhos vazios não tem espaço para se reproduzir. 
Células tipo 2 podem ter uma função LR diferente da de células tipo 1 . Por simplicidade, assumiu-se que esta dependência é linear, podendo ser crescente, decrescente ou constante (nesse caso, LR é insensível à topologia local).

Caso o crescimento seja governado por uma competição por espaço, é razoável supor que LR seja uma função decrescente do número de vizinhos ativos; caso a competição seja por nutrientes, LR é crescente com o número de vizinhos ativos; finalmente, a situação LR constante representa o caso onde a probabilidade de reprodução não depende da topologia local. O caso LR constante foi utilizado para caracterizar um modelo nulo em relação ao qual foi possível avaliar os efeitos das diversas formas funcionais de LR, que é um dos objetivos dessa dissertação.

Como já foi dito, considerou-se a função LR como linear, ou seja, o Limiar de Reprodução cresce (decresce) linearmente com o número de vizinhos ativos (NVIZ) da célula que irá se reproduzir. A reta que define a função é definida por dois parâmetros, MIN e MAX, em que MIN $=\operatorname{LR}(1)$ e MAX $=\operatorname{LR}(7)^{3}$, e dada pela expressão:

$$
L R=\left[\frac{M A X-M I N}{6}\right] N V I Z+\left[\frac{7(M I N)-M A X}{6}\right]
$$

A figura 3.11 exemplifica o uso desta função: a célula sorteada (que pode ser tanto do tipo 1 ou do tipo 2 ) aparece em verde e os demais sítios ativos aparecem em cinza; há três posições vazias e cinco sítios ativos em sua vizinhança. Considerando-se MIN = 0,1 e $\operatorname{MAX}=0,9$ (caso crescente), $\mathrm{MIN}=0,9$ e $\mathrm{MAX}=0,1$

\footnotetext{
${ }^{3}$ Para células tipo 1, tem-se os parâmetros MIN1 e MAX1, e para células tipo 2 tem-se MIN2 e MAX2. Se MIN < (>) MAX a função é crescente (decrescente); se MIN = MAX o limiar de reprodução é constante e não depende da topologia local do tumor.
} 
(caso decrescente) e MIN $=$ MAX $=0,9$ (caso constante), obtém-se, respectivamente, $L_{\text {cresc }}=0.63, L_{\text {decres }}=0.37$ e $L R_{\text {constante }}=0,9$.

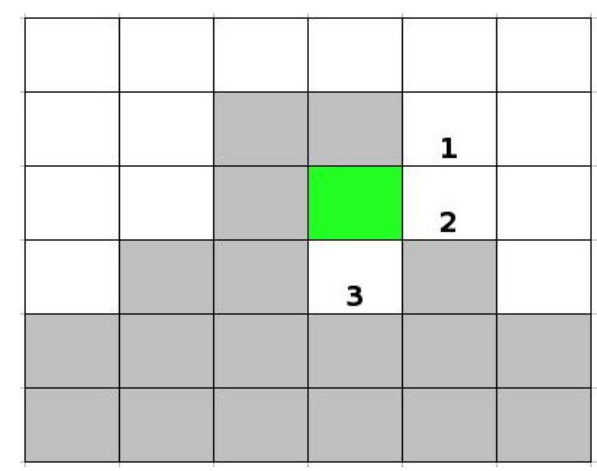

Figura 3.11: Exemplo do uso da função LR. Supondo a função crescente, com MIN $=0,1$ e MAX $=0,9$, a célula verde se reproduz com probabilidade (LR) $=0,63$; se a função for decrescente, com $\mathrm{MIN}=0,9$ e MAX $=0,1$, então a probabilidade de se reproduzir (LR) muda para 0,37 . Se LR for constante a probabilidade de reprodução é 0,9 .

Caso a célula se reproduza, uma nova célula tumoral será acrescentada em um dos sítios vazios de sua vizinhança com igual probabilidade. Se a célula que se reproduz for tipo 2, ela irá se diferenciar com uma probabilidade definida pelo parâmetro PROBDIF; caso se diferencie, faz-se necessário decidir onde ficará a nova célula (tipo 1) gerada: no sítio vizinho a ser ocupado ou na posição original da célula que se duplicou ${ }^{4}$. A célula diferenciada (tipo 1) irá para a nova posição com probabilidade 0,5 .

A figura 3.12 ilustra algumas configurações dada a reprodução da célula (verde) da figura anterior supondo que ela seja do tipo 2 e se diferencie. A probabilidade de cada configuração é dada por $(1-$ probanda $) \times L R \times 1 / 3 \times 1 / 2$, visto que existe também a possibilidade de troca de posições entre a célula tipo 2 que se reproduziu e a nova célula do tipo 1 originada. Caso a célula verde da figura

\footnotetext{
${ }^{4}$ Quando uma célula duplica ela desaparece e duas novas células são geradas. Portanto, a célula diferente pode ocupar a posição inicial da célula que se duplicou ou a nova posição a ser ocupada por uma célula tumoral.
} 
3.11 fosse do tipo 1 ou mesmo do tipo 2 e não se diferenciasse, o número das configurações possíveis reduziria pela metade.
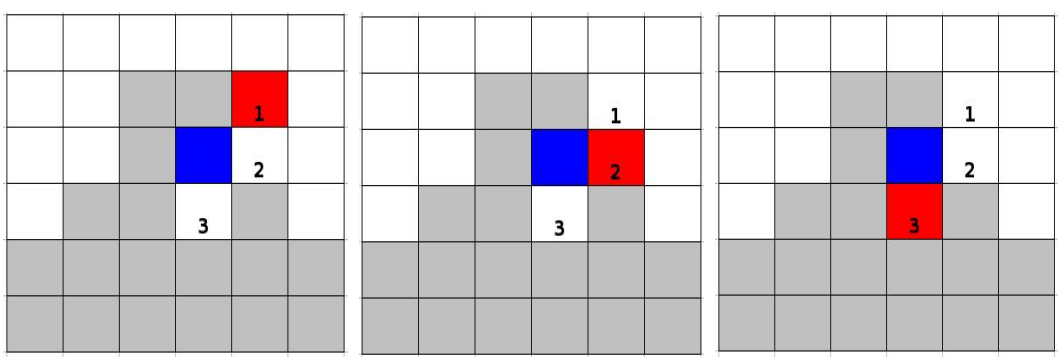

Figura 3.12: Possíveis configurações dada a reprodução da célula (verde) da figura 3.11, supondo que ela seja do tipo 2 e se diferencie. Cada sítio vazio (1, 2 e 3) tem a mesma probabilidade (1/3) de ser ocupado pela célula filha do tipo 1. A probabilidade de transição da configuração da figura 3.11 para cada uma dessas é de $(1-$ probanda $) \times L R \times 1 / 3 \times 1 / 2$. Em todas essas configurações as posições entre a célula tipo 2 e sua filha tipo 1 foram trocadas.

\section{Implementação da subrotina de reprodução}

A implementação dessa subrotina foi feita da seguinte forma:

1. Um sítio da rede é sorteado;

2. Se esse sítio não se move, a subrotina de reprodução é chamada;

3. Calcula-se o número de sítios vazios na sua vizinhança e verificase se este número é diferente de zero;

4. Cria-se uma lista com os endereços de cada sítio vazio da vizinhança;

5. Calcula-se o LR do sítio através da equação (3.2);

6. Um número aleatório entre 0 e 1 é sorteado e comparado com o valor de LR. Se LR é maior que o número sorteado, o sítio irá se reproduzir;

7. Sorteia-se um dos elementos da lista; 
8. Se o sítio sorteado for tipo 1, o sítio vazio, cujo endereço foi sorteado tem seu estado atualizado em 1;

9. Se o sítio sorteado for do tipo 2, sorteia-se outro número aleatório e compara-se ao parâmetro PROBDIF (suposto nessa dissertação sempre igual a 0.5$)$;

10. Se PROBDIF é maior que o número sorteado, o novo sítio será do tipo 1; caso contrário, do tipo 2;

11. Se o novo sítio for do tipo 1, outro número aleatório é sorteado e, caso esse número seja maior que 0,5 , o sítio vazio, que foi previamente sorteado, tem seu estado atualizado em 2. O sítio que se reproduziu tem seu estado atualizado em 1 ;

12. Caso o número aleatório anterior seja menor que 0,5 , o sítio tipo 2sorteado não muda de posição com a nova célula tipo 1 , de forma que somente o sítio vazio tem seu estado atualizado igual a 1 ;

13. Verifica-se se o tumor tocou a borda. Se não tocou a borda, outro sítio da rede é sorteado.

A figura 3.13 mostra o diagrama da subrotina descrita, supondo que o sítio sorteado esteja em condições de se reproduzir (itens 1 a 4 omitidos no diagrama).

\subsection{Diagrama do programa principal}

O diagrama do programa principal usado para simular a evolução tumoral é visto na figura 3.14. 


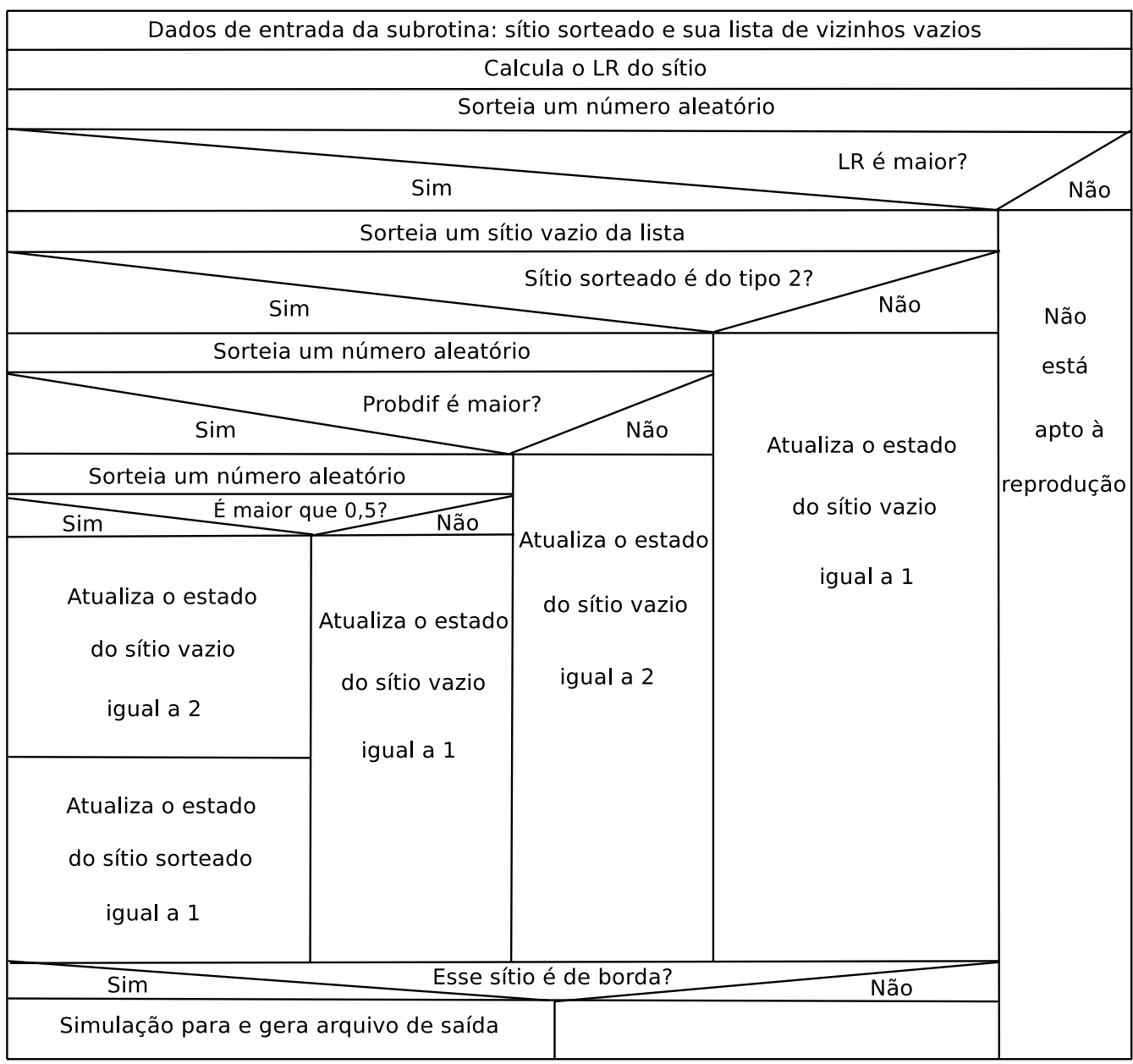

Figura 3.13: Diagrama de Nassi-Shneiderman da subrotina de reprodução . 


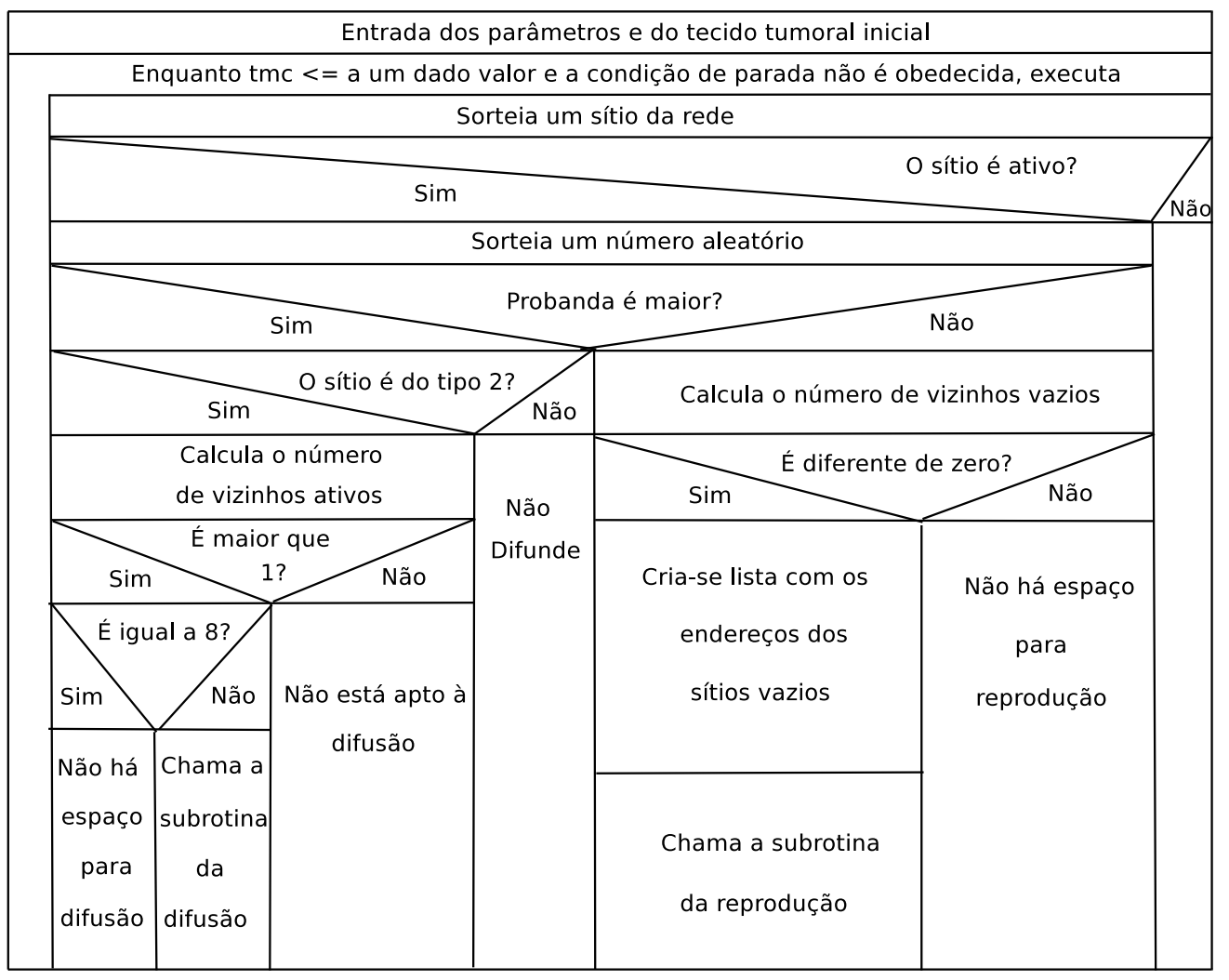

Figura 3.14: Diagrama de Nassi-Shneiderman do programa principal. 


\subsection{Considerações gerais}

A motivação principal desse trabalho foi tentar modelar o crescimento de células tumorais com características de células tronco e comparar com as observações experimentais obtidas por colaboradores da Escola Paulista de Medicina (Unifesp). Apesar dessa motivação inicial, a comparação quantitativa das simulações obtidas com o modelo com imagens obtidas a partir do crescimento de colônias de células em cultura não foi realizada e deverá ser feita no futuro.

O caminho para se chegar na versão apresentada foi longo. Realizaram-se muitas discussões com os colaboradores e várias versões preliminares (hipóteses) tiveram que ser testadas e descartadas, até que se chegasse a um conjunto de regras que se mostrasse satisfatório e compatível com o que se conhece experimentalmente. Como muitos aspectos experimentais ainda são controversos na literatura, optou-se por um modelo mais versátil, que explorasse as possíveis consequências, no crescimento do tumor, das hipóteses mencionadas no item 3.2 .

O programa desenvolvido para implementar o modelo foi feito em linguagem $\mathrm{C}$ e o gerador de números aleatórios usado na versão final do programa foi o ran2 com um período em torno de $2 \times 10^{18}$, disponibilizado em [35], uma vez que as simulações foram feitas em redes grandes (usou-se redes $2000 \times 2000$ para investigar o regime estacionário do modelo). Este gerador retorna um número uniformente distribuido no intervalo $(0,1)$ excluindo os extremos e é chamado no código a partir de um inteiro negativo, a semente do gerador aleatório.

As simulações foram realizadas no cluster Abax do Grupo de 
Mecânica Estatística do Departamento de Física Geral da Universidade de São Paulo. O cluster, que tem como sistema operacinal o Linux, possui um servidor e 14 nós com processadores Intel Q9300, 8 GB de memória RAM no servidor e $2 \mathrm{~GB}$ em cada nó [36].

Para cada conjunto de parâmetros estudado nesse trabalho foram realizadas 100 simulações a partir de sementes diferentes. Cada conjunto de 100 simulações foi colocado em um nó do cluster e, em média, demorou cerca de 4 dias para ser finalizado (redes $2000 \times$ 2 000), a depender do valor dos diversos parâmetros, pois estes influenciavam o tempo que o tumor levava para atingir a borda da rede.

Foi escrito um script em bash que inseria as entradas (parâmentros e semente) no executável do programa em C a cada nova simulação - Toda simulação tinha como saída um arquivo com informações sobre o número de células (tipos 1 e 2) em função do tempo e a matriz quando o tumor tocava a borda. Essa matriz numérica era convertida em imagem com a ajuda de outro script que a inseria no aplicativo xmgrace.

As imagens dos tumores foram muito úteis, uma vez que forneciam um retrato estático do processo dinâmico ocorrido, ou seja, padrões morfológicos obtidos através de diferentes taxas de reprodução, diferentes funções LR e diferentes mobilidades das células. Por limitações práticas, apenas considerou-se imagens de redes $250 \times 250$.

Outros scripts foram desenvolvidos para ajudar na análise dos resultados obtidos que calculavam as médias do número de células (ambos os tipos), os desvios quadráticos dessas médias e os tempos finais de cada simulação, nas 100 simulações realizadas para cada conjunto de parâmetros estudado.

Embora não tenha sido possível realizar uma comparação quan- 
titativa entre os resultados experimentais e numéricos, pode-se afirmar que, ao menos qualitativamente, o modelo desenvolvido prevê várias características observadas em tumores crescidos in vitro realizados pelos colaboradores do Laboratório de Biofísica da Escola Paulista de Medicina da Universidade Federal de São Paulo Unifesp, como será discutido no capítulo 4. 


\section{Capítulo 4}

\section{Resultados das simulações}

\subsubsection{Introdução}

Para investigar o potencial do modelo numérico proposto na seção anterior, realizou-se simulações em redes de $2000 \times 2000$ sítios, com a finalidade de caracterizar o regime quase estacionário do modelo. As simulações foram iniciadas sempre da mesma maneira, com duas células ativas situadas aproximadamente no centro da rede.

Para cada caso estudado foram geradas cem simulações que diferiam apenas na semente do gerador de números aleatórios. Um paralelo pode ser feito entre simulações computacionais e medidas feitas em laboratório: as simulações seriam como se medidas fossem realizadas, mantidas as mesmas condições experimentais. Nesse caso, mesmas condições experimentais significa dizer mesmos tipos de células, submetidas às mesmas condições ambiente (temperatura, umidade, pH, concentração de nutrientes etc). A aleatoriedade do processo de medida tem origem no fato de que nem todas as condições experimentais podem ser repetidas; ela é reproduzida nas simulações através do método de Monte Carlo.

Na primeira parte do trabalho foi investigado o comportamento 
apresentado pelo modelo para algumas funções LR (limiar de reprodução), definido conforme a equação 3.2. O objetivo foi perceber de que forma as regras microscópicas de crescimento e difusão afetavam a morfologia (forma macroscópica) do tumor e o seu ritmo de crescimento.

As análises consistiram em ver como o número de células dos dois tipos presentes na rede ( $N_{1}$ para células do tipo 1 e $N_{2}$ para as do tipo 2 ) evoluiam com o tempo (aqui tempo significa Tempo de Monte Carlo) ${ }^{1}$, assim como relacionar algumas das propriedades observadas nessas séries temporais com as imagens dos tumores obtidas em redes $250 \times 250$. A visualização das imagens auxiliou na compreensão qualitativa da dinâmica tumoral, uma vez que certas grandezas (como rugosidade, dimensão fractal da borda do tumor, número de células presentes na borda) não foram calculadas. Os cálculos dessas grandezas serão futuramente implementados no programa.

Para cada conjunto de cem simulações, verificava-se o tempo de Monte Carlo final de cada simulação (tempo que o tumor levava para tocar na borda da rede). O menor valor do tempo encontrado servia para truncar as demais séries temporais do conjunto; a média do número total de células de um dado tipo $i$, para cada tempo $\mathrm{t}$ $\left(N_{i}(t)\right)$ foi calculada utilizando-se todas as $j=100$ simulações

$$
\left\langle N_{i}(t)\right\rangle=N_{i}(t)=\frac{1}{100} \sum_{j=1}^{j=100} N_{i}^{j}(t) .
$$

Por simplicidade, os símbolos $\langle$,$\rangle serão omitidos, ficando suben-$ tendido que os resultados sempre se referem à média sobre 100 simulações.

\footnotetext{
${ }^{1} \mathrm{O}$ Tempo de Monte Carlo será abreviado simplesmente por $\mathbf{t}$ ao longo da dissertação.
} 


\section{Modelos estudados}

Com o objetivo de criar uma referência que permitisse a comparação e interpretação dos resultados desse trabalho, definiu-se dois modelos chamados nulos. Os resultados foram, então, comparados com o modelo completo apresentado na seção 4.0.3.

\section{Modelo Nulo 1}

O modelo denominado nulo 1 é definido pelos seguintes parâmetros: MIN1 = MAX1 = 0,5 (ou seja, uma função LR neutra); PROBDIF $=0$ (não há diferenciação de células) e PROBANDA $=0$ (não há difusão). Só há um tipo de célula (tipo 1 ou tipo 2 já que o comportamento de ambas passa a ser idêntico) e este tem apenas a capacidade de reprodução. Esse é o modelo de crescimento mais simples já visto na literatura [33, 37] e que é baseado apenas na deposição aleatória de novas células tumorais na borda do tumor.

\section{Modelo Nulo 2}

O modelo denominado nulo 2 é definido pelos mesmos parâmetros do modelo nulo 1, exceto pelo valor de PROBANDA e do tipo de célula inicial, que agora é necessariamente tipo 2 . Como PROBDIF $=0$, o tumor continua a ter somente um tipo de célula. Quando comparado com o modelo nulo 1, permite entender o papel da motilidade das células na dinâmica de crescimento tumoral. Foram considerados os valores 0,2, 0,5 e 0,8 para PROBANDA.

\section{Modelo Completo}

Além dos modelos nulos, estudou-se o modelo completo, com dois tipos de células e capacidade de diferenciação para células do tipo 2. Nesse caso, três tipos de funções LR foram consideradas: uma função neutra, ( $L R_{\text {constante, }}$ que coincide com o empregado nos modelos nulo 1 e nulo 2), um perfil crescente $\left(L R_{\text {cresc }}\right)$ e um decrescente 
$\left(L R_{\text {decres }}\right)$. Esses perfis refletem a interação das células tumorais com sua vizinhança. A função LR é definida pelos parâmetros MIN e MAX, e, embora o programa permita funções de reprodução diferentes para os dois tipos de célula, na caracterização do Modelo Completo, estudou-se apenas o caso onde ele era o mesmo, ou seja, em todos os casos estudados MIN1 = MIN2 = MIN e MAX1 = MAX2 $=$ MAX.

A função $L R_{\text {constante }}$ tem os parâmetros $\mathrm{MIN}=\mathrm{MAX}=0,5$. Quando esse perfil de reprodução é adotado, a taxa de reprodução não depende da vizinhança na qual a célula está inserida. Na função decrescente $\left(L R_{\text {decres }}\right), \mathrm{MIN}=0,9$ e MAX $=0,1$. Esse perfil reflete uma competição das células por espaço, uma vez que se reproduzem mais se tem menos células tumorais na sua vizinhança. Na função crescente $\left(L R_{\text {cres }}\right), \mathrm{MIN}=0,1$ e MAX $=0,9$. Nesse perfil, a reprodução de uma célula é favorecida quando o número de vizinhos ativos em sua vizinhança é maior. A figura 4.1 ilustra as três funções LR consideradas nesse trabalho.

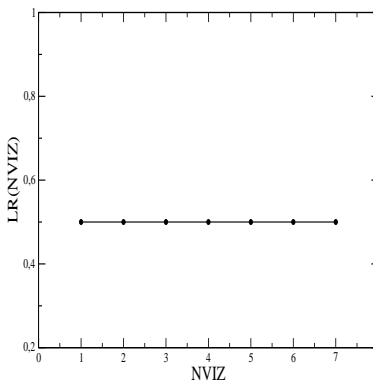

(a) Constante

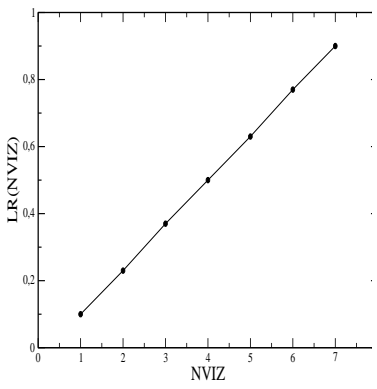

(b) Crescente

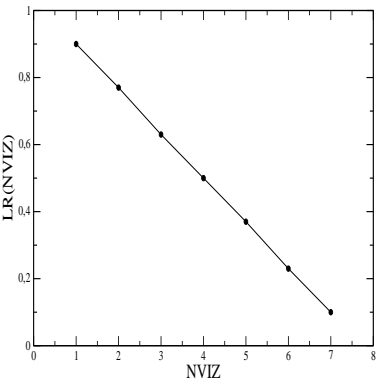

(c) Decrescente

Figura 4.1: Gráfico das três funções Limiar de Reprodução (LR) consideradas no trabalho: (a) $L R_{\text {constante }}$, para a qual $\mathrm{MIN}=\mathrm{MAX}=0,5$; (b) $L R_{\text {cresc }}$ para a qual MIN $=0,1$ e MAX $=0,9$ e (c) $L R_{\text {decres }}$ com $=0,9$ e MAX $=0,1$. 
Na segunda parte do trabalho foi investigada uma possível transição de fase descoberta no modelo, como consequência de uma maior ou menor motilidade das células. O modelo exibe uma fase dita metastática, na qual células do tipo 2 estão sempre presentes na borda do tumor e uma fase dita não metastática, em que as células do tipo 2 param de se reproduzir em um determinado momento, ficando aprisionadas no interior da massa tumoral.

Por fim, são exibidas algumas imagens de culturas de células tumorais obtidas pelos nossos colaboradores da UNIFESP. Elas servem para ilustrar como o modelo concebido, que considera a existência de células com características de célula tronco em tumores, está de acordo, qualitativamente, com o que se observa nos experimentos in vitro.

\subsubsection{Modelos Nulos}

\section{Modelo nulo 1}

A média das séries temporais obtidas com as simulações do modelo nulo 1 foi calculada de acordo com 4.1 e é apresentada na figura 4.2. Nessa figura, apresenta-se o logarítmo do número total médio de células $\left(N_{1}\right)$ como função do logarítmo do tempo $t$, junto com a sua derivada local ${ }^{2}$.

Observa-se dois regimes de crescimento. A derivada local dessa curva apresenta um máximo local, o que significa que na curva original há um ponto de inflexão. Passado um período transiente, observa-se um regime estacionário descrito por uma lei de potência,

$$
N_{1}(t) \sim(t)^{\eta} .
$$

\footnotetext{
${ }^{2}$ a derivada local é difinida como a inclinação do segmento de reta que une $N_{1}(t)$ e $N_{1}(t+1)$.
} 
Estudou-se algumas caractarísicas desse crescimento. São elas: (a) o tempo de monte carlo final médio das simulações $\left(T M C_{\text {final }}\right)$; (b) o número total médio de células no tumor final $\left(N f_{\text {total }}\right)$; (c) o ponto máximo da derivada local (DMAX) e (d) o valor de $\eta$, calculado de duas maneiras diferentes como descrito abaixo.

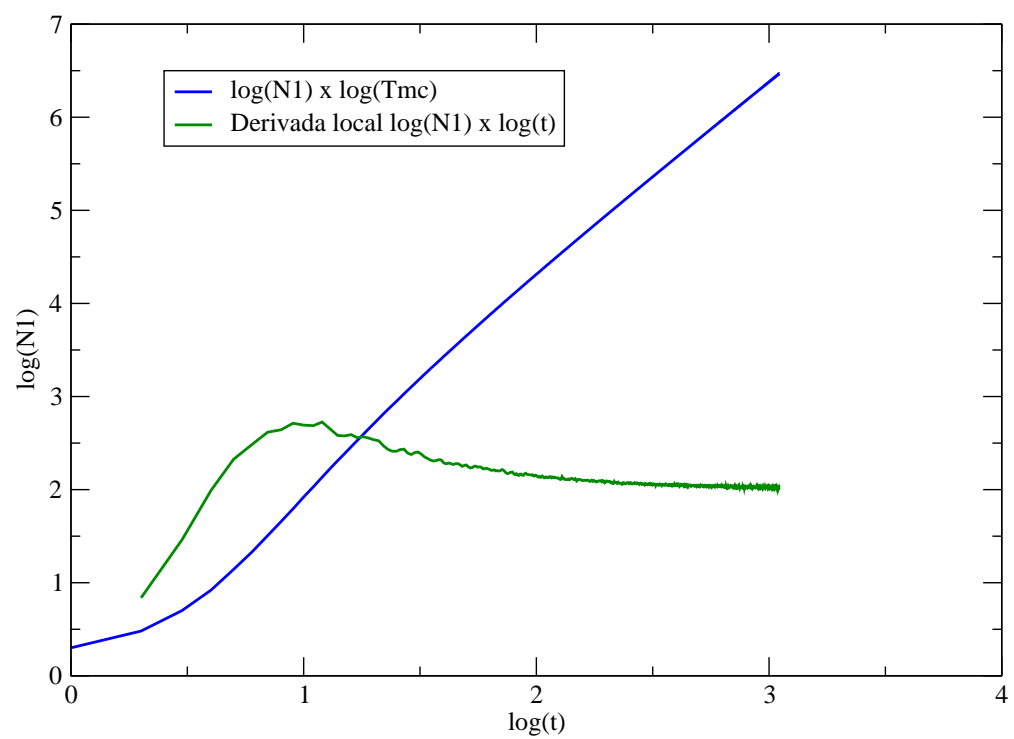

Figura 4.2: Gráfico do logarítmo de $N_{1}(t)$ como função do logarítmo do tempo e sua derivada local, para o modelo nulo 1 . A média foi feita sobre 100 configurações. $\mathrm{MIN}=\mathrm{MAX}=0,5 ; \mathrm{PROBDIF}=\mathrm{PROBANDA}=0$.

O valor de DMAX foi apenas estimado visualmente; o coeficiente $\eta$ da equação (4.2) foi obtido através de dois métodos diferentes. Primeiro considerou-se apenas os últimos 100 pontos da curva da derivada local, ou seja, considerou-se apenas o regime final de crescimento. A partir disso, calculou-se o valor médio desses pontos e o respectivo desvio padrão. O valor calculado dessa forma foi denominado $\eta_{a}$. O outro método empregado para determinar o coeficiente $\eta$ foi calcular a inclinação da reta diretamente da curva 
que descreve a evolução no tempo do número de células do tumor (na escala log-log). A partir dos últimos pontos dessa curva (já no regime estacionário), ajustou-se a melhor reta através do método dos mínimos quadrados. Como há uma incerteza na escolha dos pontos que entrariam no ajuste, considerou-se três conjuntos de pontos, ligeiramente diferentes entre si, todos com cerca de 100 pontos. Para cada um deles ajustou-se a melhor reta. $\eta_{b}$ corresponte a média das inclinações obtidas (o desvio é o desvio padrão da média). Uma comparação dos resultados obtidos para os modelos nulo 1 e nulo 2 com diferentes valores de PROBANDA podem ser vistos na Tabela 1.

\begin{tabular}{l|c|c|c|c}
\hline \hline Medidas & Nulo1 & Nulo2(0,2) & Nulo2(0,5) & Nulo2(0,8) \\
\hline \hline$N f_{\text {total }}$ & $2,96(1)(*)$ & $2,98(1)(*)$ & $2,98(1)(*)$ & $3,00(2)\left(^{*}\right)$ \\
$T M C_{\text {final }}$ & $1139(6)$ & $1226(5)$ & $1468(5)$ & $2210(9)$ \\
$D M A X$ & $(1,0 ; 2,8)$ & $(1,0 ; 3,0)$ & $(1,2 ; 3,3)$ & $(1,7 ; 4,2)$ \\
$\eta_{a}$ & $2,023(4)$ & $2,024(3)$ & $2,027(4)$ & $2,049(5)$ \\
$\eta_{b}$ & $2,0237(3)$ & $2,02374(5)$ & $2,0269(4)$ & $2,0485(4)$ \\
\hline \hline
\end{tabular}

Tabela 1: Algumas características da evolução temporal do número total de células presente no tumor nas simulações do modelo nulo 1 e nulo 2 para os três valores de PROBANDA: 0,$2 ; 0,5$ e $0,8 .\left(^{*}\right) \times 10^{6}$

A figura 4.3 ilustra uma curva típica do modelo nulo 1 para uma dada semente. Percebe-se a inflexão da curva $\log \left(N_{1}\right) \times \log (t)$. As flutuações observadas são parcialmente eliminadas quando se considera a média do resultado obtido para várias sementes.

Uma possível explicação para os dois regimes observados na figura 4.3 é dada pela morfologia do tumor em cada tempo. Para verificar isso, utilizando a interface gráfica descrita anteriormente, investigouse como as células do tumor aparecem antes do ponto de máximo da derivada local, no ponto de máximo e depois deste. Além dessas 
imagens, visualizou-se a imagem do tumor final ao tocar a borda da rede. Essas sequências de imagens são vistas nas figuras 4.4, 4.5 e 4.6 .

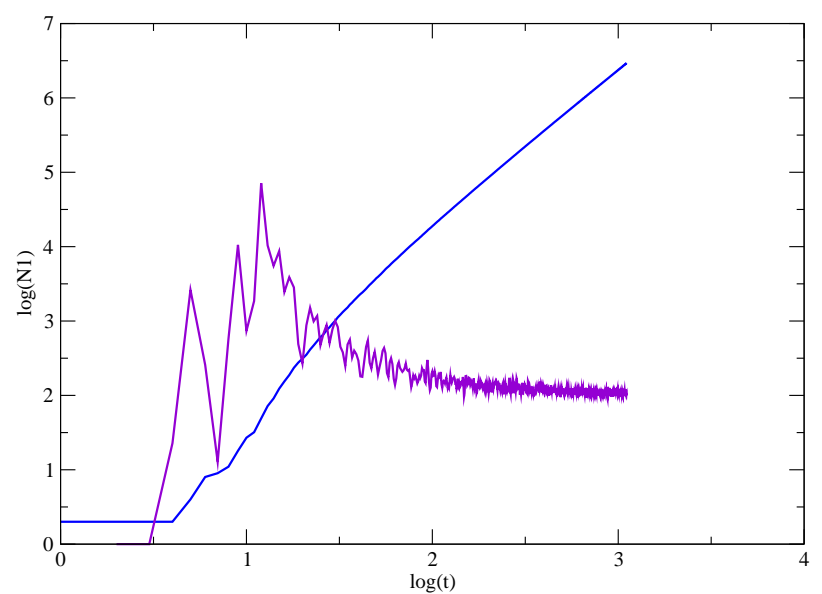

Figura 4.3: $\log \left(N_{1}\right) \times \log (t)$ (curva em azul) e sua respectiva derivada local (curva em roxo) para uma semente particular, no modelo nulo 1. MIN = MAX $=0,5 ; \mathrm{PROBDIF}=\mathrm{PROBANDA}=0$.

A figura 4.4 mostra o tumor nos estágios iniciais de sua formação. Nesse estágio, praticamente todas as células participam do crescimento. Porém, à medida que este cresce, um núcleo de células tumorais parece se formar. As células do núcleo não mais participam do processo de reprodução, pois não tem espaço vazio à sua volta. A atividade do tumor concentra-se em sua borda.

O tumor final apresenta forma qualitativamente muito parecida com o encontrado em $[33,37]$. O aspecto do tumor, ao tocar a borda da rede, é compacto e arredondado. 


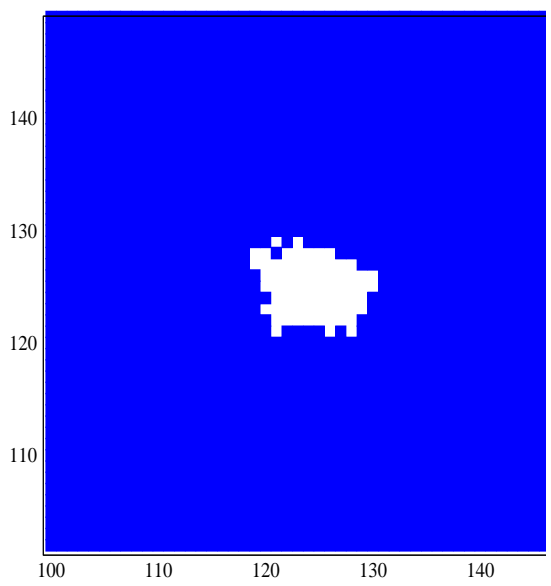

(a) $\mathrm{t}=10$

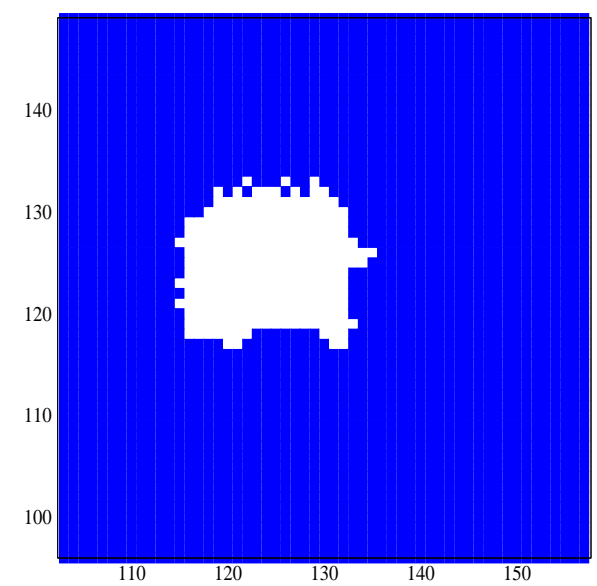

(b) $\mathrm{t}=15$

Figura 4.4: Imagem do tumor em (a) t $=10$ (antes do ponto de máximo) e (b) $\mathrm{t}=15$, no ponto de máximo da derivda local. Valores dos parâmetros usados: $\mathrm{MIN}=\mathrm{MAX}=0,5 ; \mathrm{PROBDIF}=\mathrm{PROBANDA}=0$.

\section{Modelo nulo 2}

O modelo nulo 2 tem um parâmetro a mais (PROBANDA), que controla a motilidade das células. Considerou-se três valores para PROBANDA: 0,2, 0, 5 e 0,8. Para cada um deles obteve-se $N_{1,2}(t)$. Novamente, médias foram feitas sobre as cem simulações, com os mesmos parâmetros, mas com diferentes sementes aleatórias. Observouse essencialmente o mesmo comportamento para o crescimento do tumor que o observado no modelo nulo 1. Inicialmente, há um período transiente, variável conforme o valor do PROBANDA, e, passado esse período, a curva comporta-se como uma lei de potência, de acordo com 4.2. Esse comportamento parece ser uma espécie de assinatura do modelo e foi observado também em todos os outros casos estudados (modelo completo com $L R_{\text {constante }}, L R_{\text {cres }}$ e $L R_{\text {decres }}$ ).

A figura 4.7 mostra o gráfico de $N_{2}(t)$, em escala log-log, para os três valores de PROBANDA estudados. A figura 4.8 mostra as derivadas locais dessas curvas juntamente com a do modelo nulo 1, 


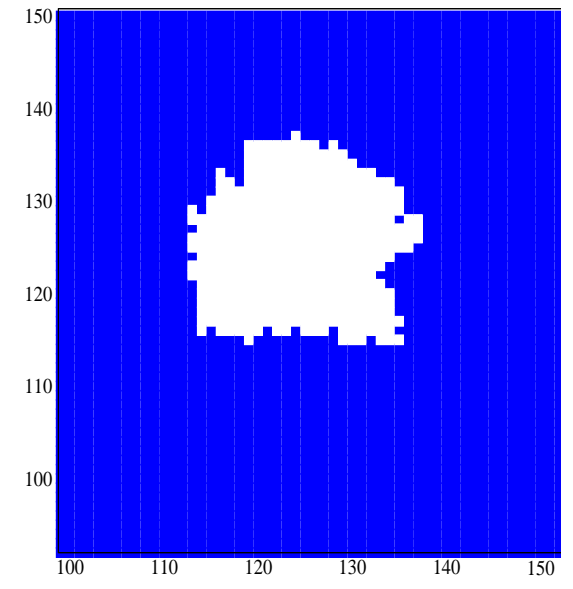

(a) $\mathrm{t}=18$

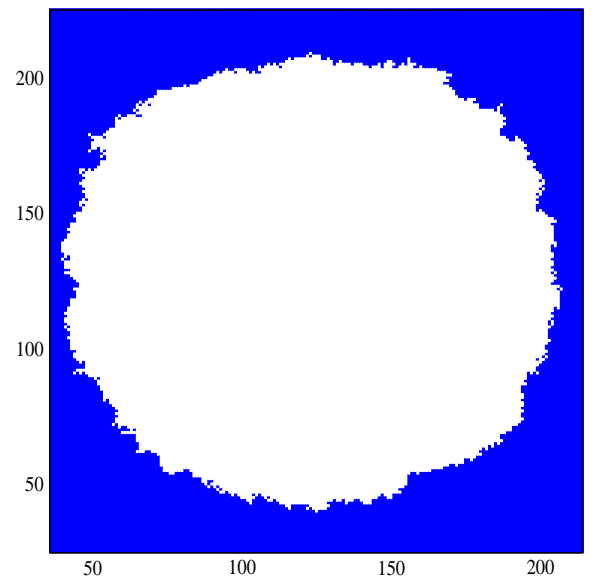

(b) $\mathrm{t}=100$

Figura 4.5: Imagem do tumor nos instantes (a) t=18 (logo após o máximo) e (b) $\mathrm{t}=100$ (muito tempo depois do ponto de máximo). Valores dos parâmetros usados: $\mathrm{MIN}=\mathrm{MAX}=0,5 ; \mathrm{PROBDIF}=\mathrm{PROBANDA}=0$.

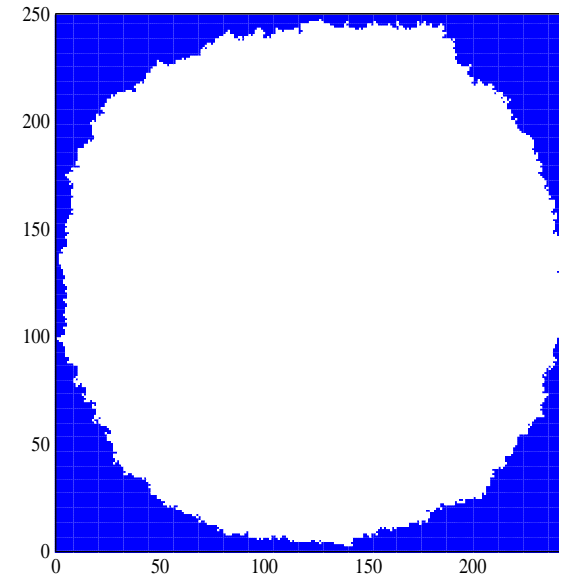

(a) Tumor ao tocar na borda

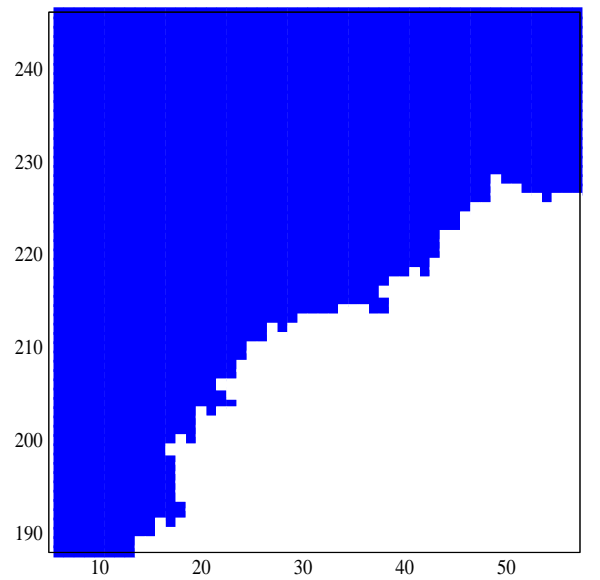

(b) Detalhe de (a)

Figura 4.6: (a) Imagem do tumor ao tocar na borda da rede. Nota-se o aspecto compacto e arrendondado. Em (b) vemos uma amplicação de (a), onde se pode observar com mais detalhe a borda do tumor. Valores dos parâmetros usados: $\mathrm{MIN}=\mathrm{MAX}=0,5 ; \mathrm{PROBDIF}=\mathrm{PROBANDA}=0$. 
para efeito de comparação.

Na figura 4.8, verifica-se que o instante $t$ onde ocorre a mudança de regime (onde ocorre o máximo da derivada local) bem como o número de células presente nos tumores nesse instante é alterado se o valor do PROBANDA muda. Quanto maior o valor de PROBANDA, maior o número de células presentes no tumor no ponto de inflexão.

Por construção do modelo, se PROBANDA $\neq 0$, há um atraso no tempo necessário para que o tumor atinja um certo tamanho, o que fica evidente na figura 4.8. Isso ocorre porque o algoritmo do programa é tal que a rotina da reprodução é executada só se a célula tumoral não se move (ou seja, se o número aleatório sorteado for maior que o PROBANDA). Dessa forma, quanto maior é o valor de PROBANDA, maior o tempo necessário para que um certo número de células se reproduza. Para verificar se o deslocamento do ponto de máximo era uma consequência (artificial) do algoritmo empregado, preocedeu-se a um re-escalonamento do tempo.

Sabe-se que, no modelo nulo 1, todas as células da rede, em média, têm chance de reproduzir-se uma vez a cada intervalo de tempo (tempo de Monte Carlo). Nos casos em que PROBANDA é diferente de zero, somente (1-PROBANDA) células têm essa chance no mesmo intervalo de tempo. A mudança de escala em t foi realizada, portanto, multiplicando-se o tempo pelo fator $(1-P R O B$ $A N D A)$. A figura 4.9 reproduz a figura 4.8 com essa alteração na escala de tempo, mostrando que, de fato, o máximo da derivada local ocorre aproximadamente no mesmo momento para todos os valores de PROBANDA (em torno de $t=10$ passos de monte carlo). 


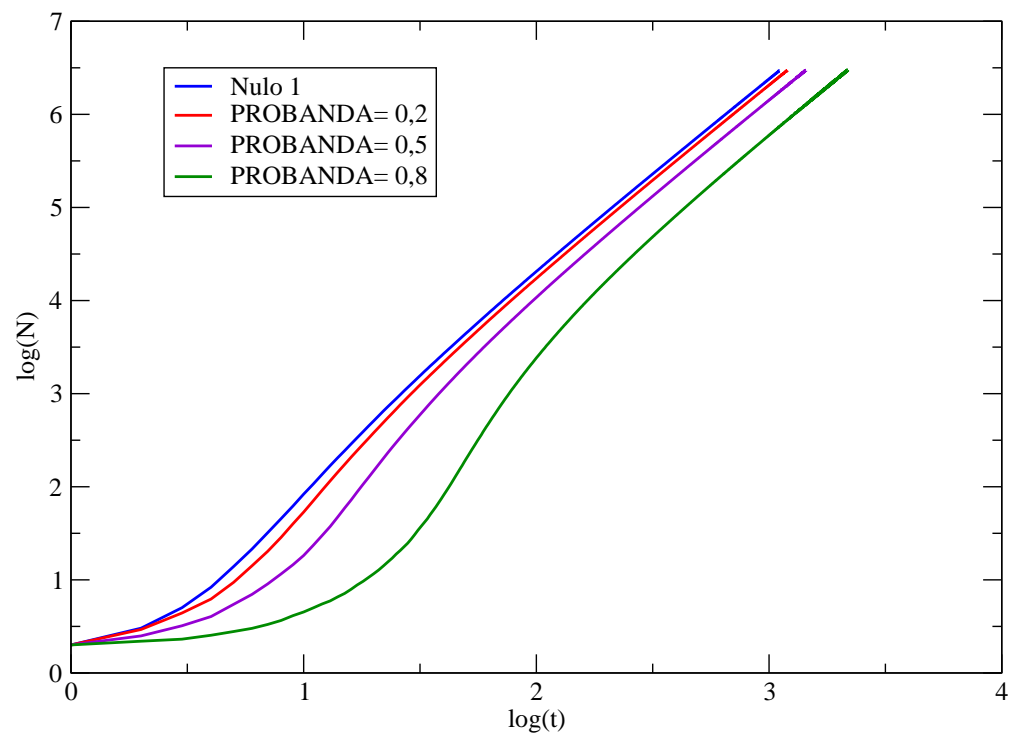

Figura 4.7: Gráfico de $\log \left(N_{2}(t)\right) \times \log (t)$ para o modelo nulo 2. PROBANDA $=0$ (nulo 1) e PROBANDA $=0,2 ; 0,5$ e 0,8 (nulo 2). Em todos os casos $\mathrm{MIN}=\mathrm{MAX}=0,5$ e PROBDIF $=0$.

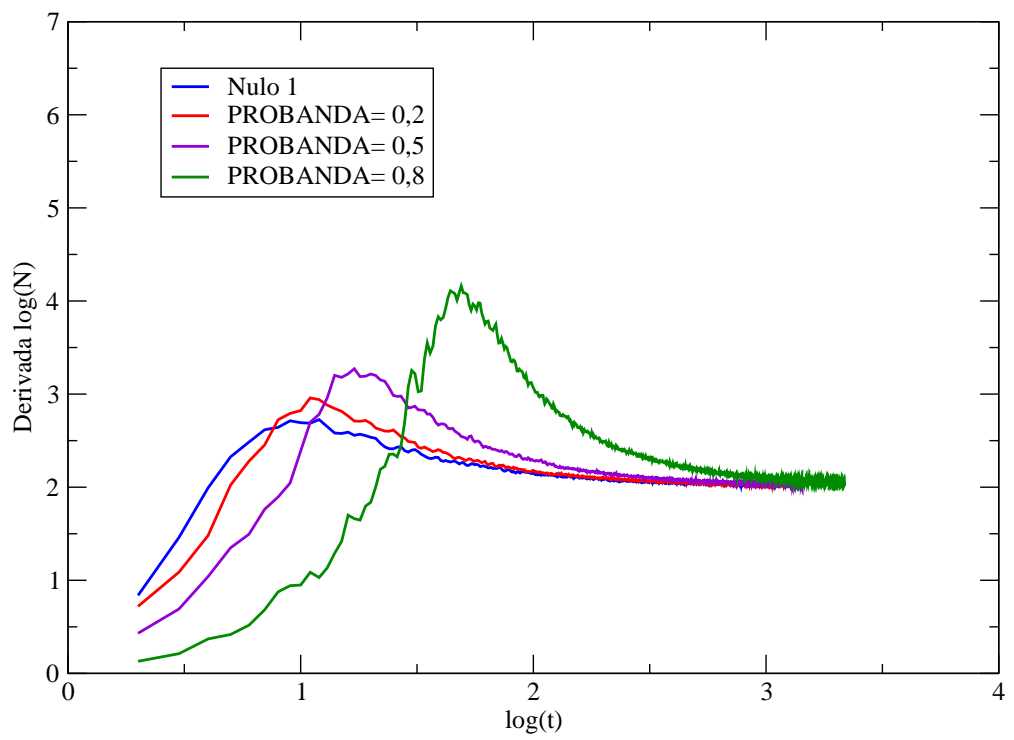

Figura 4.8: Derivada local de $\log \left(N_{2}(t)\right) \times \log (t)$ para PROBANDA $=0$ (nulo 1 ) e $\mathrm{PROBANDA}=0,2 ; 0,5$ e 0,8 (nulo 2). Em todas as simulações $\mathrm{MIN}=$ $\mathrm{MAX}=0,5$ e $\mathrm{PROBDIF}=0$. 


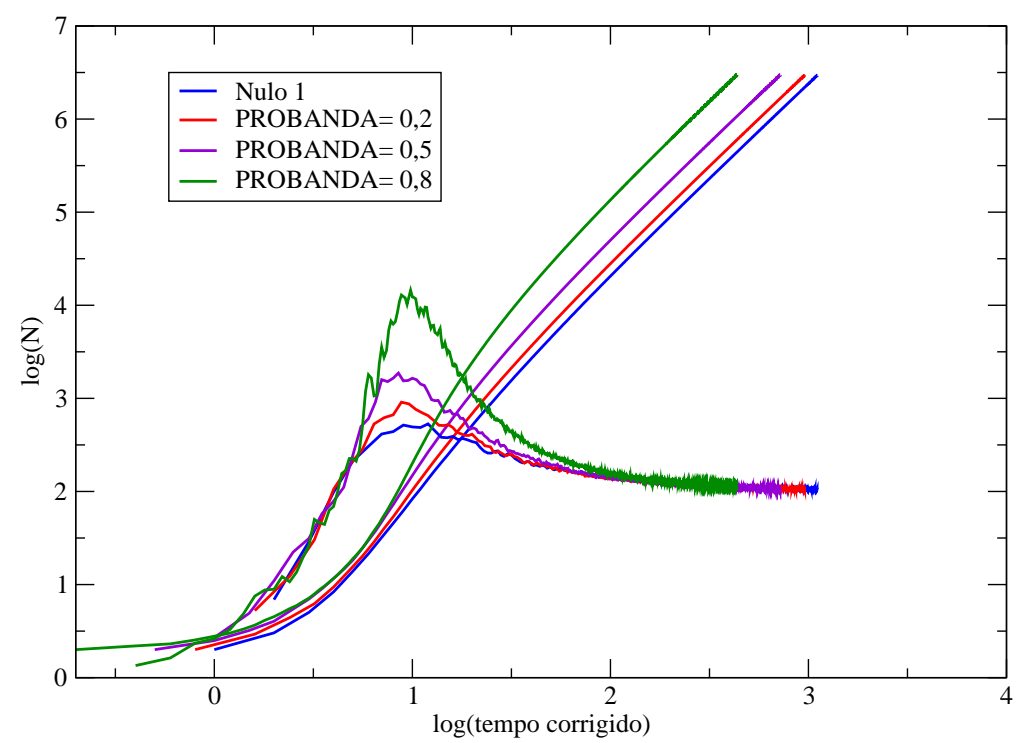

Figura 4.9: Gráfico de $\left.\log \left(<N_{2}(t)\right\rangle\right) \times \log (t)$ para o modelo nulo 2, para PROBANDA $=0$ (nulo 1$)$ e PROBANDA $=0,2 ; 0,5$ e 0,8 (nulo 2). $\mathrm{O}$ tempo foi re-escalado como descrito no texto. Comparar com os resultados apresentados nas figuras 4.7 e 4.8. $\mathrm{MIN}=\mathrm{MAX}=0,5$ e $\mathrm{PROBDIF}=0$.

Estudou-se também o crescimento dos modelos nulos através da evolução no tempo da fração de células que se reproduzia em cada passo de tempo, ou seja, estudou-se a evolução no tempo de

$$
\frac{\langle N(t+1)\rangle-\langle N(t)\rangle}{\langle N(t)\rangle}
$$

denominada daqui para a frente taxa de crescimento. A figura 4.10 mostra o resultado dessa análise em escala monolog e a figura 4.11 na escala log-log. A existência dos dois regimes é ainda mais evidente. Observa-se um crescimento exponencial no início, provavelmente quando todas as células do tumor ainda podem se reproduzir. Depois a fração de células que se reproduz cai com 1/t. Como $N \sim t^{2}$, isso significa que o crescimento passou a ser dominado pelo número de células tumorais na superfície do tumor. 


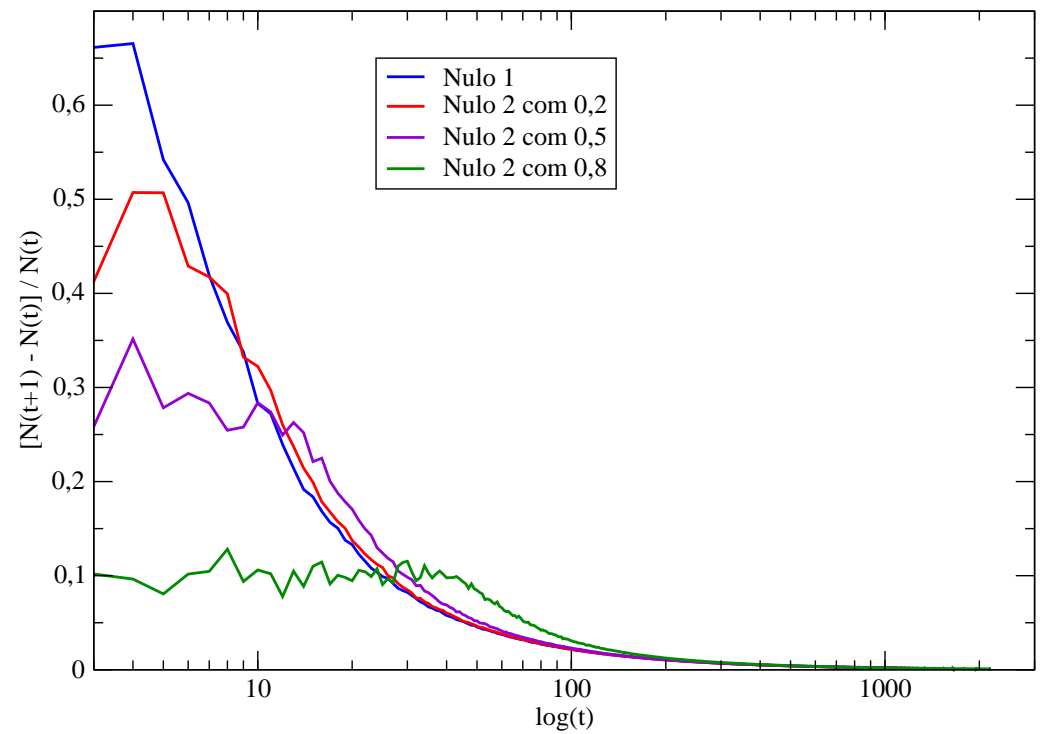

Figura 4.10: Gráfico, na escala monolog, da taxa de crescimento versus tempo para diferentes valores de PROBANDA (modelos nulos).

As mesmas grandezas empregadas para caracterizar o comportamento do modelo nulo 1 foram empregadas para caracterizar o modelo nulo 2. Essas medidas também estão na Tabela 1. Quando comparado com o modelo nulo 1, percebe-se uma ligeira mudança no comportamento assintótico. Para PROBANDA igual a 0,2 , as mudanças não são perceptíveis. Entretanto, aumentando-se o valor de PROBANDA, observa-se um pequeno aumento no coeficiente $\eta$. A figura 4.12 exibe um gráfico de $\eta$ como função de PROBANDA.

Em relação ao aumento do número médio de células no tumor final para $\mathrm{PROBANDA}=0,8$, não se pode atribuir isso ao efeito da difusão, levando-se em conta os desvios padrões dessas medidas.

Para relacionar o efeito da difusão das células com a morfologia do tumor, analisou-se o modelo com PROBANDA $=0,8$ para uma certa 


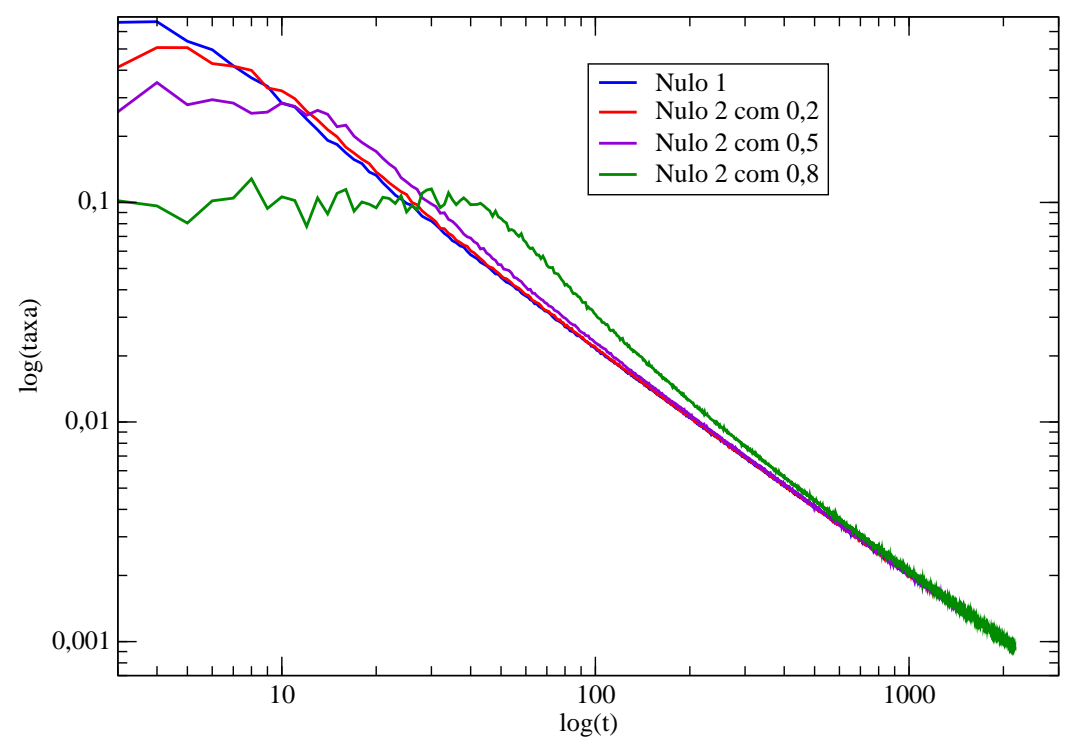

Figura 4.11: Gráfico, na escala log-log, da taxa de crescimento versus tempo para diferentes valores de PROBANDA (modelos nulos).

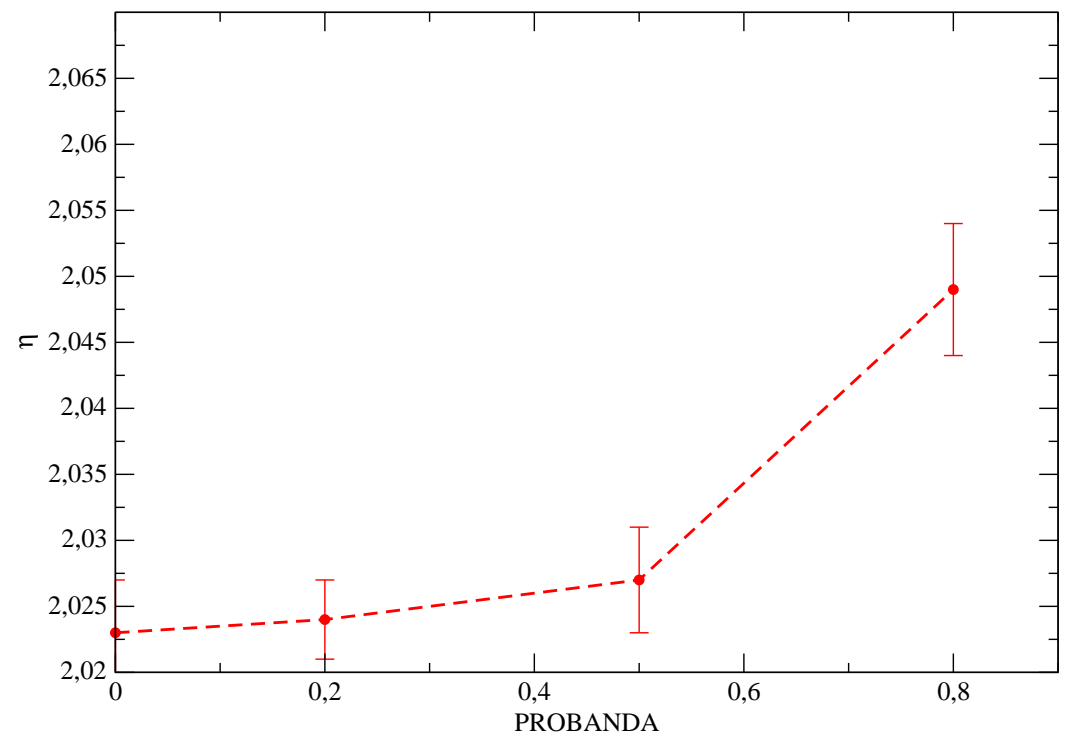

Figura 4.12: $\eta$ versus PROBANDA, que mostra como a motilidade da célula tipo 2 afeta o crescimento do tumor. 
semente. O gráfico, na escala $\log -\log$, de $N_{2}(t)$, para essa semente é visto na figura 4.13. De forma análoga ao que foi feito para o modelo nulo 1, visualizou-se o tumor nos estágios iniciais do crescimento, antes do ponto de inflexão, na região do ponto de inflexão e depois do ponto de inflexão. Os padrões morfológicos obtidos nesses estágios de desenvolvimento estão ilustrados nas figuras 4.14, 4.15 e 4.16.

Os padrões observados diferem dos obtidos no modelo nulo1 em alguns aspectos importantes. O principal deles é a existência de células tumorais desconexas no início e uma superfície bem mais rugosa no estado estacionário (embora, aparentemente, não haja células desconectadas do tumor principal). A atividade do tumor (uma célula ativa é uma célula que tem pelo menos um espaço vazio na sua vizinhança, de modo que ainda pode se reproduzir) não está mais restrita à superfície, localizando-se em uma camada com espessura não desprezível. No entanto ainda observa-se, no estado estacionário, o aparecimento de um núcleo compacto inativo e de uma forma simétrica e arredondada. Uma superfície com dimensão fractal $>2$ pode eventualmente explicar o aumento do coeficiente $\eta$, mas por falta de tempo esse ponto não foi ainda investigado. As figuras 4.14, 4.15 e 4.16 exemplificam essa evolução.

\subsubsection{Estudo do Modelo Completo}

Uma vez feita a análise dos modelos nulos, partiu-se para o estudo do modelo completo, que leva em conta dois outros mecanismos: a diferenciação celular (introduzida quando PROBDIF $\neq 0$ ) e uma possível relação entre a taxa de reprodução e a topologia do tumor 


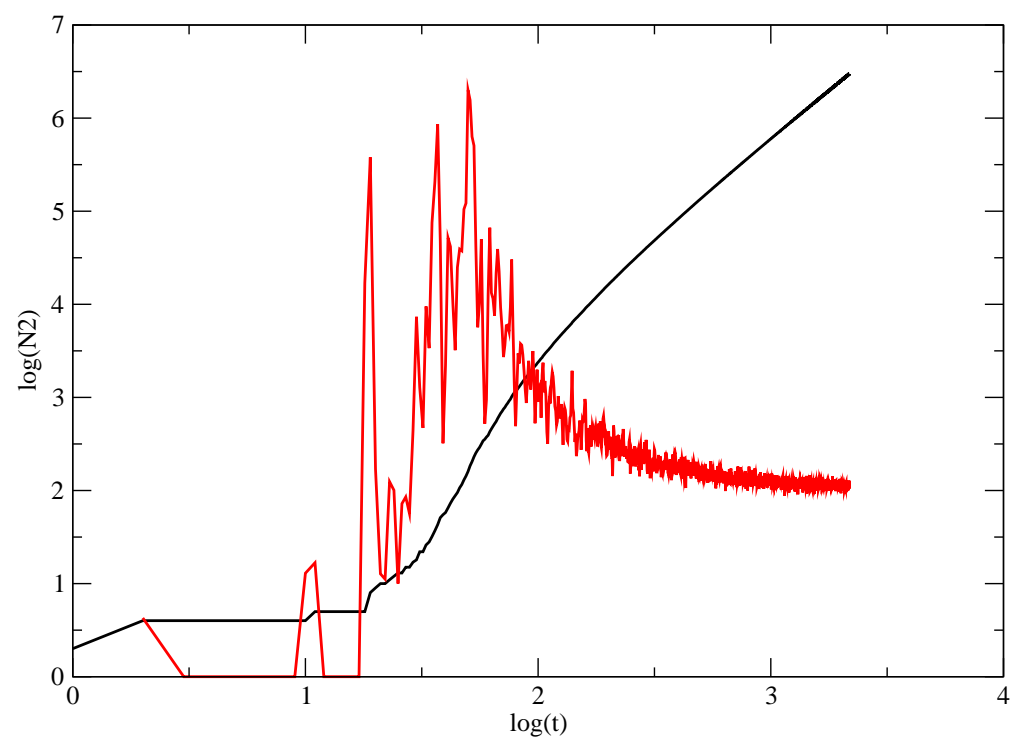

Figura 4.13: $\log \left(N_{2}(t)\right) \times \log (t)$ (curva em preto) e sua respectiva derivada local (curva em vermelho) para uma semente específica. Durante o período transiente, observa-se que as flutuações são bem maiores que as observadas na figura 4.3. $\mathrm{MIN}=\mathrm{MAX}=0,5, \mathrm{PROBDIF}=0$ e PROBANDA $=0,8$.

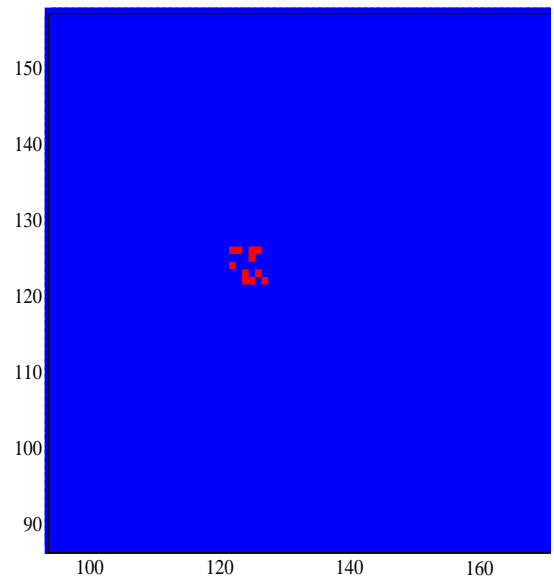

(a) $t=20$

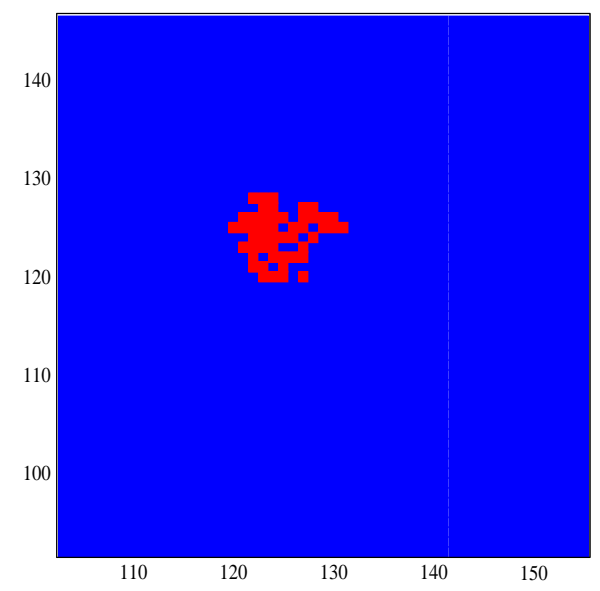

(b) $\mathrm{t}=35$

Figura 4.14: Imagem do tumor (a) antes do ponto de inflexão ( $t=20)$ e (b) no início da inflexão $(t=35)$. Inicialmente, as células do tumor estão dispersas. À medida que o tumor cresce, as células formam um núcleo, mas ainda observase inúmeros sítios vazios presentes na borda do tumor. $\mathrm{MIN}=\mathrm{MAX}=0,5$, $\mathrm{PROBDIF}=0$ e PROBANDA $=0,8$. 


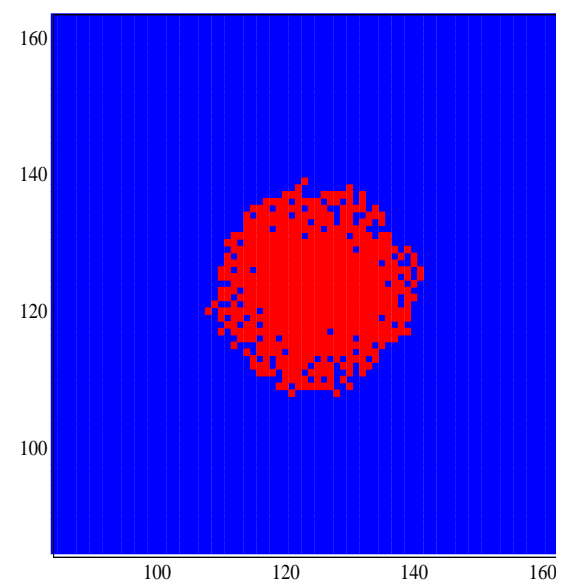

(a) $t=65$

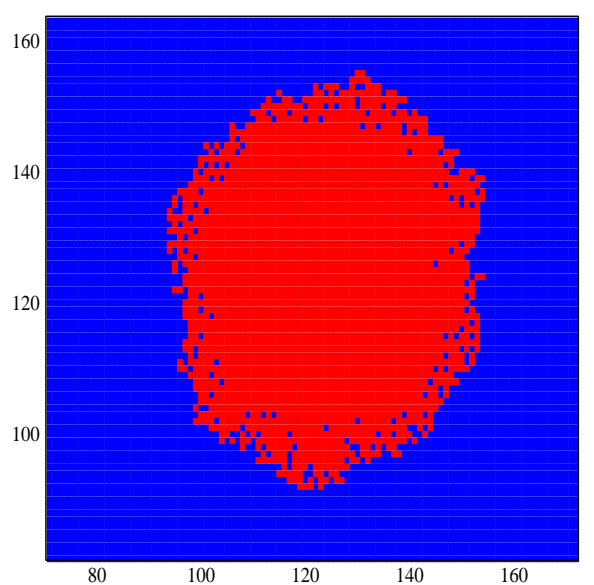

(b) $\mathrm{t}=100$

Figura 4.15: (a) Tumor na região do ponto de inflexão $(\mathrm{t}=65)$. O núcleo é mais compacto mas a irregularidade continua presente na periferia do tumor. (b) Tumor em um instante posterior ao ponto de inflexão $(\mathrm{t}=100)$. MIN $=$ MAX $=0,5, \operatorname{PROBDIF}=0$ e PROBANDA $=0,8$.

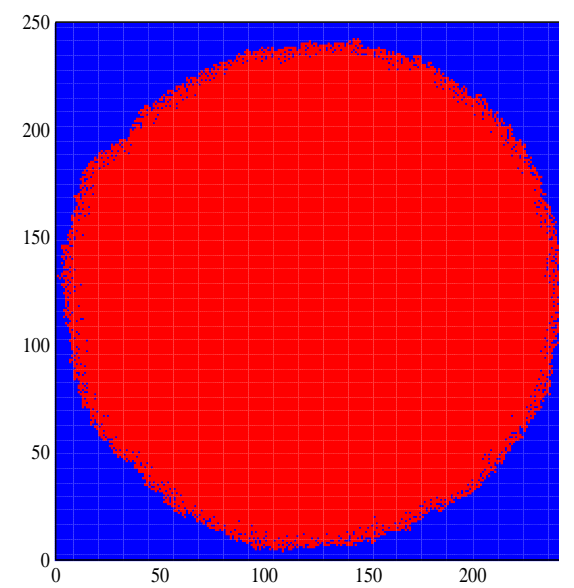

(a) Tumor ao tocar a borda

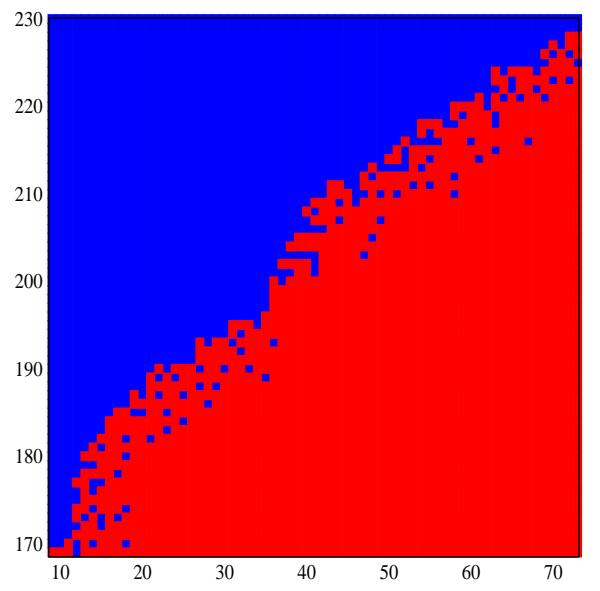

(b) Detalhe de (a)

Figura 4.16: (a) Tumor no instante em que toca na borda. (b) Ampliação de (a), mostrando os detalhes da borda do tumor. Esse aspecto não é visto na figura 4.6, equivalente ao modelo de Eden. $\mathrm{MIN}=\mathrm{MAX}=0,5, \mathrm{PROBDIF}=0$ e $\operatorname{PROBANDA}=0,8$. 
na vizinhança da célula (introduzida pelos diferentes perfis da função Limiar de Reprodução).

As simulações iniciaram-se sempre com duas células (uma tipo 1 e outra tipo 2 ) nos sítios $(1000,1000)$ e $(1000,1001)$ respectivamente, e, novamente, os resultados apresentados referem-se à média sobre 100 realizações do modelo. PROBDIF foi mantido constante e igual a 0,5 . Para cada valor de PROBANDA estudado $(0,2 ; 0,5$ e 0,8$)$, considerou-se cada uma das três funções LR já descritas (função crescente, decrescente e constante). Como agora há dois tipos de células, estudou-se a evolução no tempo do número de células tipo $1\left(N_{1}(t)\right)$, do número de células tipo $2\left(N_{2}(t)\right)$ e do número total de células $\left(N(t)=N_{1}(t)+N_{2}(t)\right)$. Por simplicidade, não se considerou o tempo corrigido. As figuras 4.17 a 4.25 mostram os resultados obtidos para $N_{1}(t), N_{2}(t)$ e $N(t)$, bem como suas derivadas locais. $N(t)$ para o modelo nulo 2 com $L R_{\text {constante }}$ foi incluído nestas figuras com o objetivo de facilitar a comparação.

Em seguida, como nos modelos nulos, estudou-se algumas propriedades médias desse conjunto de simulações. Os resultados são exibidos nas Tabelas 2, 3 e 4 . O número médio de células de um dado tipo no tumor final $\left(N f_{1}\right.$ para tipo $1 ; N f_{2}$ para tipo 2 e $N f$ para o total de células) e seus respectivos desvios padrões foram medidos, assim como o coeficiente $\eta$ que caracteriza o comportamento estacionário de cada curva. O método utilizado para a determinação desses coeficientes foi o mesmo descrito nos modelos nulos, denomidado $\eta_{a}$. Denotou-se $\eta$ para o coeficiente referente à curva $\log (N) \times \log (t), \eta_{1}$ para a curva $\log \left(N_{1}\right) \times \log (t)$ e $\eta_{2}$ para $\log \left(N_{2}\right) \times \log (t)$. Também foi estimado visualmente o ponto de máximo da derivada local dessas curvas, quando estes existiam. Esses pontos foram denominados $D M A X_{N}, D M A X_{N 1}$ e $D M A X_{N 2}$ 
respectivamente.

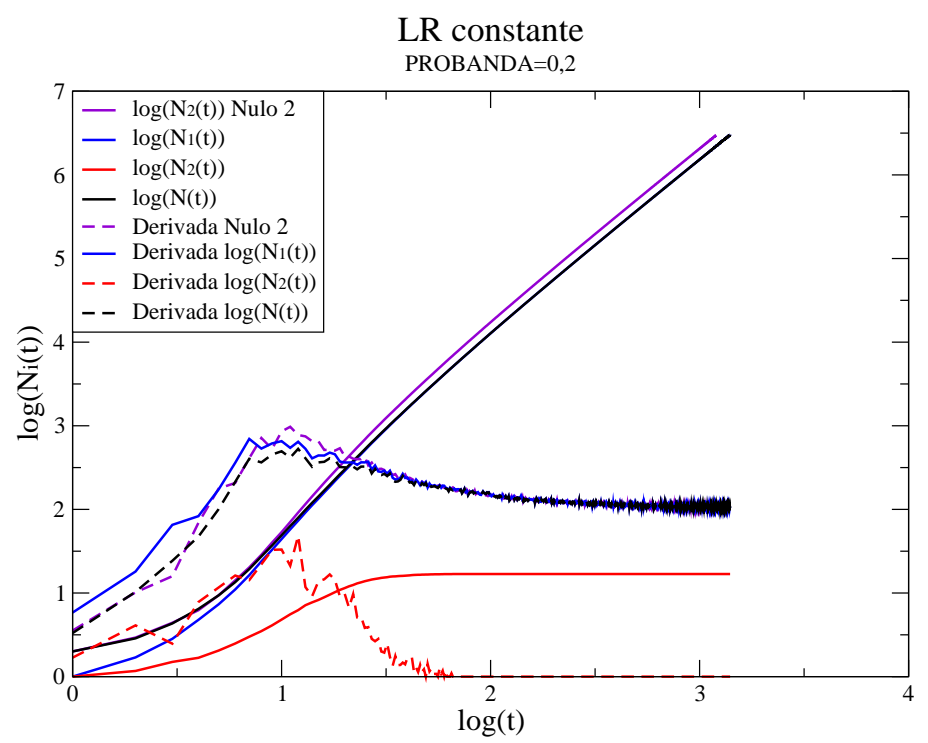

Figura 4.17: Gráficos de $\log (N(t)), \log \left(N_{1}(t)\right)$ e $\log \left(N_{2}(t)\right)$ como função de $\log (t)$ e suas respectivas derivadas locais para PROBANDA $=0,2$ e Limiar de Reprodução constante. No modelo completo, $\mathrm{PROBDIF}=0,5$; no modelo nulo 2, PROBDIF $=0$. O gráfico do modelo nulo 2 para $P R O B A N D A=0,2$ foi incluído para facilitar a comparação entre os resultados.

\begin{tabular}{l|l|l|l}
\hline \hline Medidas & $L R_{\text {const }}(\mathbf{0 , 2})$ & $L R_{\text {const }}(\mathbf{0 , 5})$ & $L R_{\text {const }}(\mathbf{0 , 8})$ \\
\hline \hline$N f$ & $3,02\left(^{*}\right) \pm 0,01\left(^{*}\right)$ & $2,85\left(^{*}\right) \pm 0,02\left(^{*}\right)$ & $2,9\left(^{*}\right) \pm 0,3\left(^{*}\right)$ \\
$N f_{1}$ & $3,02\left(^{*}\right) \pm 0,01\left(^{*}\right)$ & $2,85\left(^{*}\right) \pm 0,02\left(^{*}\right)$ & $2,1\left(^{*}\right) \pm 0,2\left(^{*}\right)$ \\
$N f_{2}$ & $17 \pm 21$ & $789 \pm 1108$ & $8\left(^{* *}\right) \pm 1\left(^{* *}\right)$ \\
$D M A X_{N}$ & $(1,1 ; 2,7)$ & $(1,4 ; 2,8)$ & - \\
$D M A X_{N 1}$ & $(0,9 ; 2,8)$ & $(1,42,8)$ & - \\
$D M A X_{N 2}$ & $(1,1 ; 1,7)$ & $(1,5 ; 2,2)$ & $(2,2 ; 3,5)$ \\
$\eta$ & $2,022 \pm 0,004$ & $2,017 \pm 0,005$ & $2,076 \pm 0,007$ \\
$\eta_{1}$ & $2,022 \pm 0,004$ & $2,022 \pm 0,004$ & $2,072 \pm 0,009$ \\
$\eta_{2}$ & 0 & $0,04 \pm 0,04$ & $2,09 \pm 0,01$ \\
\hline \hline
\end{tabular}

Tabela 2: Tabela com as propriedades estudadas nas simulações com a função $L R_{\text {constante }}$, para PROBANDA $=0,2,0,5$ e $0,8 .\left(^{*}\right) \times 10^{6}(* *) \times 10^{5}$ 


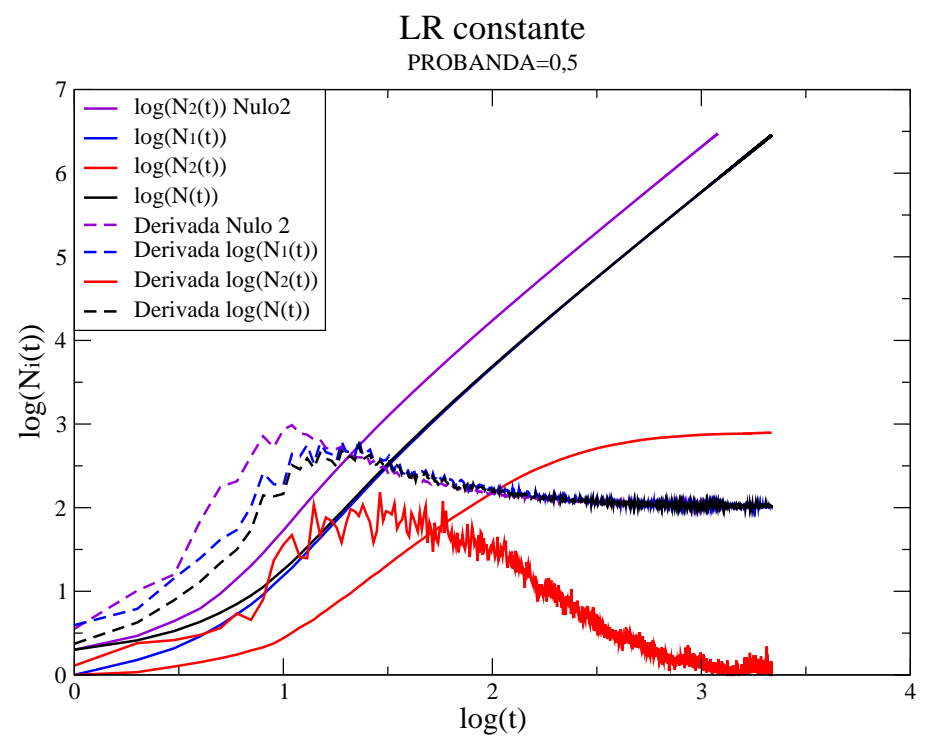

Figura 4.18: Gráficos de $\log (N(t)), \log \left(N_{1}(t)\right) \log \left(N_{2}(t)\right)$ como função de $\log (t)$ e suas respectivas derivadas locais para PROBANDA $=0,5$ e Limiar de Reprodução constante. No modelo completo, $\mathrm{PROBDIF}=0,5$; no modelo nulo 2, $\operatorname{PROBDIF}=0$. O gráfico do modelo nulo 2 para $P R O B A N D A=0,5$ foi incluído para facilitar a comparação entre os resultados.

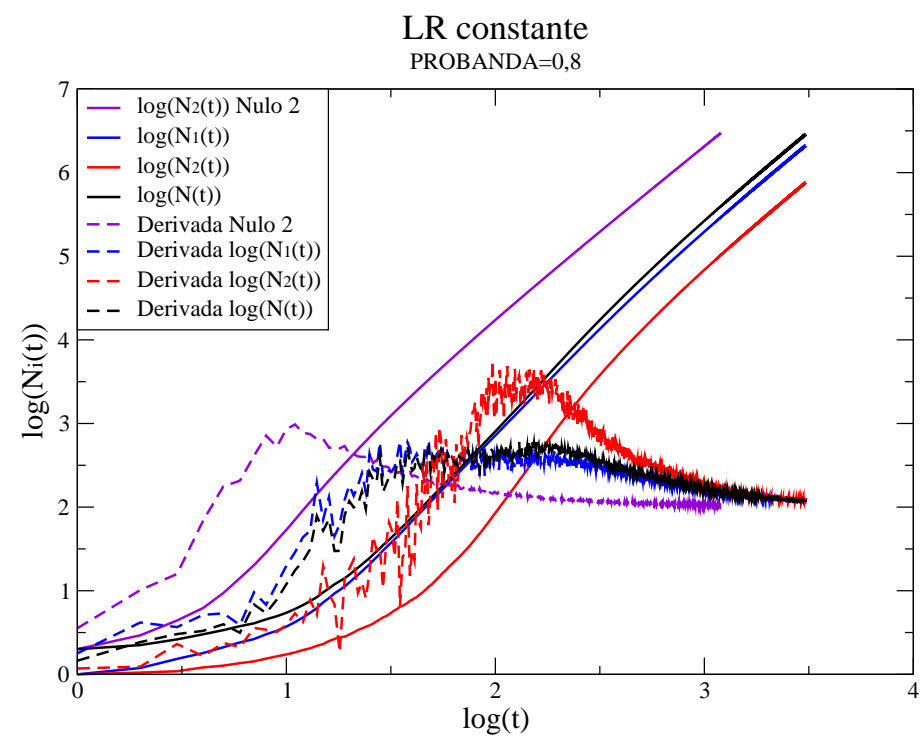

Figura 4.19: Gráficos de $\log (N(t)), \log \left(N_{1}(t)\right)$ e $\log \left(N_{2}(t)\right)$ como função de $\log (t)$ e suas respectivas derivadas locais para PROBANDA $=0,8$ e Limiar de Reprodução constante. No modelo completo, $\mathrm{PROBDIF}=0,5$; no modelo nulo 2, PROBDIF $=0$. O gráfico do modelo nulo 2 para $P R O B A N D A=0,8$ foi incluído para facilitar a comparação dos resultados. 


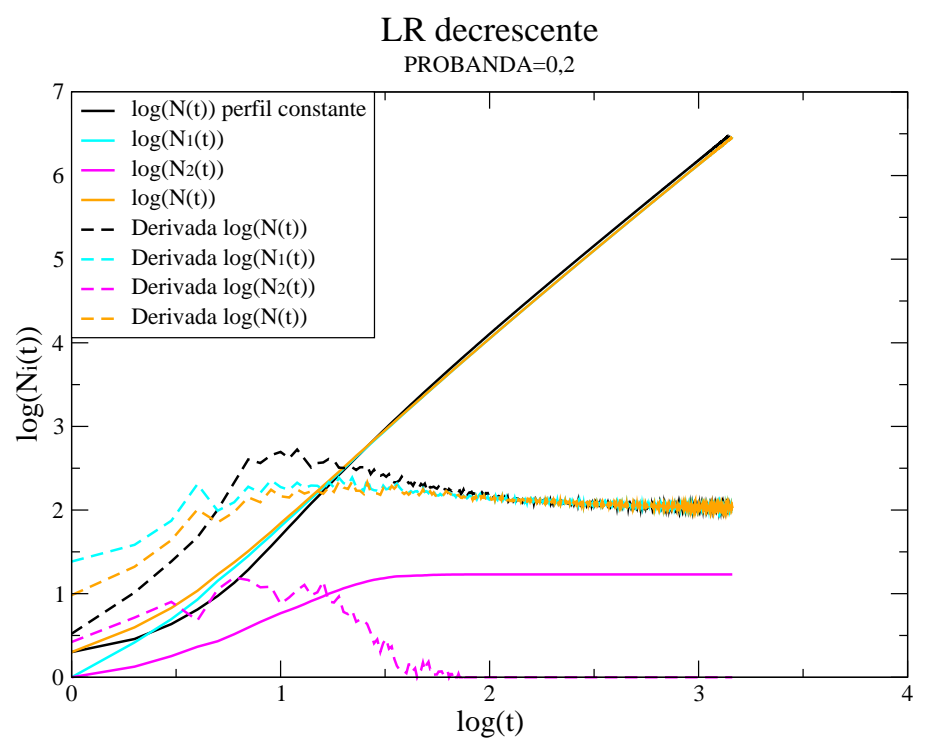

Figura 4.20: Gráficos de $\log (N(t)), \log \left(N_{1}(t)\right)$ e $\log \left(N_{2}(t)\right)$ como função de $\log (t)$ e suas respectivas derivadas locais para PROBANDA $=0,2$ e Limiar de Reprodução decrescente. No modelo completo, $\mathrm{PROBDIF}=0,5$. O gráfico do perfil constante para $P R O B A N D A=0,2$ foi incluído para facilitar a comparação dos resultados.

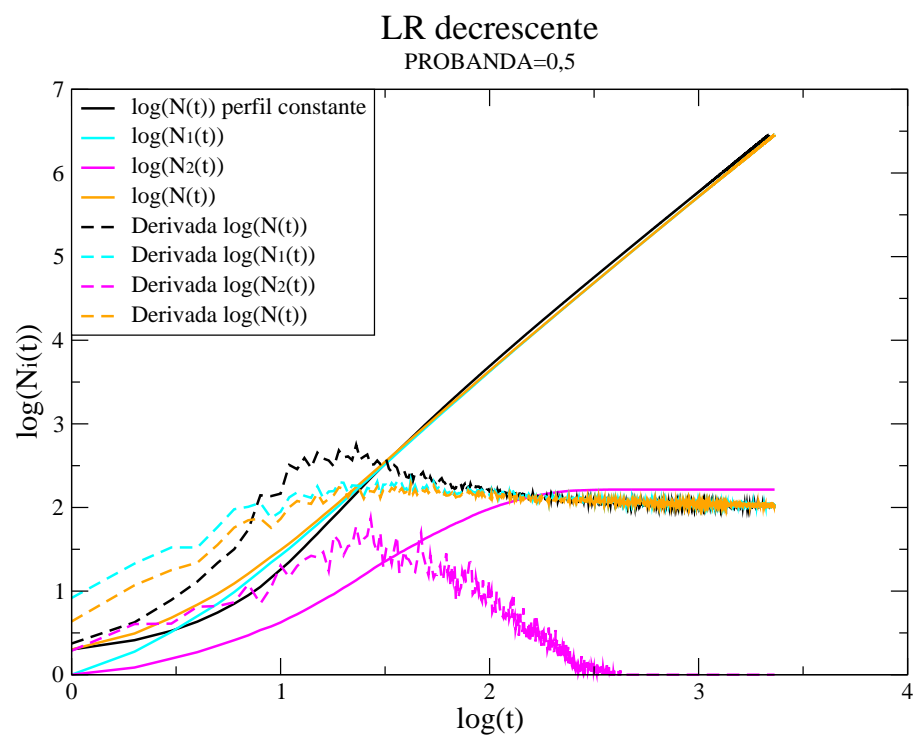

Figura 4.21: Gráficos de $\log (N(t)), \log \left(N_{1}(t)\right)$ e $\log \left(N_{2}(t)\right)$ como função de $\log (t)$ e suas respectivas derivadas locais para PROBANDA $=0,5$ e Limiar de Reprodução decrescente. No modelo completo, $\mathrm{PROBDIF}=0,5 . \quad \mathrm{O}$ gráfico do perfil constante para $P R O B A N D A=0,5$ foi incluído para facilitar a comparação dos resultados. 


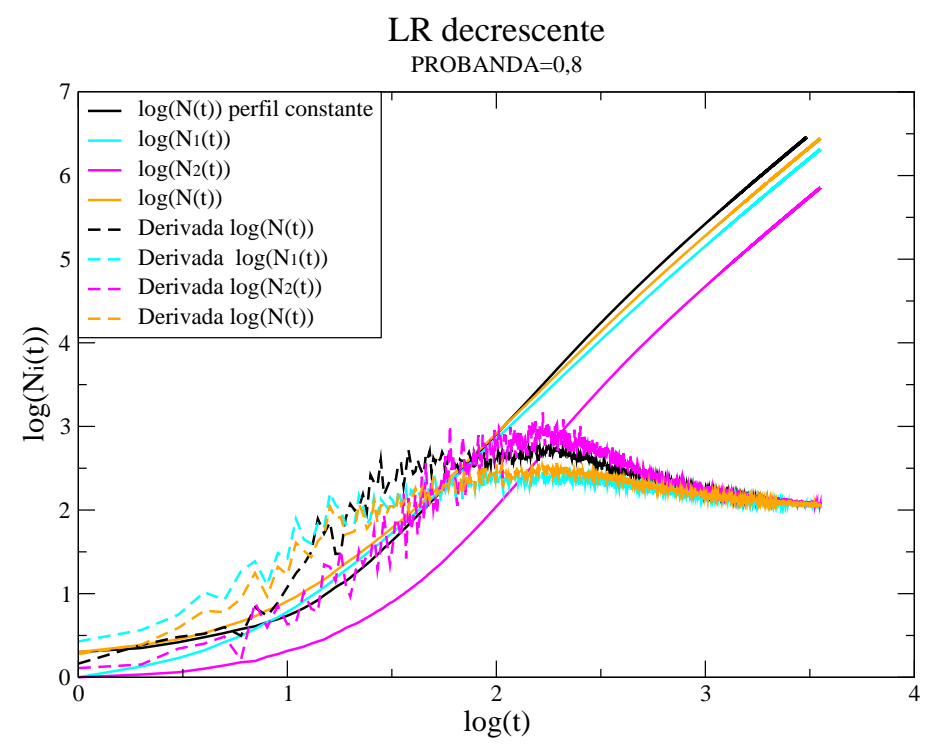

Figura 4.22: Gráficos de $\log (N(t)), \log \left(N_{1}(t)\right)$ e $\log \left(N_{2}(t)\right)$ como função de $\log (t)$ e suas respectivas derivadas locais para PROBANDA $=0,8$ e Limiar de Reprodução decrescente. No modelo completo, $\mathrm{PROBDIF}=0,5 . \mathrm{O}$ gráfico do perfil constante para $P R O B A N D A=0,8$ foi incluído para facilitar a comparação dos resultados.

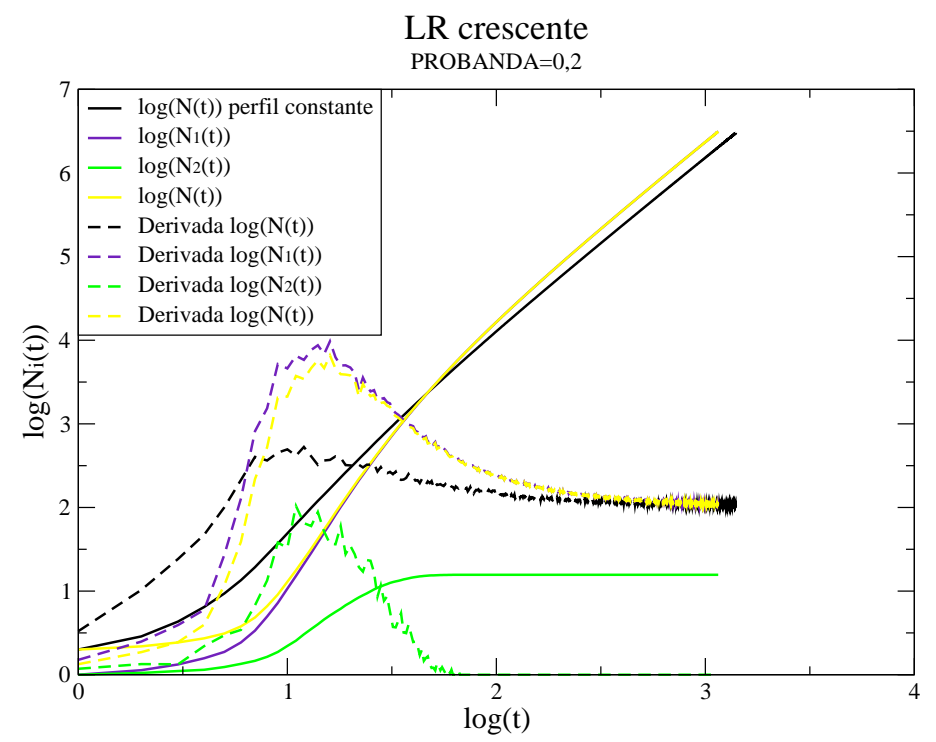

Figura 4.23: Gráficos de $\log (N(t)), \log \left(N_{1}(t)\right)$ e $\log \left(N_{2}(t)\right)$ como função de $\log (t)$ e suas respectivas derivadas locais para PROBANDA $=0,2$ e Limiar de Reprodução crescente. No modelo completo, $\mathrm{PROBDIF}=0,5$. O gráfico do perfil constante para $P R O B A N D A=0,2$ foi incluído para facilitar a comparação dos resultados. 


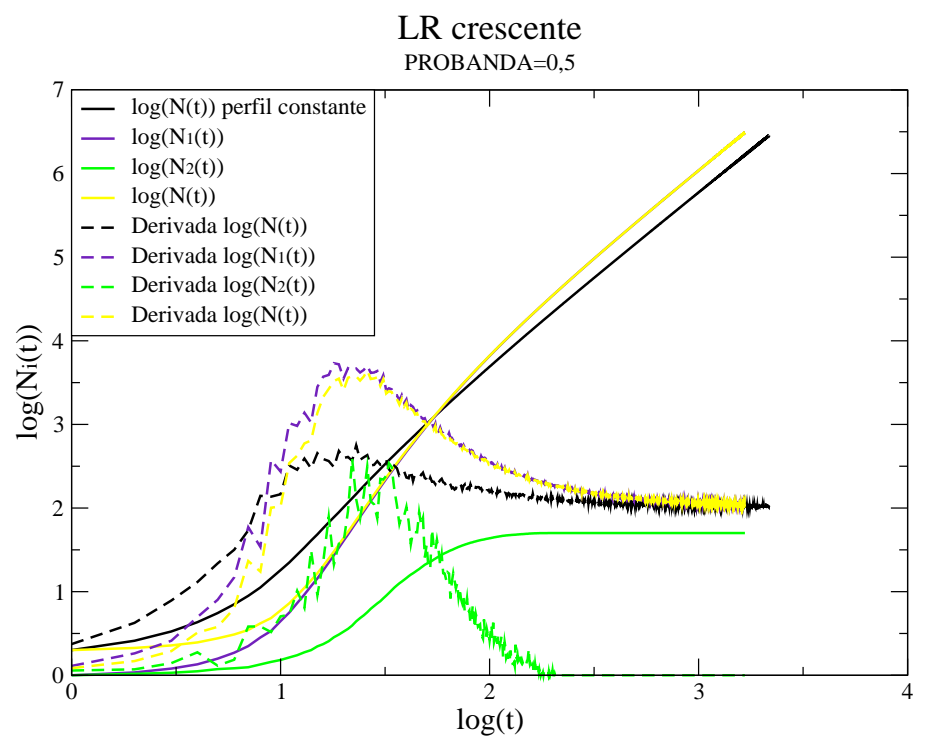

Figura 4.24: Gráficos de $\log (N(t)), \log \left(N_{1}(t)\right)$ e $\log \left(N_{2}(t)\right)$ como função de $\log (t)$ e suas respectivas derivadas locais para PROBANDA $=0,5$ e Limiar de Reprodução crescente. No modelo completo, $\mathrm{PROBDIF}=0,5$. O gráfico do perfil constante para $P R O B A N D A=0,5$ foi incluído para facilitar a comparação dos resultados.

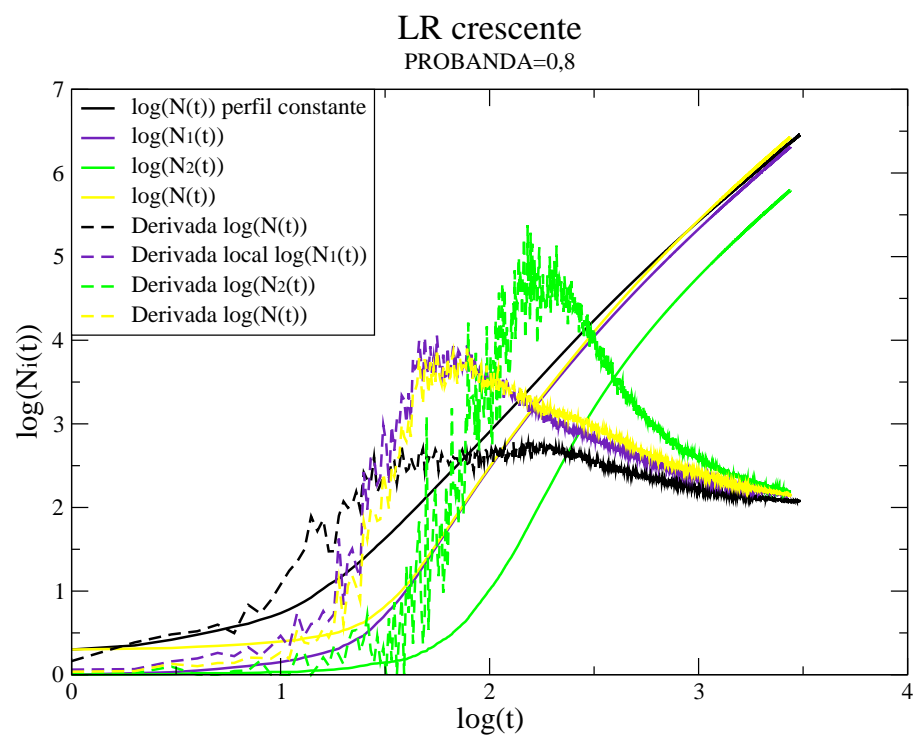

Figura 4.25: Gráficos de $\log (N(t)), \log \left(N_{1}(t)\right)$ e $\log \left(N_{2}(t)\right)$ como função de $\log (t)$ e suas respectivas derivadas locais para PROBANDA $=0,8$ e Limiar de Reprodução crescente. No modelo completo, $\mathrm{PROBDIF}=0,5$. O gráfico do perfil constante para $P R O B A N D A=0,8$ foi incluído para facilitar a comparação dos resultados. 


\begin{tabular}{l|c|c|c}
\hline \hline Medidas & $L R_{\text {decres }}(\mathbf{0 , 2})$ & $L R_{\text {decres }}(\mathbf{0 , 5})$ & $L R_{\text {decres }}(\mathbf{0 , 8})$ \\
\hline \hline$N f$ & $2,88\left(^{*}\right) \pm 0,02\left(^{*}\right)$ & $2,86\left(^{*}\right) \pm 0,02\left(^{*}\right)$ & $2,8\left(^{*}\right) \pm 0,5\left(^{*}\right)$ \\
$N f_{1}$ & $2,88\left(^{*}\right) \pm 0,02\left(^{*}\right)$ & $2,86\left(^{*}\right) \pm 0,02\left(^{*}\right)$ & $\left.2,1^{*}\right) \pm 0,3\left(^{*}\right)$ \\
$N f_{2}$ & $17 \pm 22$ & $164 \pm 195$ & $7\left(^{* *}\right) \pm 2\left(^{* *}\right)$ \\
$D M A X_{N}$ & - & - & - \\
$D M A X_{N 1}$ & - & - & - \\
$D M A X_{N 2}$ & $(0,8 ; 1,2)$ & $(1,4 ; 1,8)$ & $(2,2 ; 3,0)$ \\
$\eta$ & $2,030 \pm 0,004$ & $2,027 \pm 0,006$ & $2,061 \pm 0,008$ \\
$\eta_{1}$ & $2,030 \pm 0,004$ & $2,027 \pm 0,006$ & $2,058 \pm 0,009$ \\
$\eta_{2}$ & 0 & 0 & $2,07 \pm 0,01$ \\
\hline \hline
\end{tabular}

Tabela 3: Tabela com as propriedades estudadas nas simulações com a função $L R_{\text {decres }}$, para PROBANDA $=0,2,0,5$ e $0,8 .\left(^{*}\right) \times 10^{6}(* *) \times 10^{5}$

\begin{tabular}{l|c|c|c}
\hline \hline Medidas & LR crese $(\mathbf{0 , 2})$ & $L R_{\text {cresc }}(\mathbf{0 , 5})$ & $L R_{\text {cresc }} \mathbf{( 0 , 8 )}$ \\
\hline \hline$N f$ & $3,13\left(^{*}\right) \pm 0,04\left(^{*}\right)$ & $3,08\left(^{*}\right) \pm 0,05\left(^{*}\right)$ & $2,7\left(^{*}\right) \pm 0,4\left(^{*}\right)$ \\
$N f_{1}$ & $3,13\left(^{*}\right) \pm 0,04\left(^{*}\right)$ & $3,08\left(^{*}\right) \pm 0,05\left(^{*}\right)$ & $2,1\left(^{*}\right) \pm 0,3\left(^{*}\right)$ \\
$N f_{2}$ & $16 \pm 17$ & $97 \pm 116$ & $6\left(^{* *}\right) \pm 2\left(^{* *}\right)$ \\
$D M A X_{N}$ & $(1,1 ; 3,8)$ & $(1,4 ; 3,6)$ & $(1,8 ; 3,8)$ \\
$D M A X_{N 1}$ & $(1,1 ; 3,9)$ & $(1,3 ; 3,7)$ & $(1,8 ; 3,8)$ \\
$D M A X_{N 2}$ & $(1,1 ; 1,9)$ & $(1,4 ; 2,4)$ & $(2,2 ; 4,9)$ \\
$\eta$ & $2,040 \pm 0,003$ & $2,040 \pm 0,003$ & $2,157 \pm 0,006$ \\
$\eta_{1}$ & $2,040 \pm 0,002$ & $2,040 \pm 0,003$ & $2,146 \pm 0,007$ \\
$\eta_{2}$ & 0 & 0 & $2,193 \pm 0,009$ \\
\hline \hline
\end{tabular}

Tabela 4: Tabela com as propriedades estudadas nas simulações com a função

$$
L R_{\text {cresc }} \text {, para PROBANDA }=0,2,0,5 \text { e } 0,8 .\left(^{*}\right) \times 10^{6}(* *) \times 10^{5}
$$

A figura 4.26 mostra o número final médio de células no tumor $\left(N f, N f_{1}\right)$ como função do parâmetro PROBANDA. Uma vez que $N=N_{1}+N_{2}$, torna-se redundante o gráfico de $N_{2}$. Em todos os casos estudados, $N \sim N_{1}$ para PROBANDA $\lesssim 0,5^{3}$. Isso implica afirmar que o número final de células tipo 2 nos tumores é insignificante nesses casos, o que é confirmado pelas medidas de $N f_{2}$. Nota-

\footnotetext{
${ }^{3} \mathrm{Na}$ verdade observou-se que $N \sim N_{1}$ para PROBANDA $=0,2$ e 0,5 . Além de argumentos de continuidade, a discussão apresentada a seguir, permite afirmar que o comportamento deve ser o mesmo para qualquer valor de PROBANDA $\lesssim 0,5$.
} 
se que os desvios padrões para $N_{2}$ são maiores que o próprio valor médio, pois em algumas simulações $N f_{2}$ é muito maior que a média. Entretanto, para PROBANDA $=0,8$, em todos os casos estudados, $N f \neq N f_{1}$, indicando a presença de um número significativo de células tipo 2 .

Na figura 4.27, mostra-se a dependência de $\eta$ com PROBANDA, para cada um dos limiares de reprodução estudados. Da mesma forma, o coeficiente $\eta$ não se altera para os valores de PROBANDA $\lesssim 0,5$, independente do limiar de reprodução empregado. Para PROBANDA $=0,8$, verifica-se um aumento de $\eta$, mostrando que o maior número de células tipo 2 nos tumores, de fato, altera o seu regime de crescimento, de forma independente da função limiar de reprodução empregada.

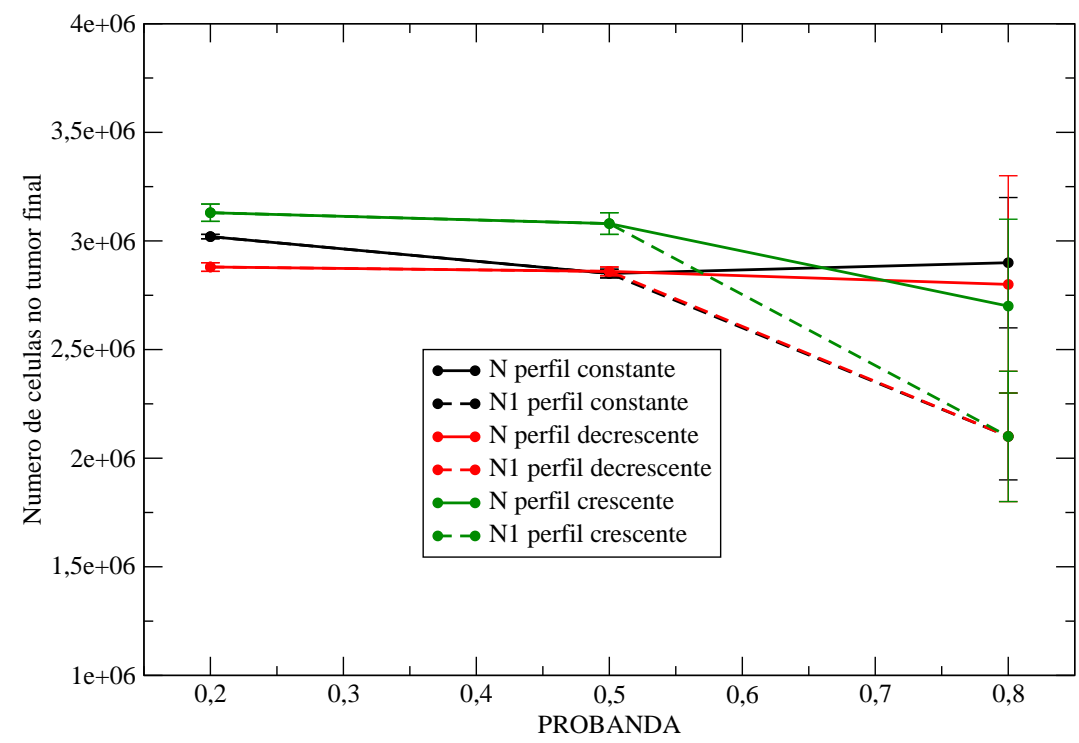

Figura 4.26: Número final de células, $N f$ e $N f_{1}$, no tumor em função de PROBANDA.

De forma análoga ao procedimento adotado nos modelos nulos, 


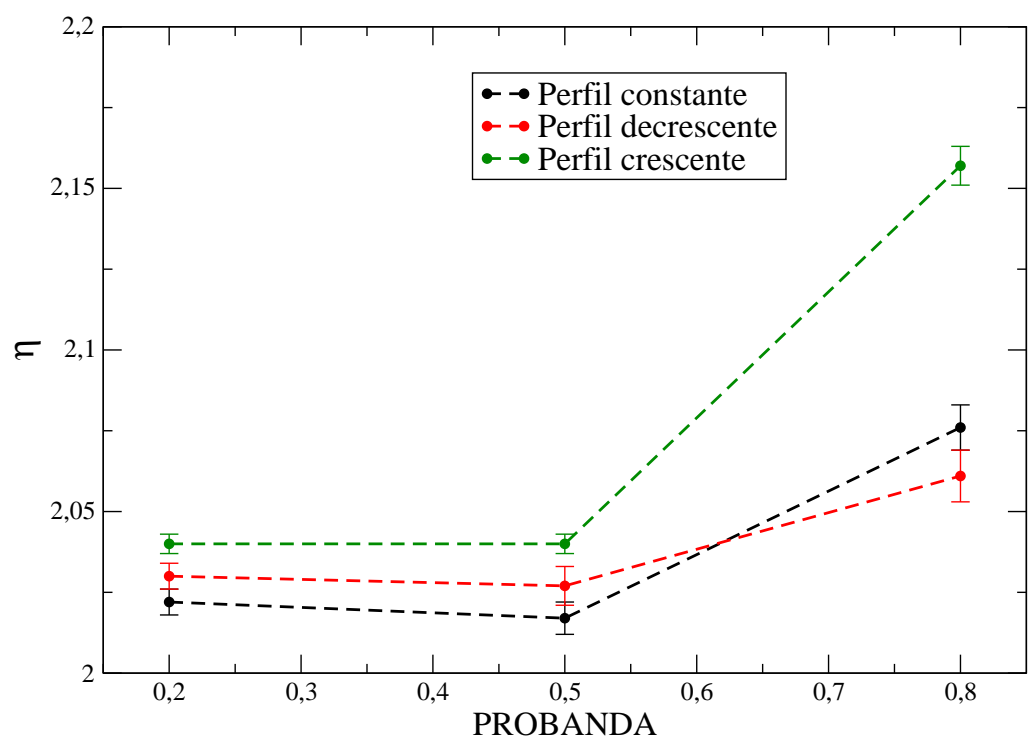

Figura 4.27: $\eta$ em função do parâmetro PROBANDA. Observa-se que há uma mudança no regime de crescimento do tumor para PROBANDA $\gtrsim 0,5$.

analisou-se qualitativamente o efeito da difusão com a morfologia do tumor antes, durante e após a região do ponto máximo da derivada local da curva $\log \left(N_{2}\right) \times \log (t)$ nos três perfis, visto que em todos os perfis, para todos os valores de PROBANDA, observa-se um ponto de inflexão. Essas imagens são vistas nas figuras 4.28 a 4.36 .

Nos casos $L R_{\text {const }}$ e $L R_{\text {cresc }}$, os tumores são mais compactos em torno do ponto de inflexão que no caso do $L R_{\text {decres }}$. Como esperado, essa função $\left(L R_{\text {decres }}\right)$ favorece o crescimento das células nas bordas, o que gera formas mais irregulares.

As simulações do modelo para os diferentes valores de PROBANDA revelam ainda uma importante carasterística do modelo, presente qualquer que seja a função LR empregada. As figuras 4.17 a 4.25 mostram que, a depender do valor de PROBANDA, o número de células do tipo 2 fica constante no regime estacionário. Imagens do 


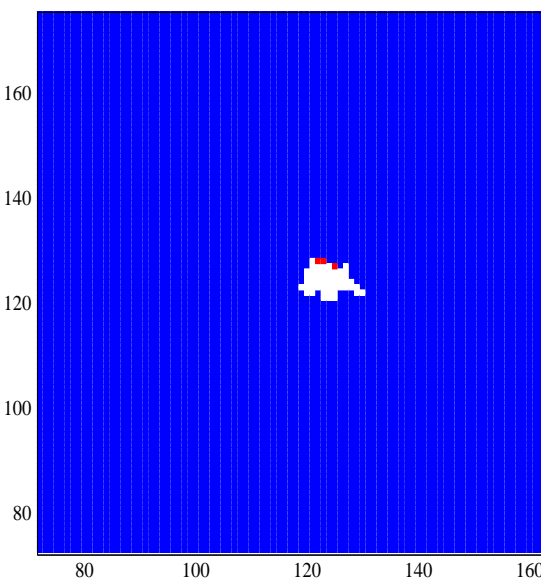

(a) $t=10$

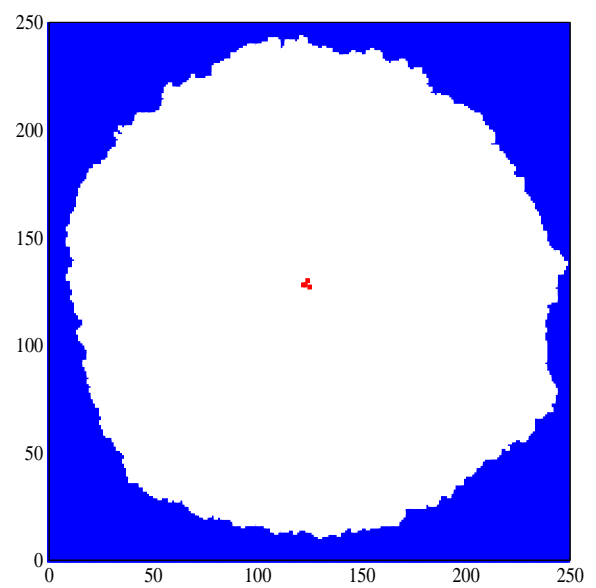

(b) Ao tocar a borda

Figura 4.28: Imagem do tumor (a) na região do ponto de inflexão $(\mathrm{t}=10)$ e (b) ao tocar a borda da rede para o caso $L R_{\text {constante }}(\mathbf{0 , 2 )} . \mathrm{MIN}=\mathrm{MAX}=0,5$ $\mathrm{PROBDIF}=0,5$ e PROBANDA $=0,2$.

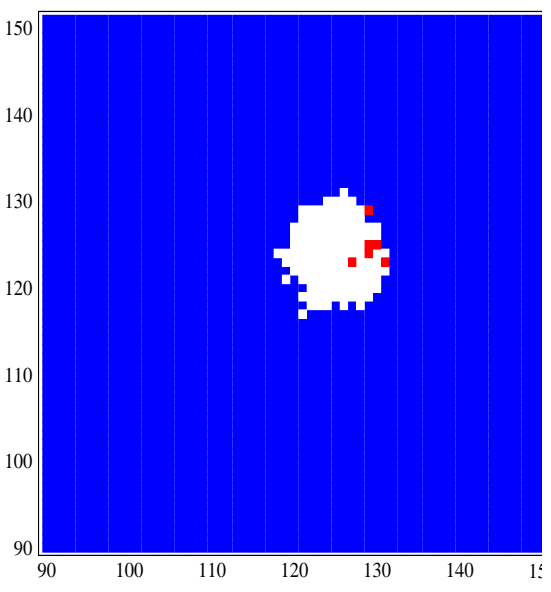

(a) $\mathrm{t}=20$

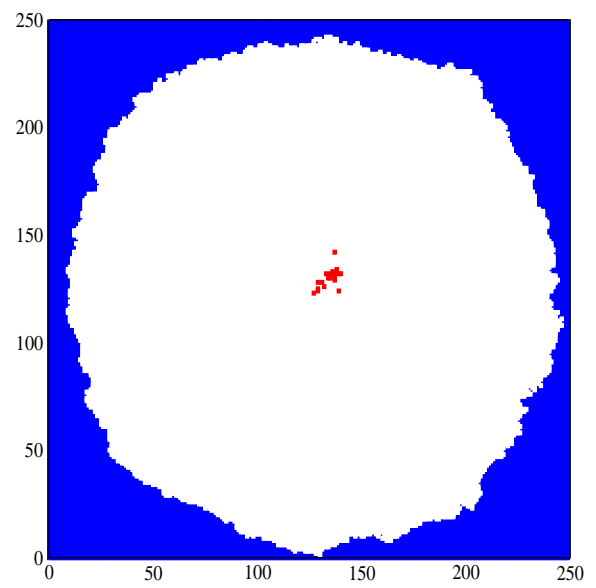

(b) Ao tocar a borda

Figura 4.29: Imagem do tumor (a) na região do ponto de inflexão $(t=20)$ e (b) ao tocar a borda da rede para o caso $L R_{\text {constante }}(\mathbf{0 , 5}) . \mathrm{MIN}=\mathrm{MAX}=0,5$ $\mathrm{PROBDIF}=0,5$ e PROBANDA $=0,5$. 


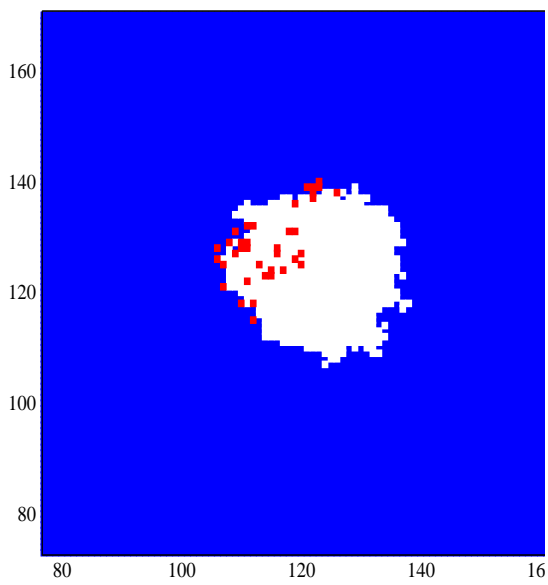

(a) $\mathrm{t}=10$

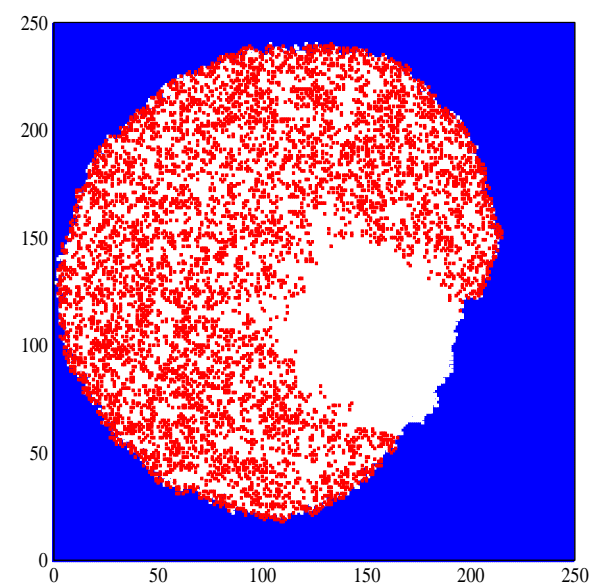

(b) Ao tocar a borda

Figura 4.30: Imagem do tumor (a) na região do ponto de inflexão $(\mathrm{t}=100)$ e $(\mathrm{b})$ ao tocar a borda da rede para o caso $L R_{\text {constante }}(\mathbf{0 , 8}) . \mathrm{MIN}=\mathrm{MAX}=0,5$ PROBDIF $=0,5$ e PROBANDA $=0,8$.

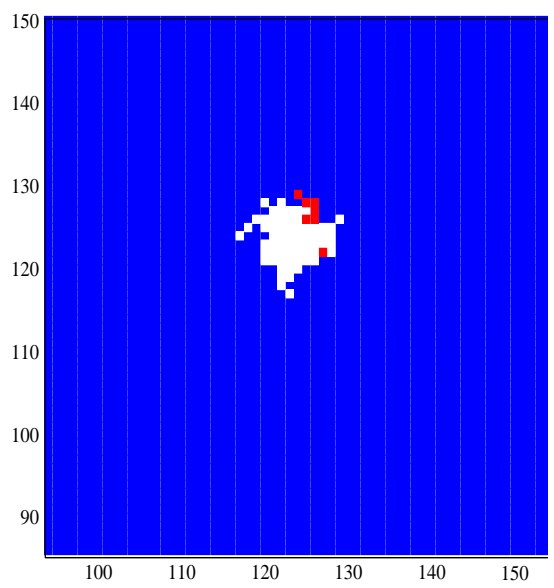

(a) $\mathrm{t}=10$

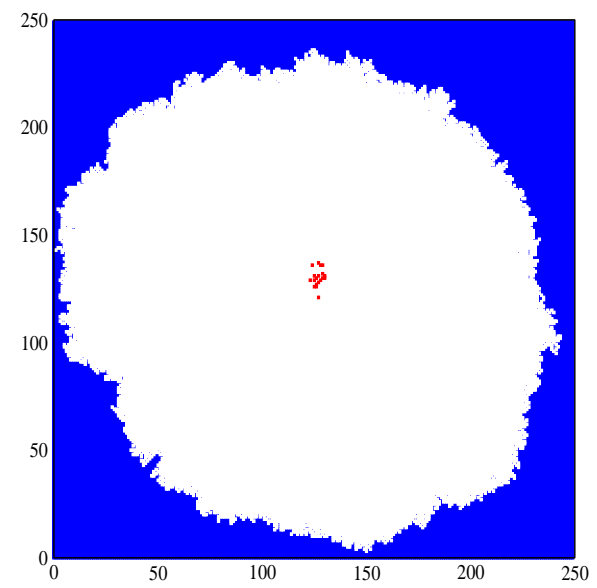

(b) Ao tocar a borda

Figura 4.31: Imagem do tumor (a) na região do ponto de inflexão $(\mathrm{t}=10)$ e (b) ao tocar a borda da rede para o caso $L R_{\text {decres }}(\mathbf{0 , 2}) \cdot \mathrm{MIN}=0,9 \mathrm{MAX}=0,1$ $\mathrm{PROBDIF}=0,5$ e PROBANDA $=0,2$. 


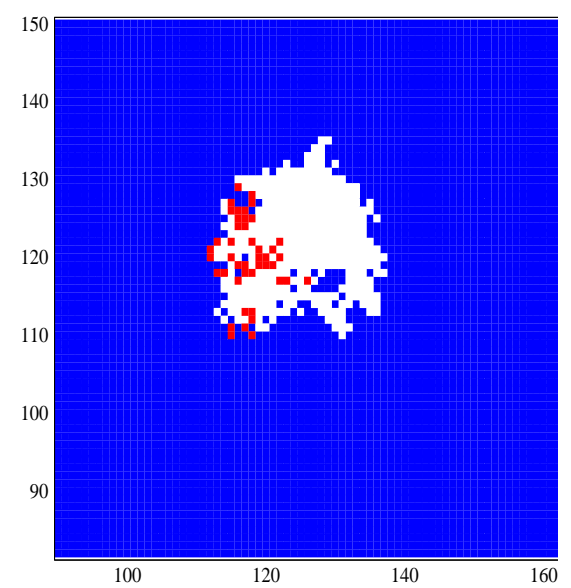

(a) $t=32$

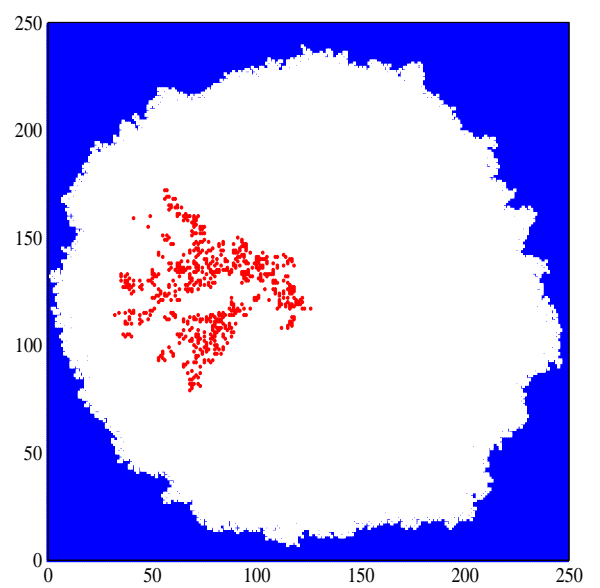

(b) Ao tocar a borda

Figura 4.32: Imagem do tumor (a) na região do ponto de inflexão $(t=10)$ e (b) ao tocar a borda da rede para o caso $L R_{\text {decres }}(\mathbf{0 , 5}) . \mathrm{MIN}=0,9 \mathrm{MAX}=0,1$ $\operatorname{PROBDIF}=0,5$ e PROBANDA $=0,5$.

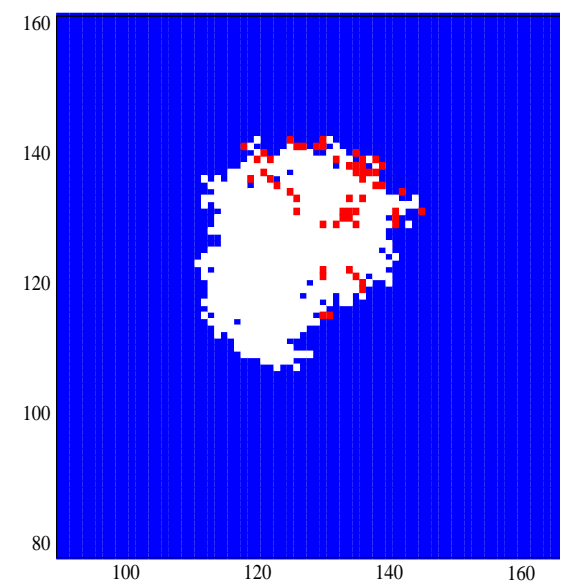

(a) $t=100$

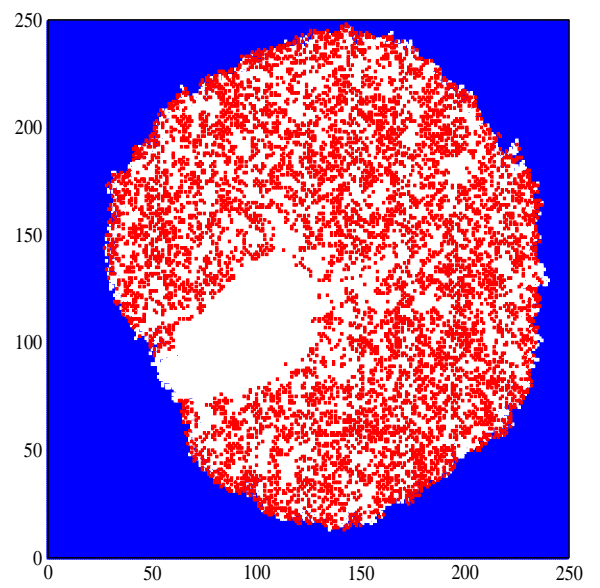

(b) Ao tocar a borda

Figura 4.33: Imagem do tumor (a) na região do ponto de inflexão $(\mathrm{t}=100)$ e $(\mathrm{b})$ ao tocar a borda da rede para o caso $L R_{\text {decres }}(\mathbf{0 , 8 )} . \mathrm{MIN}=0,9 \mathrm{MAX}=0,1$ $\mathrm{PROBDIF}=0,5$ e PROBANDA $=0,8$. 


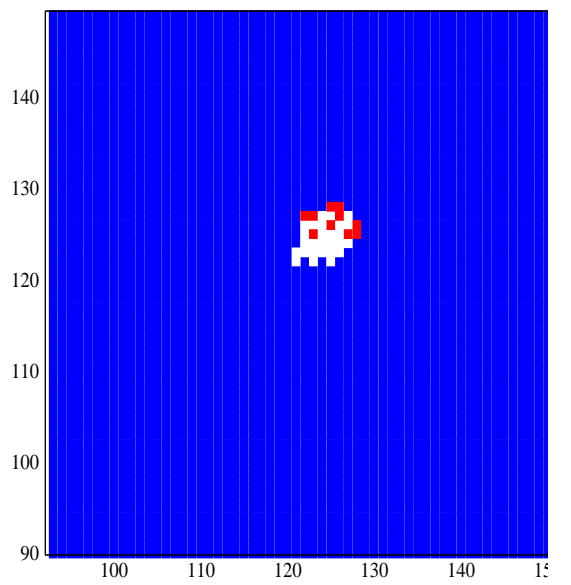

(a) $\mathrm{t}=10$

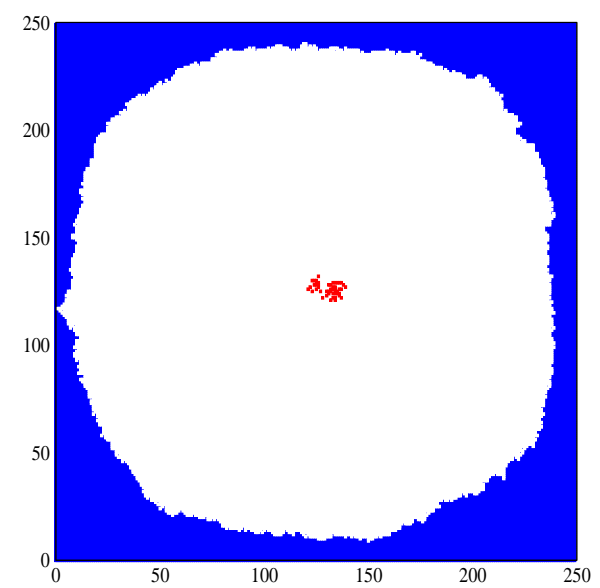

(b) Ao tocar a borda

Figura 4.34: Imagem do tumor (a) na região do ponto de inflexão $(\mathrm{t}=10)$ e $(\mathrm{b})$ ao tocar a borda da rede para o caso $L R_{\text {cres }}(\mathbf{0 , 2 )} . \quad \mathrm{MIN}=0,1 \quad \mathrm{MAX}=0,9$ $\mathrm{PROBDIF}=0,5$ e PROBANDA $=0,2$.

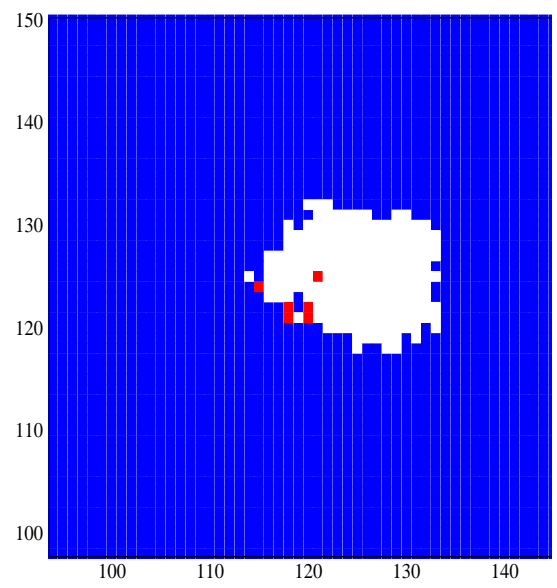

(a) $t=32$

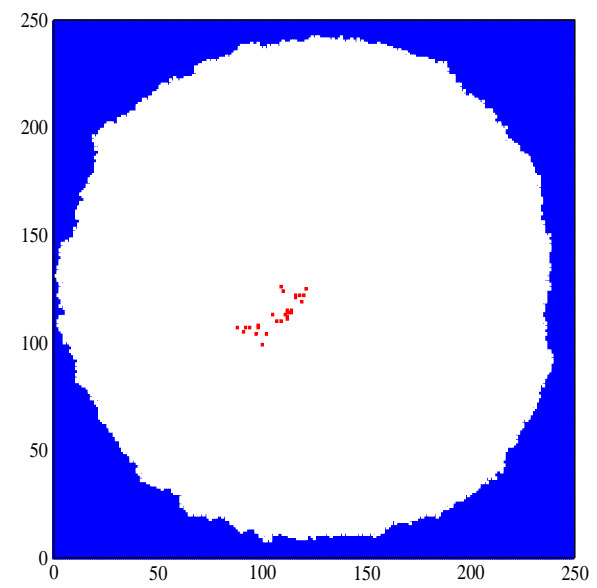

(b) Ao tocar a borda

Figura 4.35: Imagem do tumor (a) na região do ponto de inflexão ( $\mathrm{t}=32)$ e (b) ao tocar a borda da rede para o caso $L R_{\text {cres }}(\mathbf{0 , 5 )} . \mathrm{MIN}=0,1 \mathrm{MAX}=0,9$ PROBDIF $=0,5$ e PROBANDA $=0,5$. 


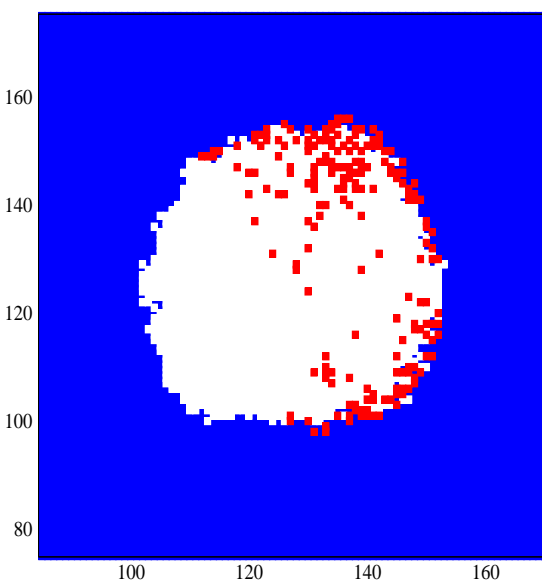

(a) $\mathrm{t}=160$

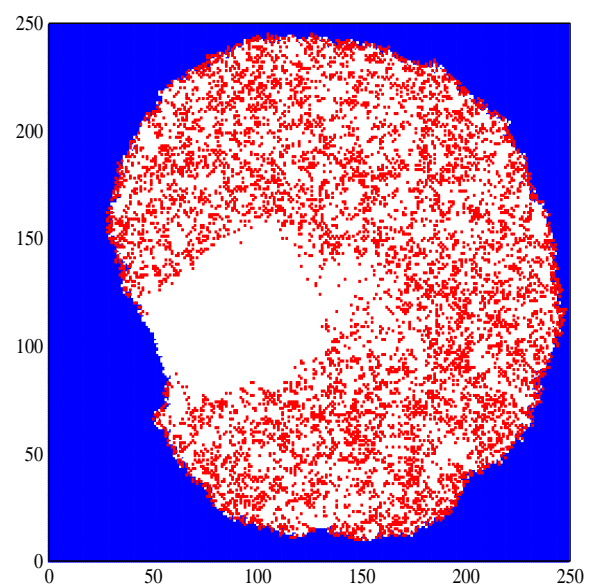

(b) Ao tocar a borda

Figura 4.36: Imagem do tumor (a) na região do ponto de inflexão $(\mathrm{t}=160)$ e (b) ao tocar a borda da rede para o caso $L R_{\text {cres }}(\mathbf{0 , 8 )} . \mathrm{MIN}=0,1 \mathrm{MAX}=0,9$ $\operatorname{PROBDIF}=0,5$ e PROBANDA $=0,8$.
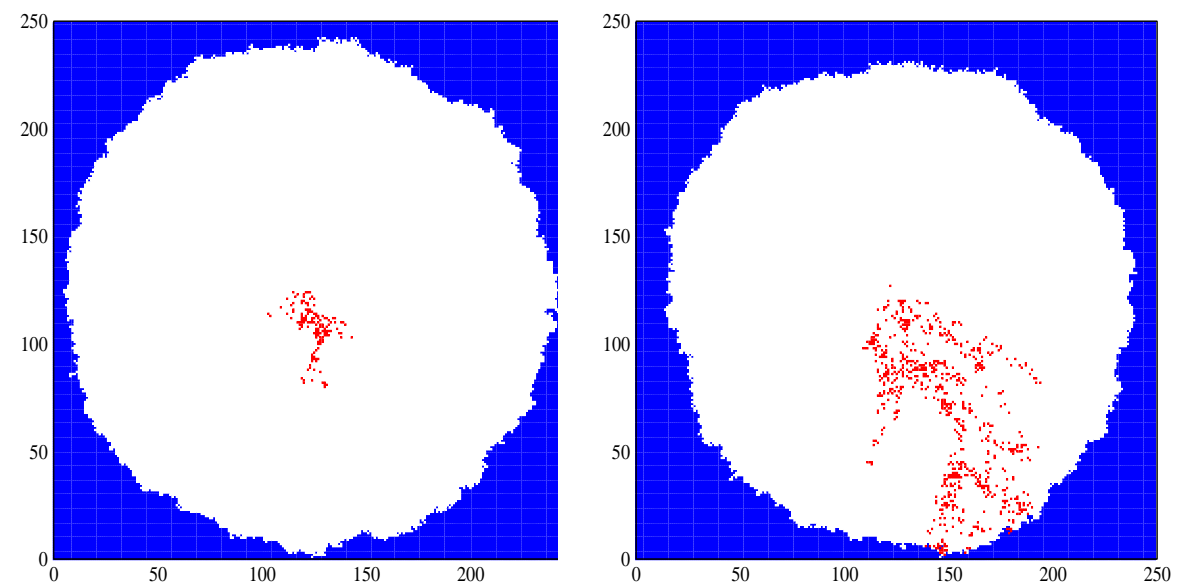

Figura 4.37: Valores dos parâmetros usados: $\mathrm{MIN}=\mathrm{MAX}=0,5 ; \mathrm{PROBDIF}=0,5$ e $\mathrm{PROBANDA}=0,51$ e 0,52 respectivamente. 

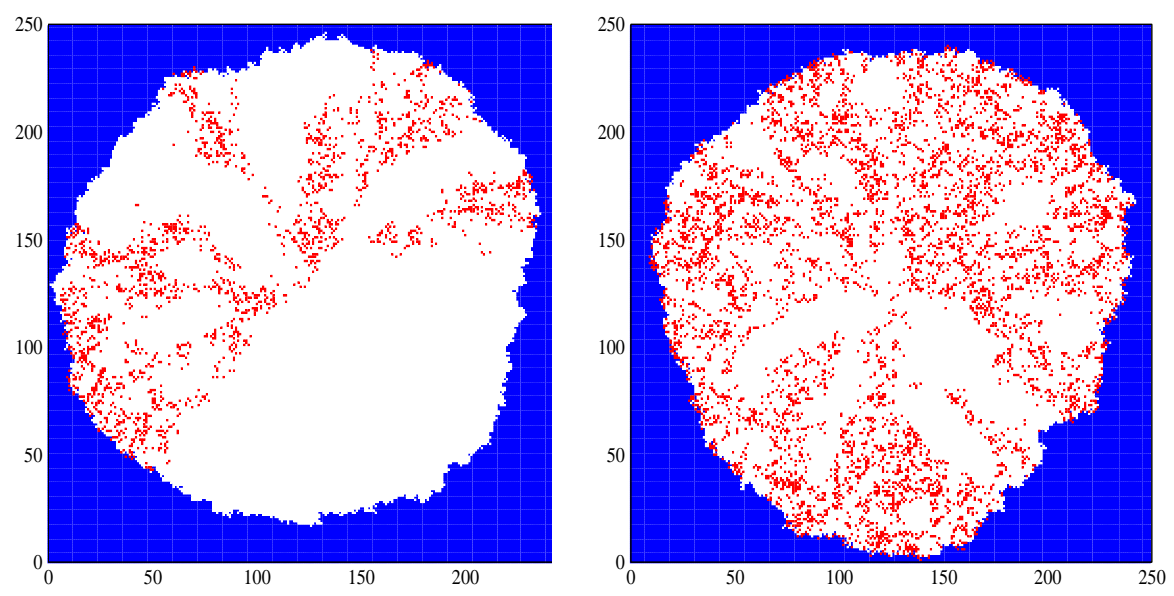

Figura 4.38: Valores dos parâmetros usados: $\mathrm{MIN}=\mathrm{MAX}=0,5 ; \mathrm{PROBDIF}=0,5$ e PROBANDA $=0,55$ e 0,6 respectivamente.

tumor final para algumas sementes, no caso $L R_{\text {constante, numa rede }}$ $250 \times 250$, mostram que, nesses casos, as células tipo 2 ficam aprisionadas dentro do tumor. Como essas células não tem mais espaço a sua volta para crescer, sua multiplicação é interrompida. À medida que se aumenta o valor de PROBANDA, o número de células tipo 2 aumenta e elas continuam se multiplicando por tempos cada vez mais longos. A partir de um certo valor, no entanto, sempre observa-se células tipo 2 na borda do tumor. As figuras 4.37 e 4.38 ilustram esse fato para quatro valores de PROBANDA $(0,51 ; 0,52$; $0,55$ e 0,6$)$. Verifica-se que, além do número de células do tipo 2 aumentar com o aumento de sua motilidade, elas se distribuem de forma cada vez mais homogênea no tumor.

Essa característica do modelo representa algo de grande interesse biológico, visto que, para certos valores de PROBANDA, as células tipo 2 sempre "escapam" para borda do tumor onde tem chance de desprender-se da massa tumoral e provocar uma metástase. Investigou-se melhor, portanto, essa importante característica.

Apesar de possuirem a mesma taxa de reprodução, devido à ca- 
pacidade de diferenciação, as células tipo 2 crescem mais lentamente. Dessa maneira, eventualmente, ficam "aprisionadas" no interior do mesmo. No entanto a sua motilidade, se suficientemente alta, é capaz de compensar esse fato. As figuras 4.39, 4.41 e 4.43 mostram a evolução no tempo do número de células tipo 2 , ou seja, $N_{2}(t)$, para vários valores de PROBANDA, para as três funções LR estudadas. As figuras 4.40, 4.42 e 4.44 mostram as derivadas locais dessas curvas.

Pode-se ver que existe um valor crítico de PROBANDA (PROBANDA $_{\text {critico }}$ ) a partir do qual o número de células tipo 2 está sempre crescendo, o que significa que estas sempre são encontradas na superfície do tumor, indicando uma mudança qualitativa no desenvolvimento deste. $\mathrm{O}$ valor de $\mathrm{PROBANDA}_{\text {critico }}$ é diferente para cada função LR e pode ser estimado através dos gráficos de $N_{2}(t)$ e suas derivadas locais. Obteve-se, quando a função $L R_{\text {constante }}$ é empregada, PROBANDA ${ }_{\text {critico }} \sim 0,53$; quando $L R_{\text {decres }}$ é empregada, PROBANDA critico $_{2} \sim 0,6$ e quando $L R_{\text {cresc }}$ é empregada, $\mathrm{PROBANDA}_{\text {critico }} \sim 0,58$.

Nos casos em que PROBANDA é menor que o valor crítico, o número de células do tipo tipo 2 na maioria das simulações tornase constante para tempos longos. Dir-se-á que o número de células tipo 2 " congelou " nessas simulações. À medida que PROBANDA se aproxima do valor crítico, parte das simulações deixa de "congelar". A partir de certo ponto, nenhuma simulação mais "congela".

Pode-se concluir, a partir disso, que a dinâmica de crescimento apresenta duas fases: uma fase dita metastática e uma fase não metastática. Estas fases caracterizariam o potencial metastático do tumor. A fase não metastática representaria uma situação na qual o risco de metástase seria nulo, já que para a ocorrência desse 
fenômeno é preciso que alguma célula tumorizada escape do tumor original e alcance um vaso sanguíneo.

A mobilidade das células é um fator preponderante para a ocorrên cia de metástase no organismo. Apesar do modelo implementado não contemplar o fenômeno da angiogênese, ele mostra como a mobilidade de células com características de células tronco, sabidamente mais móveis que outras células, poderia facilitar a metástase.

Perfil constante

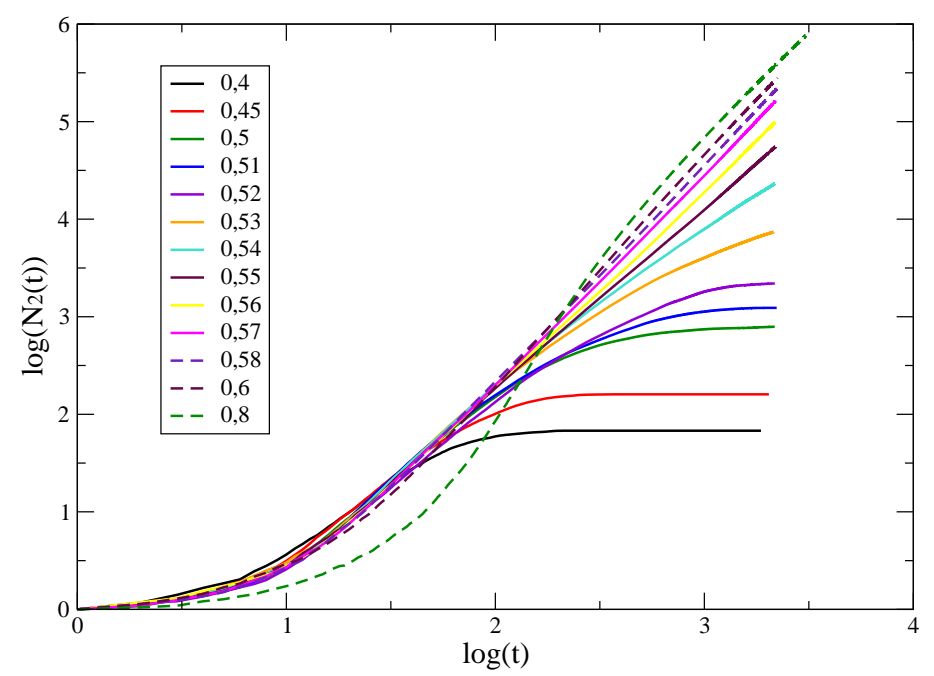

Figura 4.39: $\log \left(N_{2}\right) \times \log (t)$ para diferentes valores de PROBANDA, $L R_{\text {constante }}$ e PROBDIF $=0,5$. Através dessas curvas pode-se estimar $\mathrm{PROBANDA}_{\text {critico }} \sim 0,53$.

\subsubsection{Transição de fase metástase - não mestástase}

O conceito de transição de fase, introduzido no contexto de sistemas termodinâmicos em equilíbrio, tem sido hoje aplicado com sucesso no estudo de diversos sistemas fora do equilíbrio. Em particular, o estudo de transições de fase em modelos definidos em redes tem 


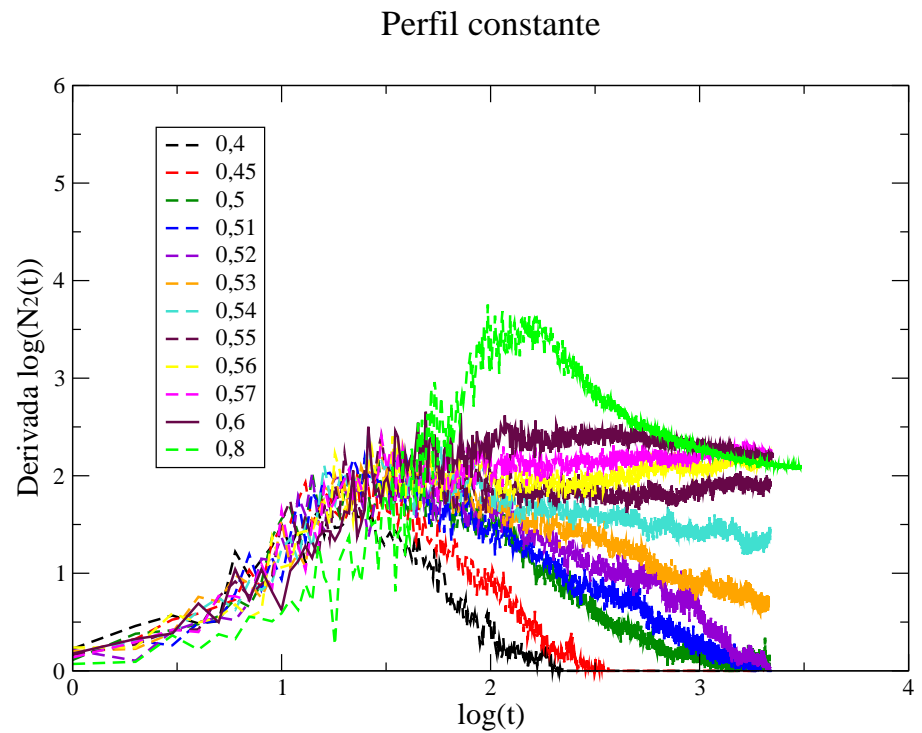

Figura 4.40: Derivada local das curvas da figura 4.39. Estima-se que o valor de PROBANDA a partir do qual a derivada local deixa de ser nula é $\sim 0,53$.

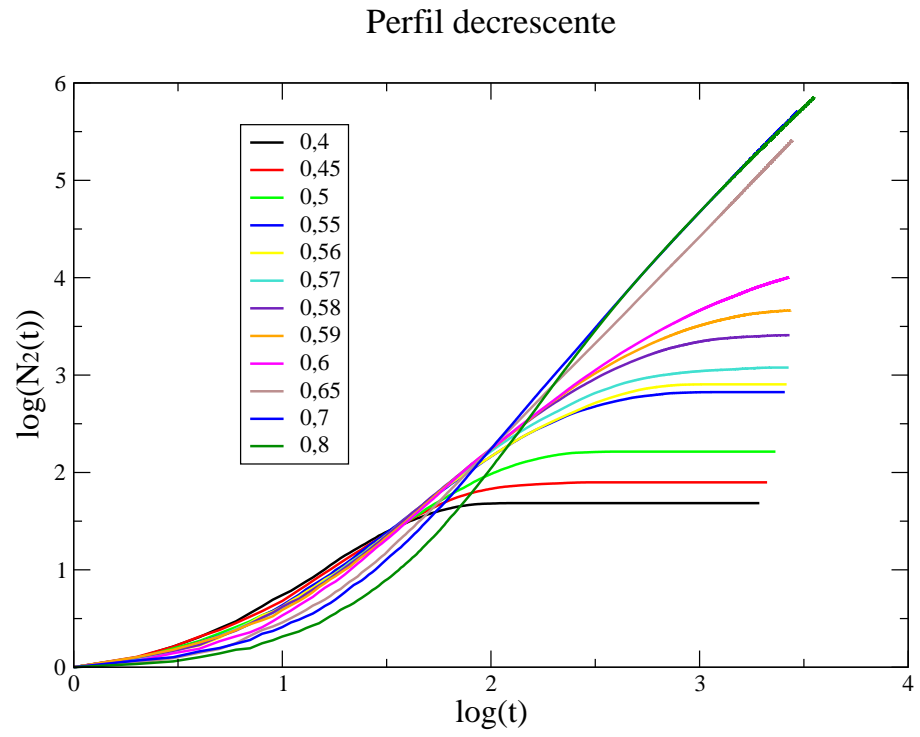

Figura 4.41: $\log \left(N_{2}\right) \times \log (t)$ para diferentes valores de PROBANDA, $L R_{\text {decresc }}$ e PROBDIF $=0,5$. Através dessas curvas pode-se estimar PROBANDA critico $_{\text {P }}$ 0,60 . 


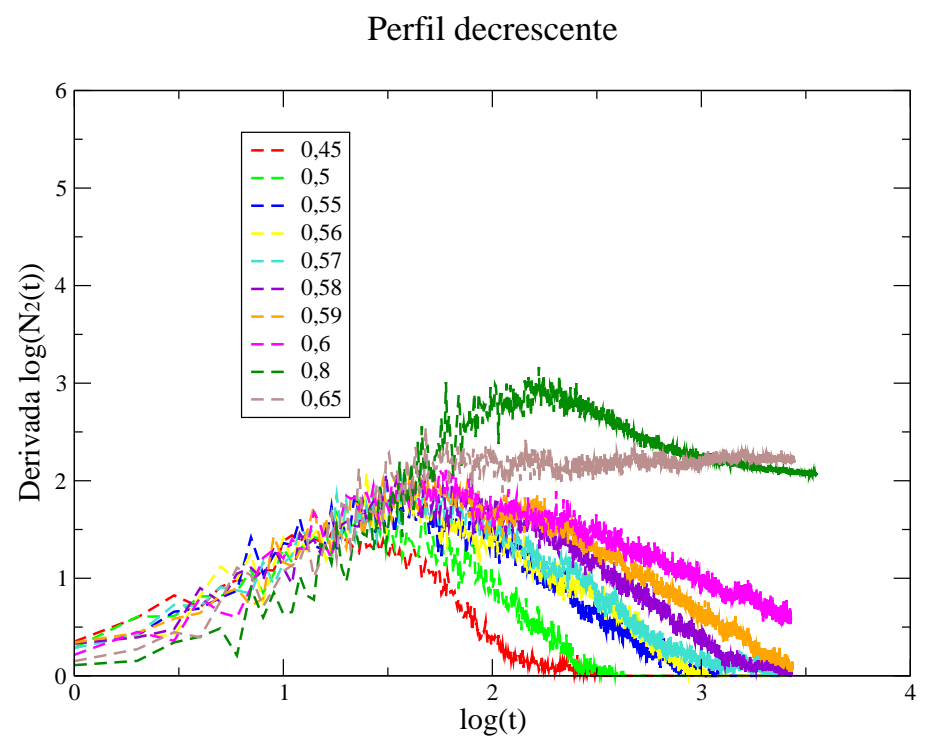

Figura 4.42: Derivada local das curvas da figura 4.41. Estima-se que o valor de PROBANDA a partir do qual a derivada local deixa de ser nula é $\sim 0,6$.

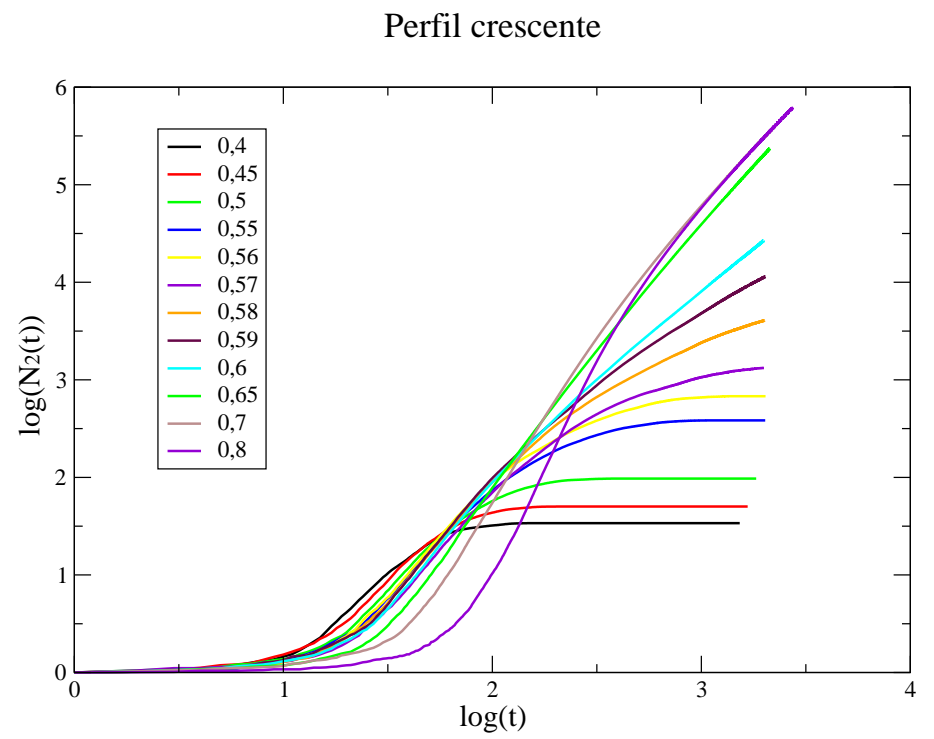

Figura 4.43: $\log \left(N_{2}\right) \times \log (t)$ para diferentes valores de PROBANDA, $L R_{\text {cresc }}$ e PROBDIF $=0,5$. Através dessas curvas pode-se estimar PROBANDA critico $_{2} \sim$ 0,58 . 


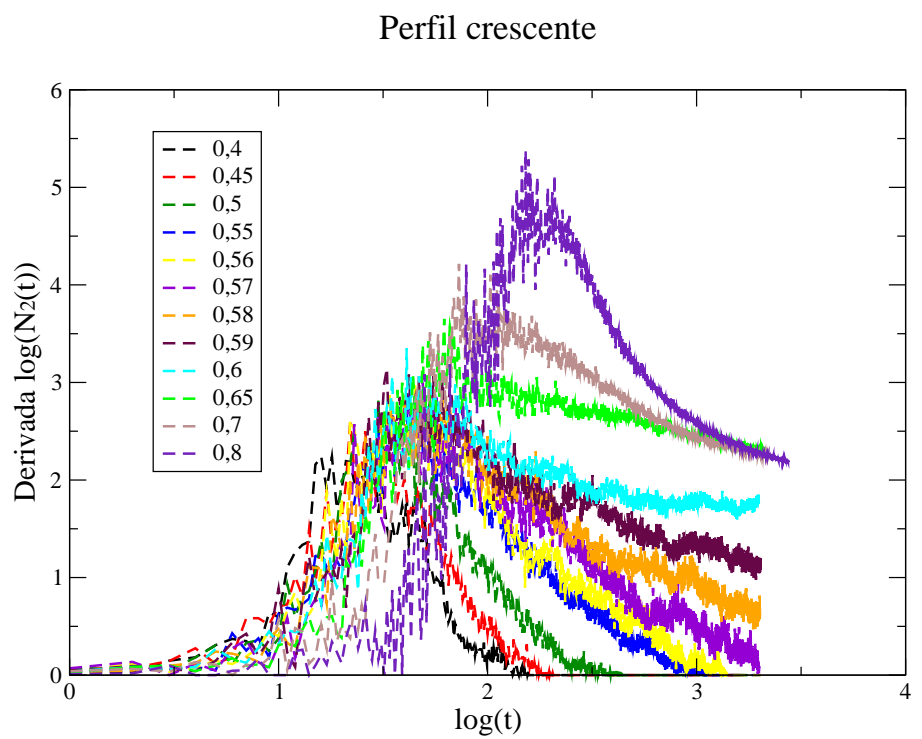

Figura 4.44: Derivada local das curvas da figura 4.43. Estima-se que o valor de PROBANDA a partir do qual a derivada local deixa de ser nula é $\sim 0,58$.

despertado enorme interesse [38, 39, 40], não só em sistemas físicos, mas em inúmeros problemas que podemos chamar de não físicos. Ao contrário do que ocorre com as transições de fase em sistemas em equilíbrio, não há ainda um formalismo bem estabelecido para lidar com transições de fase em sistemas fora do equilíbrio.

Um exemplo típico e extremamente geral (um número muito grande de modelos acaba apresentando exatamente a mesma transição, ou seja, pertencem à mesma classe de universalidade) é o problema conhecido como percolação [39, 40, 41], proposto inicialmente para estudar a propagação de fluidos em meios porosos. O que se observa é que há dois regimes, um no qual o fluido consegue se propagar através do meio poroso, e outro no qual a propagação se extingue. Um modelo para esse fenômeno consiste em considerar um reticulado no qual cada sítio é aleatoriamente ocupado com problabilidade $p$, e vazio com probabilidade $(1-p)$. Se $p$ é menor que um certo valor crítico $p_{c}$, observa-se um grande número de clusters de 
sítios vizinhos, em geral bem menores que o tamanho do reticulado, e completamente cercados por sítios vazios. Mas se $p>p_{c}$ sempre se observa o aparecimento de um cluster enorme, capaz de ligar dois lados opostos do reticulado, caracterizando uma transição de fase geométrica.

Nesse trabalho não houve tempo de estudar com cuidado a possível transição de fase observada. Mostrar-se-á, através de um estudo preliminar, que encontrou-se evidências de uma transição similar, pois verificou-se uma mudança repentina no comportamento macroscópico do tumor como função do parâmetro PROBANDA, que será assumido como parâmetro de controle. O que torna o estudo dessa transição tão atraente é a sua importante consequência biológica: a possibilidade da existência de um estado metastático. Conforme visto no capítulo 2, a metástase é o principal mecanismo do câncer que leva o organismo a óbito.

A fim de melhor caracterizar a possível transição de fase descoberta, definiu-se como parâmetro de ordem a fração de simulações em que o número de células tipo 2 ficava constante com o tempo, ou seja, "congelava". Nesses casos, a densidade de células tipo 2 sempre tenderia a zero quando o tamanho do sistema tendesse a infinito; ainda, definindo-se como células ativas as células que ainda podem se reproduzir, ou seja, ainda têm espaço vazio à sua volta, percebe-se que o "congelamento" das células tipo 2 significa que a sua atividade se extinguiu. Pode-se considerar que - em relação à atividade das células tipo 2 o sistema evoluiu para um estado absorvente.

Definiu-se como frequência de "congelamento" (Freq) o número de simulações, dentre as cem simulações efetuadas, em que o número de células tipo 2 torna-se constante. A tabela 5 mostra a frequência de "congelamento" para diferentes valores de PROBANDA para o 
caso $L R_{\text {constante }}$. Esses mesmos resultados estão também na figura 4.45. Próximo da transição calculou-se o desvio de Freq. Para calcular esse desvio, escolheu-se aleatoriamente, do conjunto de cem arquivos, cinco sub-conjuntos de vinte arquivos cada um. Calculouse Freq para cada um desses sub-conjuntos de vinte e o desvio considerado foi o desvio padrão dos cinco valores de Freq.

Na figura 4.45, observa-se que Freq exibe o comportamento típico de um parâmetro de ordem durante uma transição: Freq $=1$ se PROBANDA $<$ PROBANDA $_{\text {critico }}$ e Freq $=0$ se PROBANDA $>$ PROBANDA $_{\text {critico }}$ que, nesse caso, $\sim 0,53$. Como o tamanho da rede é finito, na prática, não se observa uma transição descontínua, que só seria observada no limite termodinâmico (sistema infinito). A figura 4.46 trás o comportamento de Freq $\times$ PROBANDA para diversos tamanhos de rede, mostrando que, de fato, a transição tornase mais descontínua à medida que a rede aumenta.

O mesmo estudo realizado para $L R_{\text {constante }}$ foi realizado para os outros perfis de reprodução, $L R_{\text {decres }}$ e $L R_{\text {cresc }}$. Os resultados estão na tabela 6 e na figura 4.47 e mostram que o mesmo comportamento é observado nos três casos estudados. O valor de PROBANDA critico, $_{\text {, }}$ no entanto, varia. O perfil $L R_{\text {constante, }}$ em que as células se reproduzem independente da sua vizinhança, é o perfil para o qual a transição para o estado metastático ocorre para o menor valor de PROBANDA. A transição é mais retardada quando a função $L R_{\text {decres }}$ é adotada.

Biologicamente, a existência de uma trasição desse tipo pode explicar porquê determinados tumores são mais agressivos que outros, e talvez até mesmo explicar diferenças fundamentais entre tumores benignos e malignos. Por exemplo, os tumores ditos benignos nunca provocam metastáse no organismo; no caso do câncer de pele, como 
visto no capítulo 2, os carcinomas são ditos não melanoma exatamente porque nunca metastizam.

\begin{tabular}{|c|c|}
\hline PROBANDA & Freq \\
\hline 0,2 & 1 \\
\hline 0,4 & 1 \\
\hline 0,45 & 1 \\
\hline 0,48 & 1 \\
\hline 0,5 & 1 \\
\hline 0,51 & 1 \\
\hline 0,52 & 0,99 \\
\hline 0,53 & $0,67 \pm 0,12$ \\
\hline 0,532 & $0,67 \pm 0,04$ \\
\hline 0,533 & $0,66 \pm 0,15$ \\
\hline 0,534 & $0,51 \pm 0,11$ \\
\hline 0,535 & $0,49 \pm 0,09$ \\
\hline 0,537 & $0,38 \pm 0,14$ \\
\hline 0,538 & $0,39 \pm 0,17$ \\
\hline 0,539 & $0.39 \pm 0.17$ \\
\hline 0,54 & $0,34 \pm 0,12$ \\
\hline 0,55 & $0,27 \pm 0,09$ \\
\hline 0,56 & $0,19 \pm 0,09$ \\
\hline 0,57 & $0,14 \pm 0,07$ \\
\hline 0,58 & $0,14 \pm 0,07$ \\
\hline 0,59 & $0,12 \pm 0,11$ \\
\hline 0,6 & $0,17 \pm 0,06$ \\
\hline 0,65 & 0,05 \\
\hline 0,7 & 0,05 \\
\hline 0,75 & 0,03 \\
\hline 0,8 & 0,02 \\
\hline 0,85 & 0,02 \\
\hline 0,9 & 0,00 \\
\hline 0,95 & 0,00 \\
\hline
\end{tabular}

Tabela 5: Frequências de "congelamento" (Freq) para diferentes valores de PROBANDA para o caso $L R_{\text {constante }}$ em uma rede $2000 \times 2000$. 
De acordo com o modelo proposto as células que originam os carcinomas (se células tronco tumorais) devem possuir uma baixa motilidade.

\section{Perfil constante}

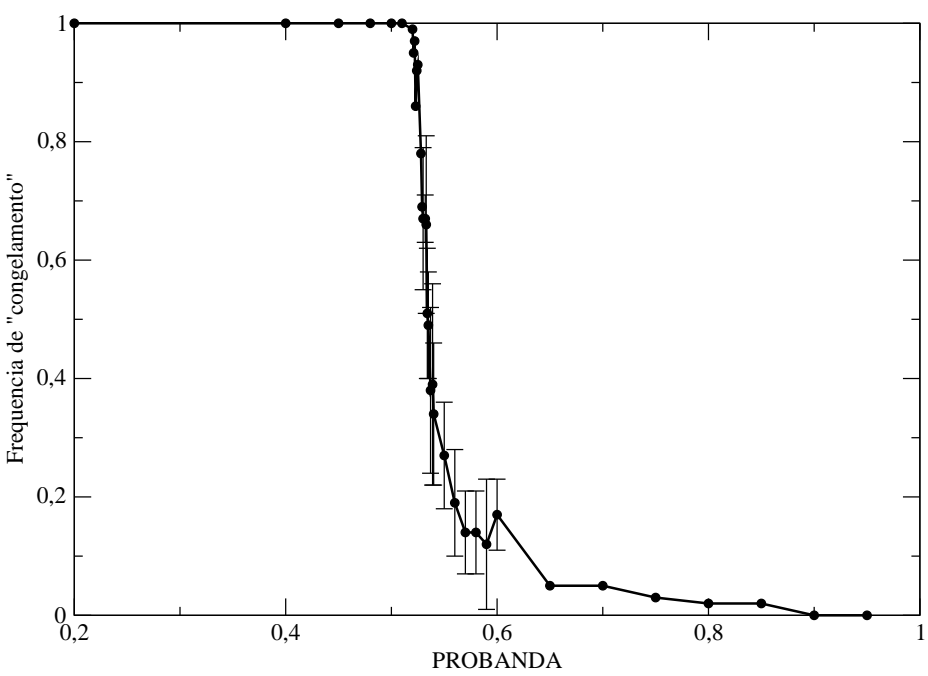

Figura 4.45: Freq como função de PROBANDA para $L R_{\text {constante }}$ em uma rede $2000 \times 2000$. Estima-se que a transição ocorra na vizinhança de 0,53.

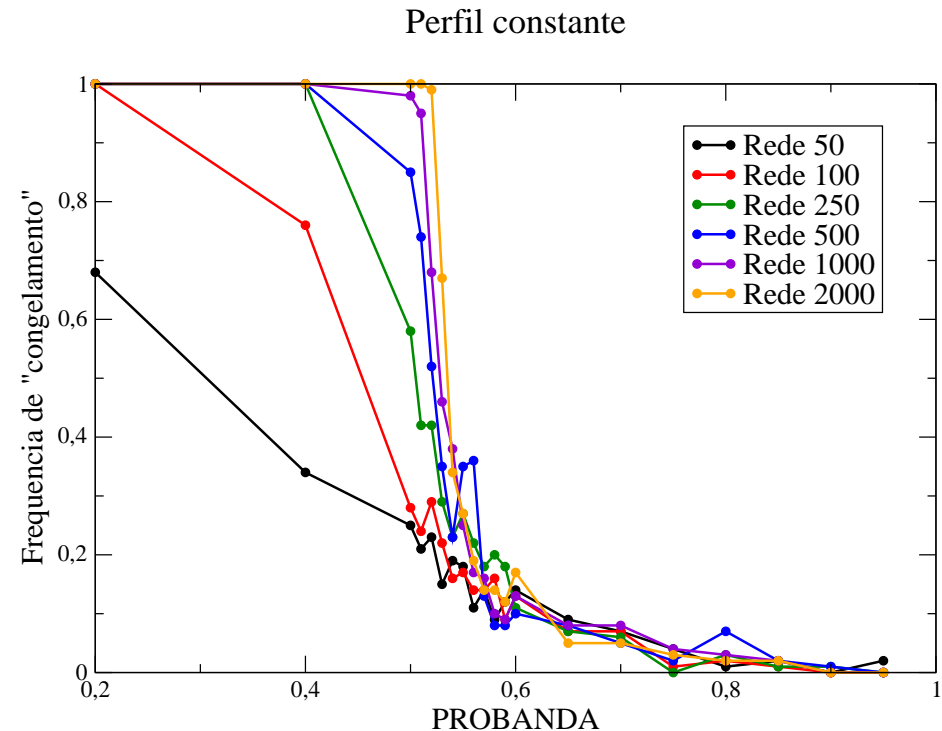

Figura 4.46: Freq como função de PROBANDA para $L R_{\text {constante }}$ para diversos tamanhos de rede. 


\begin{tabular}{l|c|c}
\hline \hline $\boldsymbol{P R O B A \boldsymbol { N } \boldsymbol { A }}$ & Freq $L R_{\text {decres }}$ & Freq $L R_{\text {cresc }}$ \\
\hline \hline 0,2 & 1 & 1 \\
0,4 & 1 & 1 \\
0,5 & 1 & 1 \\
0,51 & 1 & 1 \\
0,52 & 1 & 1 \\
0,53 & 1 & 1 \\
0,54 & 1 & 1 \\
0,55 & 1 & 1 \\
0,56 & 1 & 1 \\
0,57 & 0,99 & 0,98 \\
0,58 & 0,97 & 0,78 \\
0,59 & 0,68 & 0,48 \\
0,6 & 0,14 & 0,34 \\
0,65 & 0,08 & 0,13 \\
0,7 & 0,03 & 0,10 \\
0,75 & 0,07 & 0,08 \\
0,8 & 0,02 & 0,06 \\
0,85 & 0,00 & 0,02 \\
0,9 & 1 & 0,02 \\
0,95 & 1 & 0,00 \\
\hline \hline
\end{tabular}

Tabela 6: Frequências de "congelamento" (Freq) para diferentes valores de PROBANDA para os casos $L R_{\text {descres }}$ e $L R_{\text {cresc }}$ em redes $2000 \times 2000$.

A figura 4.48 mostra como o coeficiente $\eta$ varia com o PROBANDA. Verifica-se que, na fase não metastática, em todos os casos, $\eta \sim$ constante; também em todos os casos $\eta$ apresenta um mínimo que

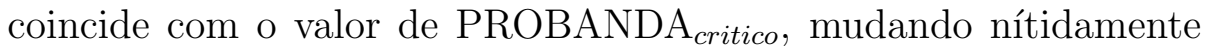
de comportamento quando PROBANDA $>$ PROBANDA $_{\text {critico }}$.

Em todas as simulações realizadas até agora a velocidade de reprodução dos dois tipos de célula foram as mesmas, ou seja, dada uma função LR os valores dos parâmetros MIN e MAX eram os mesmos. Entretanto, no modelo completo com $\mathrm{PROBDIF} \neq 0$, as 


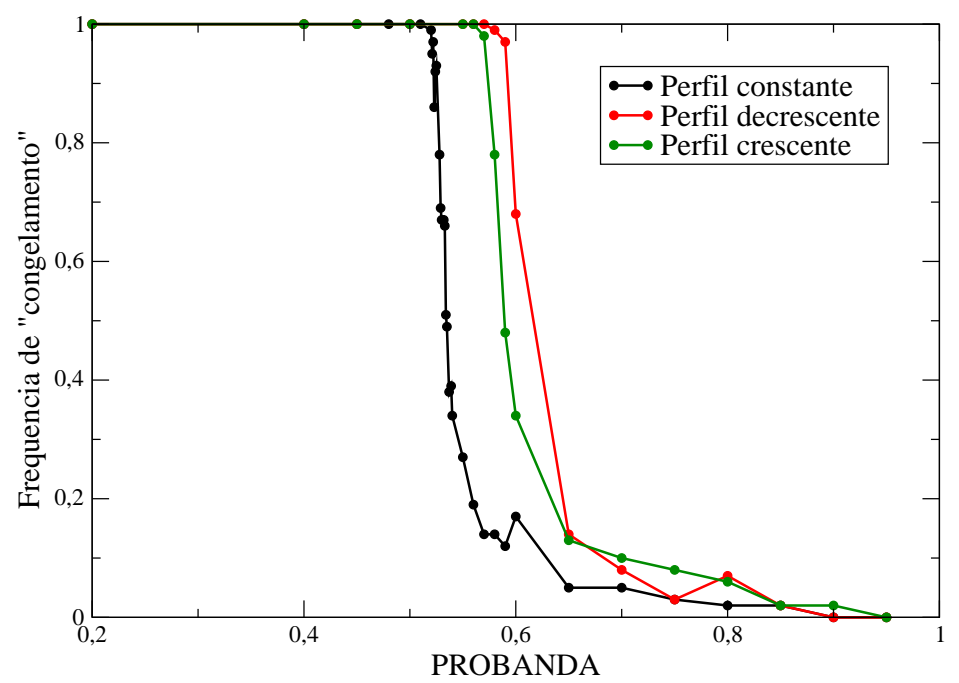

Figura 4.47: Freq como função de PROBANDA para $L R_{\text {constante }} L R_{\text {decres }}$, $L R_{\text {cres }}$. Estima-se que a transição ocorra na vizinhança de $0,53,0,6$ e 0,58 respectivamente.

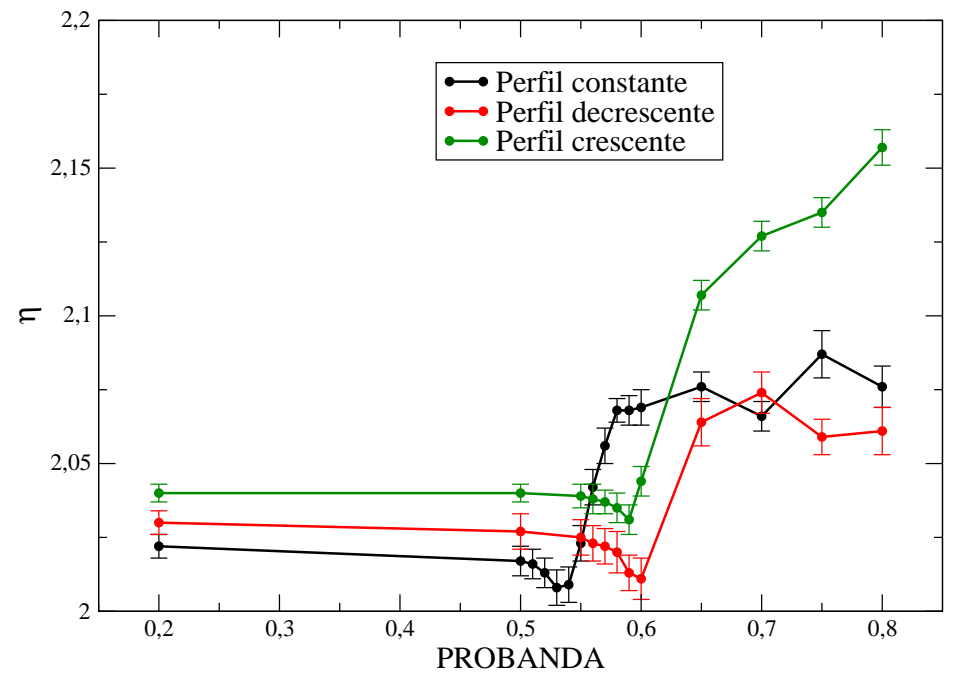

Figura 4.48: $\eta$ como função de PROBANDA para $L R_{\text {constante }}, L R_{\text {decres }}, L R_{\text {cres }}$. Observa-se que, em todos os casos, há um ponto de mínimo nas três curvas que coincide com o valor de $P R O B A N D A_{\text {critico. }}$ O gráfico evidencia uma mudança no regime de crescimento tumoral após a transição. 
células tipo 2 se reproduzem mais lentamente, como discutido no início deste capítulo, ao justificar-se o re-escalonamento do tempo apresentado na figura 4.9. Com o objetivo de investigar a influência da velocidade de reprodução na existência das fases metastática e não metastática e principalmente se, para uma velocidade suficientemente alta de reprodução das células tipo 2 a fase não metastática poderia desaparecer, realizou-se o estudo a seguir. Apenas a função $L R_{\text {constante }}$ foi considerada nessa etapa do trabalho, e definiu-se como $\alpha$ a razão entre as taxas de crescimento das células tipo 2 e tipo 1 :

$$
\alpha=\frac{M I N_{\text {tipo 2 }}}{M I N_{\text {tipo } 1}} .
$$

Como adotou-se a função $L R_{\text {constante, }} \mathrm{MIN}=\mathrm{MAX}$ sempre. Para células tipo 1 MIN1 foi mantido constante e igual à 0,5 , variando-se apenas MIN2. A tabela 8 mostra os valores de $\alpha$ para os diversos valores de MIN2 estudados. Como MIN2 não pode ser maior que um, para aumentar $\alpha$ ainda mais, deveria-se diminuir MIN1. Em princípio uma diminuição de MIN1 não deveria afetar o resultado qualitativamente, apenas aumentar o tempo necessário para que o tumor toque a borda (no modelo nulo 1 é isso que ocorre). Mas, como não se confirmou esse fato no modelo completo, a continuidade desse estudo foi deixada para depois.

A figura 4.49 trás os resultados obtidos para Freq como função de PROBANDA, para diversos valores de $\alpha$. Observa-se, como esperado, que o aumento da taxa de reprodução das células tipo 2 em relação ao das células tipo 1 influencia no valor de $P R O B A N D A_{\text {critico, }}$, que diminui. Não foi possível porém, sem mais simulações numéricas, verificar se, para algum valor de $\alpha$, a fase não-metastática desaparecia. Em todos os casos estudados, observa-se $100 \%$ de simulações 
nas quais células tipo 2 "congelam" se PROBANDA $\lesssim 0,2^{4}$.

\begin{tabular}{c|c}
\hline \hline$\alpha$ & $M I N 2=M A X 2$ \\
\hline \hline 0,6 & 0,3 \\
0,8 & 0,4 \\
1,0 & 0,5 \\
1,1 & 0,55 \\
1,3 & 0,65 \\
1,5 & 0,75 \\
1,7 & 0,85 \\
2,0 & 1,00 \\
\hline \hline
\end{tabular}

Tabela 8: Valores de $\alpha$ para os diferentes MIN2 estudados. Em todos os casos MIN1=MAX1 foi mantido constante e igual à 0,5 .

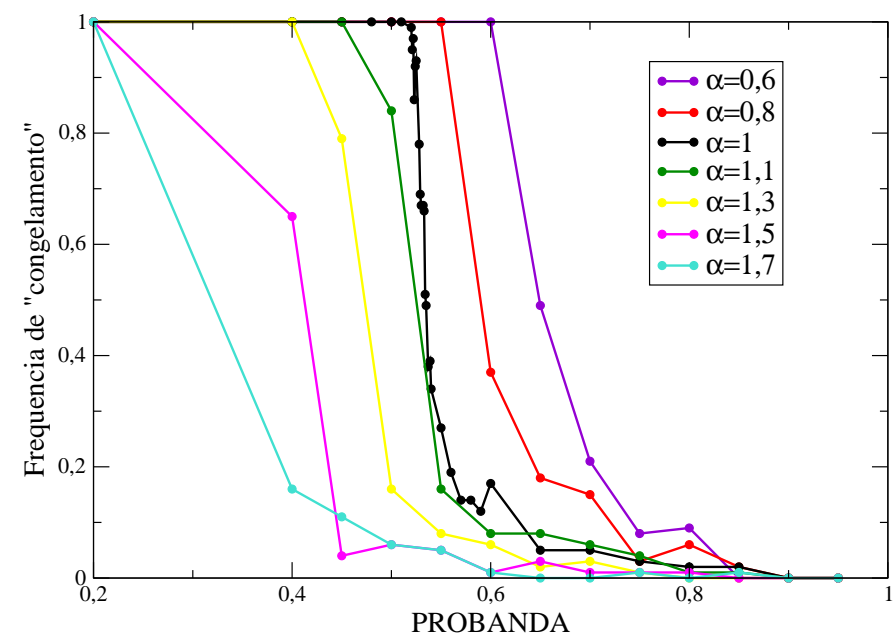

Figura 4.49: Frequência de congelamento Freq como função de PROBANDA, para diversos valores de $\alpha$. Adotou-se a função $L R_{\text {constante. Observa-se que o }}$ sistema continua apresentando uma transição de fase quando $\alpha \leq 2.0$ (Freq=1,0 para $\alpha=2,0$ e PROBANDA $=0,2)$.

\footnotetext{
4 em uma simulação com $\alpha=2.0$ a frequência de "congelamento" ainda é 1 quando PROBANDA $=0,2$. Não se obteve pontos suficientes, para esse valor de $\alpha$, para acrescentar o gráfico de $\alpha=0,2$ na figura 4.49 .
} 


\subsubsection{Resultados experimentais}

Seguem, em caráter ilustrativo, algumas micrografias gentilmente cedidas pelo prof. Franscisco Bosco e pela estudante Telma Nascimento, que desenvolve seu doutorado no Laboratório de Biofísica e Imuno e Parasitologia da Universidade Federal de São Paulo (Escola Paulista de Medicina). Seu doutorado tem o objetivo de isolar e caracterizar células tronco tumorais em linhagens de melanoma [1].

As micrografias exibidas mostram células de melanoma de camundongo cultivadas in vitro. Verifica-se que muitas delas apresentam comportamento de célula tronco e um possível início de diferenciação para a linhagem melanocítica pelo aumento da pigmentação. As células mais escuras dessas imagens devem ser comparadas portanto com as células coloridas com vermelho nas imagens resultantes da simulação. Observa-se que o aspecto arredondado e compacto do tumor, assim como a distribuição das células com características de células tronco estão de acordo, qualitativamente, com os resultados obtidos com as simulações do modelo proposto. 


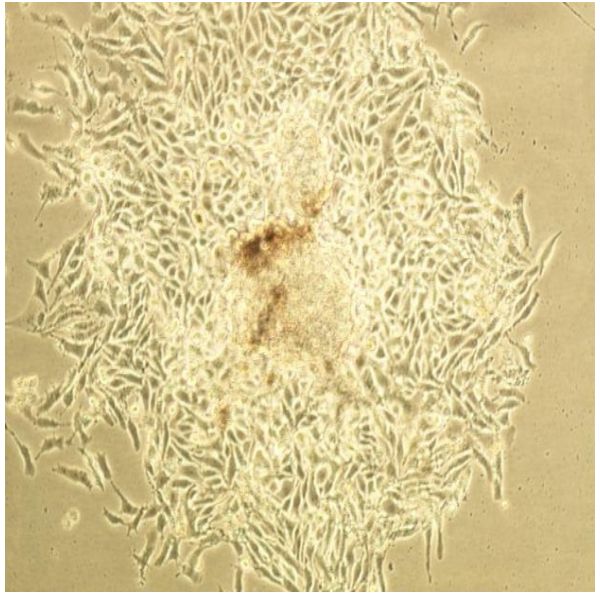

(a) Micrografia 1

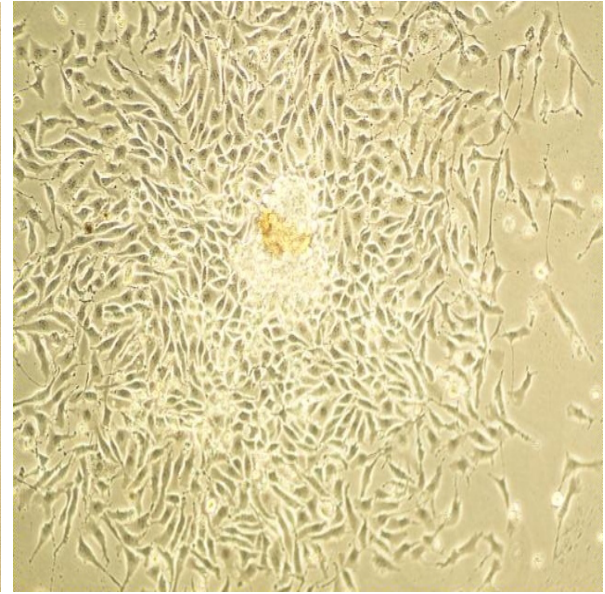

(b) Micrografia 2

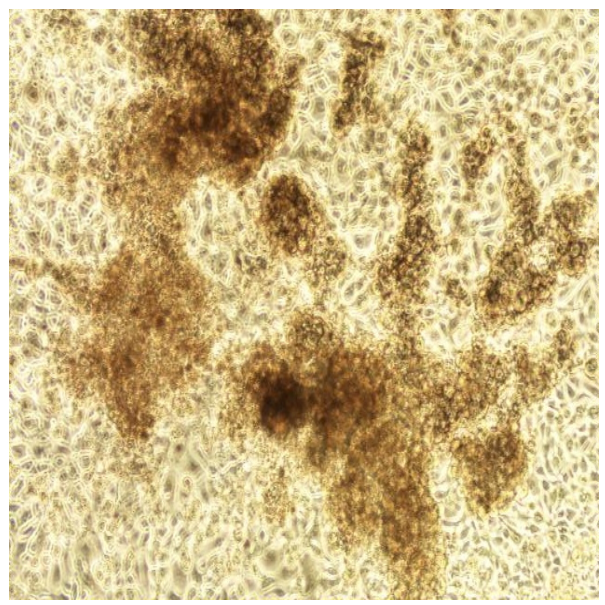

(c) Micrografia 3

Figura 4.50: Micrografias exibindo culturas de células de melanoma de camundongo. Constatou-se experimentalmente, através do aumento de pigmentação, nessas linhagens de células, a existência de uma subpopulação de células com características de célula tronco. As micrografias mostram essas células com coloração mais escura, as de coloração mais clara são células do estroma. Na figura (c), é visto um nicho maior de células do tipo tronco. 


\section{Capítulo 5}

\section{Considerações Finais}

A proposta inicial desse projeto de pesquisa foi tentar desenvolver um modelo numérico de crescimento tumoral que levasse em conta a presença de células com características de células tronco. Essa células podem tanto reproduzir-se dando origem à uma célula filha igual a ela, fenômeno conhecido como auto renovação, como podem originar células que tem o poder de, ao se reproduzir, diferenciar-se em um outro tipo celular, fenômeno conhecido como diferenciação; além disso, elas eventualmente podem mover-se. Investigar o papel das regras locais propostas para a reprodução e difusão e o possível efeito sobre o aspecto macroscópico dos tumores foram os objetivos desse trabalho.

As regras locais para a reprodução, definidas através dos parâme tros $M I N$ e $M A X$ das células, refletem a interação da célula com o microambiente em seu entorno. Observou-se que, independente dos perfis adotados para a função LR, o comportamento do número de células com o tempo $(\log (N) \times \log (t))$ é sempre o mesmo: passado um período transiente, estabelece-se um regime que cresce como uma lei de potência. Essa parece ser uma assinatura do modelo. 
Apesar do aspecto morfológico obtido nas simulações do modelo proposto assemelharem-se qualitativamente ao observado em [33], a curva de crescimento não é ajustada por uma gompertziana (em [34],vê-se que as curvas obtidas são ajustadas por gompertzianas). Entretanto, como visto em [7] e [32], há discordância sobre o tipo de mecanismo que governa o crescimento tumoral. No modelo proposto, também, não há morte espontânea das células da fronteira, uma vez que se simulou o crescimento de tumores in vitro, que ocorre em um meio com abundância de nutrientes e que não opõe resistência ao crescimento do tumor.

Os resultados obtidos com as simulações na condição estacionária permitiram ainda verificar a importância do papel da motilidade das células tipo 2 na evolução dos tumores e associá-la a uma possível transição de fase. Essa transição representa a característica mais importante desse modelo, uma vez que aponta para a existência de um estado mais propício à ocorrência de metastáse (estado metastático).

Por se tratar de um novo modelo, que considera uma hipótese até então não considerada nos modelos numéricos existentes na literatura (a existência de células tronco em tumores), inúmeras possibilidades de pesquisa se abrem como: a possibilidade da inclusão de difusão de nutrientes, assim como a implementação de rotinas que calculem a rugosidade, dimensão fractal da borda do tumor e número de células tipo 2 presentes na borda.

Considera-se que o principal trabalho dessa dissertação foi o desenvolvimento do modelo, não tendo sido possível, por falta de tempo, explorar de forma mais detalhada e cuidadosa todos os seus resultados. Esse estudo foi deixado para uma etapa posterior do trabalho. No entanto, os resultados preliminares obtidos são bastante promissores. 


\section{Referências Bibliográficas}

[1] Nascimento, T. L. ; Calió, M. L. ; Carriço, J. W. ; Porcionatto, M. A. ; Hirata, S. ; Antônio- Bertoncini, C. R. ; Bosco, F. ; Ferreira, A. T. Isolation, characterization and analysis of a subpopulation of tumor stem cell lineages melanoma and melanocytes and its correlation with fractality submitted for publication.

[2] Martins, M. L. ; Ferreira Jr., S. C. ; Vilela, M. J. Multiscale models for the growth of avascular tumors Physics of Life reviews 4, 128-156 (2007).

[3] Roose, T. ; Chapman, S. J. ; Maini, P. K. Mathematical Models of Avascular Tumor Growth. Society for Industrial and Applied Mathematics 49, 179-208 (2007).

[4] Edited by Luigi Preziosi. Cancer Modelling and Simulation. Chapman and Hall/CRC Mathematical Biology and Medicine Series (2003).

[5] Knewitz, M. Um modelo para investigação do crescimento e da morfologia de tumores. Dissertação de Mestrado, Programa Interdisciplinar de Pós Graduação em Computação Aplicada, Universidade do Vale do Rio dos Sinos (UNISINOS) (2002). 
[6] Galvão, V. M. Um modelo para a neoplasia utilizando redes complexas Dissertação de Mestrado, Instituto de Física, Universidade Federal da Bahia (2006).

[7] Brú, A. ; Pastor, J. M. ; Fernaud, I. ; Melle, S. ; Brú, I. Super-Rough Dynamics on tumor growth. Phys. Rev. Lett 81, 4008-40011 (1998).

[8] DeVitta Jr., V. T. ; Hellman, S. ; Rosenberg, S. A. Principles and Practice of Oncology. Lippincott Williams and Wilkins (2001).

[9] Fidler, I. J. The pathogenesis of cancer metastasis: the 'seed and soil' hypothesis revisited. Nature 3, 1-6 (2003).

[10] http://www1.inca.gov.br (Setembro/2009).

[11] http://www.cancercenterofri.org/melanoma.html(Setembro/2009).

[12] http://melanoma.blogsome.com/2006/05/31/moleexpertmicro-software/ (Outubro/2009).

[13] http://www.skinintegrity.com.au/moleMaxVSDigitalCamera.htm (Outubro/2009).

[14] Edited by Stewart, S. Stem Cells Handbook. Humana Press (2004).

[15] Houghton, J. ; Morozov, A. ; Smirnova, I. ; Wang, T. C. Stem cells and cancer. Seminars in Cancer Biology 17, 191203 (2007).

[16] Clarke, M. F. ; Becker, M. W. O potencial maligno das célulastronco. Scientific American Brasil 30, 41-49 (2009). 
[17] Reya, T. ; Morrison, S. J. ; Clarke, M. F. ; Weissman, I. L. Stem cells, cancer, and cancer stem cells. Nature 414, 105-111 (2001).

[18] Pardal, R. ; Clarke, M. F. ; Morrison, S. J. Applying the principles of stem-cell biology to cancer. Nature 3, 895-902 (2003).

[19] Rehen, S. ; Paulsen, B. Células-tronco: o que são? Para que servem? Vieira e Lent (2007).

[20] http://www.nationalacademies.org/stemcells

(Setembro/2009).

[21] http://stemcells.nih.gov/info (Setembro/2009).

[22] http://www.gatmo.org.br (Setembro/2009).

[23] Yun, K. ; Tennent, B. Cancer stem cells. Drug Discovery Today: Disease Models. 4, 47-52 (2008).

[24] Zhao, R. C. ; Zhu, Y. S. ; Shi, Y. New hope for cancer treatment: Exploring the the distinction between normal adult stem cells and cancer stem cells. Pharmacology and Therapeutics 119, 74-82 (2008).

[25] Wicha, M. S. ; Liu, S. ; Dontu, G. Cancer stem cells: an old idea- A paradigm shift. Cancer Res 66, 1883-1890 (2006).

[26] Sales, K. M. ; Winslet, M. C. ; Seifalian, A. M. Stem cells and cancer: an overview. Stem Cell Rev 3, 249-255 (2007).

[27] Reis, A. N. ; Mombach, J. C. M. ; Walter, M. ; Ávila, L. F. The interplay between cell adhesion and environment rigidity in the morphology of tumors. Physica A 322, 546-554 (2003). 
[28] Menchón, S. A. ; Condat, C. A. Cancer growth: Predictions of a realistic model. Physical Review E 78, 22901-1-22901-4 (2008).

[29] Smolle, J. ; Soyer, H. P.; Smolle-Juettner F. M.; Stettner, H.; Kerl, H. Computer Simulation of Tumor Cell Motility and Proliferation Path. Res. Pract. 186, 467-472 (1990).

[30] Smolle, J.; Stettner, H. Computer Simulation of Tumour Cell Invasion by a Stochastic Growth Model. J. Theor. Biol. 160, 63-72 (1993).

[31] Smolle, J.; Smolle-Juettner F. M.; Stettner, H.; Kerl, H. Relationship of Tumor cell Motility and Morphologic Patterns. The American Journal of Dermatopathology 14, 231-237 (1992).

[32] Brú, A. ; Albertos, S. ; Subiza, J. L. ; García-Asenjo, J. L. ; Brú, I. The Universal dynamics of Tumor Growth. Biophysical Journal 85, 2948-2961 (2003).

[33] Ferreira Junior, S. C.; Martins, M. L.; Vilela, M. J. A growth model for primary cancer Physica A 261, 569-580 (1998).

[34] Ferreira Junior, S. C.; Martins, M. L.; Vilela, M. J. A growth model for primary cancer (II). New rules, progress curves and morphology transitions. Physica A 261, 569-580 (1999).

[35] Press, W. H.; Teukolsky, S. A.; Vetterling, W. T.; Flannery, B. P. Numerical Recipes in C: The Art of Scientific Computing. Cambridge University Press (1992).

[36] Documentação do Cluster Abax. http://abax.if.usp.br (Abril/2009). 
[37] Eden, M. in J. Neyman (Ed.) Proceedings of 4th Berkeley Symp. On Mathematical Statistics and Probability. vol. IV : Biology and Problems of Health. University of California Press 223 (1961).

[38] Dickman, A. G.; Dickman, R.; Barbosa, F. A. Transições de fase sem termodinâmica. Revista Brasileira de Ensino de Física 28, 23-33 (2006).

[39] Braga, G. A.; Sanchis, R.; Schieber, T. A. Critical Percolation on a Bethe Lattice Revisited. Society for Industrial and Applied Mathematics 47, 1-17 (2005).

[40] Oliveira, M. M.; Braga, G. A. O fenômeno de transição de fase no modelo de percolação de elos em $d$ dimensões. Revista Brasileira de Ensino de Física 24, 448-454 (2002).

[41] Essam, J. W. Percolation Theory. Rep. Prog. Phys. 43 (1980).

[42] Huntly, B. J. P. ; Gilliland, D. G. Leukaemia stem cells and the evolution of cancer-stem-cell research. Nature 5, 311-321 (2005).

[43] Brú, A. ; Herrero, M. A. From the Physical Laws of Tumor Growth to Modelling Cancer Processes. Mathematical Models and Methods in Applied Sciences 16, 1199-1218 (2005).

[44] Brú, A. ; Casero, D. ; Franciscis, S. ; Herrero, M. A. Fractal analysis and tumour growth. Mathematical And Computer Modelling 47, 546-559 (2008).

[45] Barabasi, A. L. ; Stanley, H. E. Fractal Concepts in Surface Growth Cambridge University Press (1995). 